\title{
SEXTO CICLO DE SELEÇÃO DIVERGENTE PARA TAMANHO DO PENDÃO E ALTURA DE ESPIGA NA POPULAÇÃO DE MILHO (Zea mays L.) ESALQ PB-1
}

\author{
AUSTECLÍNIO LOPES DE FARIAS NETO \\ Engenheiro Agrônomo
}

Orientador: Prof. Dr. José Branco de Miranda Filho

Dissertação apresentada à Escola Superior de Agricultura "Luiz de Queiroz", da Universidade de São Paulo, para obtenção do título de Mestre em Agronomia, Área de concentração : Genética e Melhoramento de Plantas.

P I R A C I C A B A

Estado de São Paulo - Brasil

Março - 1995 


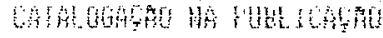

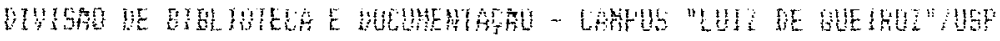

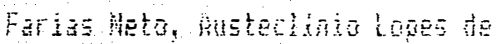

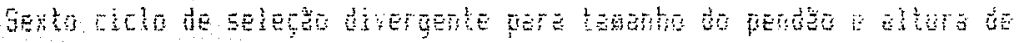

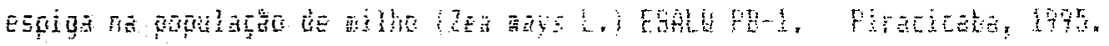
tho . Blus.

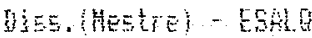

Tibloughas

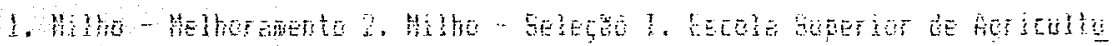

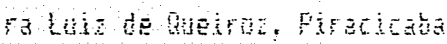

(1) but 


\title{
SEXTO CiClO de SELEÇÃO DiVERGENTE PARA TAMANHO dO PENDÃO E ALTURA de ESPIGA NA POPULAÇÃO DE MILHO (Zea mays L.) ESALQ PB-1
}

\author{
Austeclínio Lopes de Farias Neto
}

Aprovado em 18/04/1995

Comissão julgadora

Prof. Dr. José Branco de Miranda Filho

ESALQ/USP

Dr. Manoel Xavier dos Santos

EMBRAPA/CNPMS

Dr. Luciano Lourenço Nass

EMBRAPA/CENARGEN

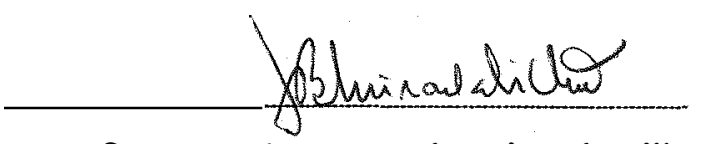

Prof. Dr. José Branco de Miranda Filho

Orientador 
Às minhas irmãs.

OFEREÇO.

Aos meus pais.

DEDICO. 


\section{AGRADECIMENTOS}

- À ninha familia, que sempre me apoiou durante toda a vida.

-À Carmen Paes Cavalcanti, pelo estímulo e apoio transmitidos.

- Ao Prof. Dr José Branco de Miranda Filho, pela orientação na condução deste trabalho.

- Aos professores do Departamento de Genética da ESALQ pelos ensinamentos transmitidos e aos funcionários pela colaboração nos trabalhos.

- À Empresa Brasileira de Pesquisa Agropecuária (EMBRAPA) em especial ao Centro de Pesquisa Agropecuária dos Cerrados (CPAC), pela oportunidade deste treinamento.

- Aos funcionários Antônio Miotto, Marcos Cella e Valdomiro dos Santos pela presteza e colaboração na condução dos experimentos de tese.

- Aos colegas Cláudio Takao Karia, Luciano Lourenço Nass e Raimundo Nonato Vieira da Cunha pela amizade e pela ajuda e sugestões apresentadas. 
ÍNDICE

PÁGINA

LISTA DE TABELAS ................................................................. vi

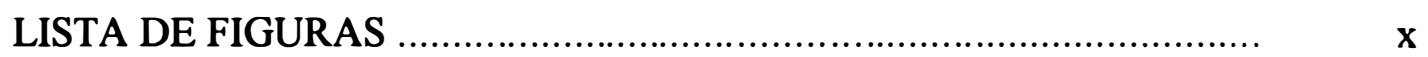

RESUMO

SUMMARY

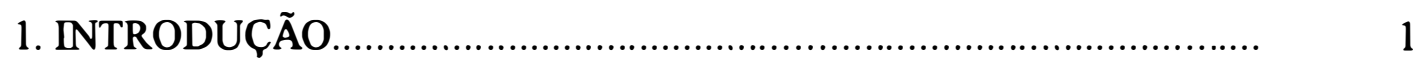

2. REVISÃO DE LITERATURA ………….................................... 3

2.1. Seleção Divergente.................................................................. 3

2.2. Parâmetros Genéticos.............................................................. 5

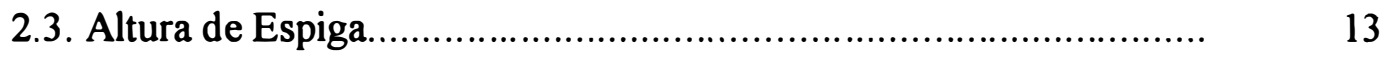

2.4. Tamanho do Pendão............................................................. 18

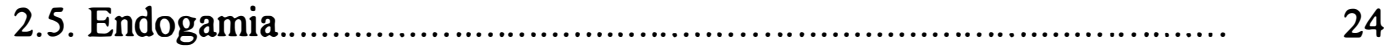

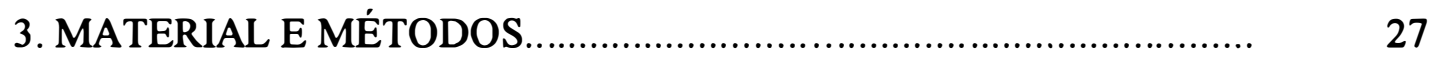

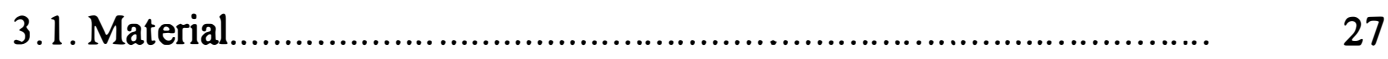

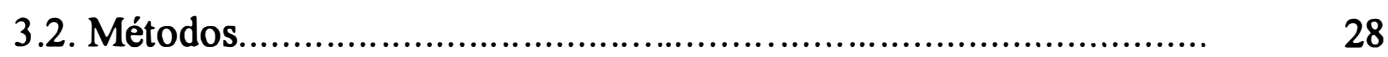

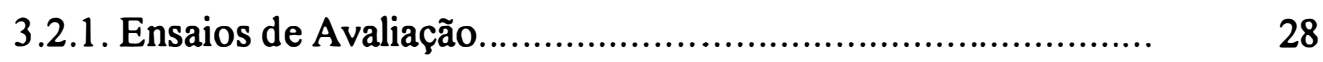

3.2.2. Análises Estatística dos Dados............................................ $\quad 30$

3.2.2.1. Análises de Variância............................................. $\quad 30$

3.2.2.2. Estimativas dos Parâmetros Genéticos...................... 32

3.2.2.3. Covariâncias e Correlações........................................ 34

4. RESULTADOS E DISCUSSÃO.....................................................

4.1. Médias Populacionais............................................................. 36

4.2. Análises de Variância ............................................................... 40

4.3. Parâmetros Genéticos............................................................. $\quad 42$ 
4.3.1. Altura de Espiga.................................................... 44

4.3.2. Caracteres do Pendão................................................ 45

4.3.3. Peso de Espigas....................................................... 47

4.4. Correlações entre Caracteres................................................ 53

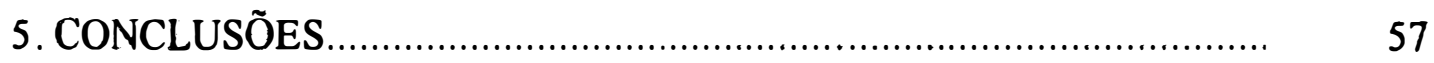

REFERÊNCIAS BIBLIOGRÁFICAS ...................................... 59

TABELAS ........................................................................... $\quad 78$

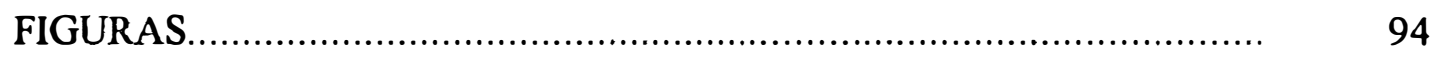




\section{LISTA DE TABELAS}

TABELA

01 Progressos em ganho/ciclo (Gs\%) obtidos por seleção com progênies de irmãos germanos ao nivel intrapopulacional para produção de grãos em populações de milho.

02 Resumo das estimativas de parâmetros genéticos para altura de planta e altura de espiga obtidas por vários autores em populações de milho nacionais e estrangeiras. Dados compilados por MORAES (1989).

03 Estimativas de parâmetros genéticos para o caráter número de ramificações do pendão em milho obtidas por diversos autores.

04 Resumo de estimativas de correlações genéticas aditivas $\left(r_{A}\right)$ e correlações fenotípicas ( $\mathrm{rf}$ ) ao nível de média de famílias envolvendo o caráter número de ramificações do pendão com os caracteres altura de planta (AP), altura de espigas (AE) e peso de grãos obtidas por diversos autores.

05 Esperança matemática dos quadrados médios (QM) para dados de médias ou totais de parcelas, com base na análise agrupada por local.

06 Esperança matemática dos produtos médios obtidos na análise de covariância segundo o delineamento de blocos casualizados.

07 Médias populacionais obtidas por local para os caracteres altura de espiga (AE), altura de planta (AP), número de ramificações do pendão (NR) comprimento do pendão ( $\mathrm{CP})$, peso do pendão (PP) e peso de espigas (PE). 
08 Médias populacionais obtidas no quinto ciclo (C5) e sexto ciclo (C6) e diferença relativa (DR\%) entre as subpopulações divergentes para os caracteres altura de espiga (AE), altura de planta (AP), número de ramificações do pendão (NR), peso de espigas $(\mathrm{PE})$, comprimento do pendão $(\mathrm{CP})$ e peso do pendão (PP).

09 Estimativas de depressão por endogamia (\%) após uma geração de autofecundação para os caracteres altura de espiga (AE), altura de planta (AP), número de ramificações do pendão (NR), comprimento do pendão (CP) e peso do pendão (PP). Piracicaba-SP,1992/93.

10 Quadrados médios e CVe obtidos das análises agrupadas por local dos caracteres altura de espiga (AE), altura de planta (AP), número de ramificações do pendão (NR), peso de espigas (PE), comprimento do pendão (CP) e peso do pendão (PP). Piracicaba-SP, 1992/93.

11 Quadrados médios e CVe obtidos das análises agrupadas por local dos caracteres altura de espiga (AE), altura de planta (AP) e número de ramificações do pendão (NR). Rio Verde-GO, 1992/93.

12 Quadrados médios obtidos da análise conjunta de experimentos para os caracteres altura de espiga (AE), altura de planta (AP), número de ramificações do pendão (NR), envolvendo as localidades de Piracicaba-SP e Rio Verde-GO, 1992/93. Subpopulação R+.

13 Quadrados médios obtidos da análise conjunta de experimentos para os caracteres altura de espiga (AE), altura de planta (AP), número de ramificações do pendão (NR), envolvendo as localidades de Piracicaba-SP e Rio Verde-SP, 1992/93. Subpopulação R-. 
14 Quadrados médios obtidos da análise conjunta de experimentos para os caracteres altura de espiga (AE), altura de planta (AP), número de ramificações do pendão (NR), envolvendo as localidades de Piracicaba-SP e Rio Verde-GO, 1992/93. Subpopulação E+.

15 Quadrados médios obtidos da análise conjunta de experimentos para os caracteres altura de espiga (AE), altura de planta (AP), número de ramificações do pendão (NR), envolvendo as localidades de Piracicaba-SP e Rio Verde-GO, 1992/93. Subpopulação E-.

16 Quadrados médios e CVe obtidos das análises agrupadas conjuntas para os caracteres altura de espiga (AE), altura de planta (AP) e número de ramificações do pendão (NR).

17 Estimativas de variâncias fenotídicas $\left(\sigma_{F}^{2}\right)$. variâncias genéticas $\left(\sigma_{G}^{2}\right)$, e variâncias genéticas aditivas $\left(\sigma_{A}^{2}\right)$, obtidas ao nível de médias através das análises agrupadas por local dos caracteres altura de espiga (AE), altura de planta (AP), número de ramificações do pendão (NR), peso de espigas (PE), comprimento de pendão (CP) e peso de pendão (PP). Piracicaba-SP, 1992/93.

18 Estimativas de variâncias fenotípicas $\left(\sigma_{F}^{2}\right)$, variâncias genéticas $\left(\sigma_{G}^{2}\right)$, e variâncias genéticas aditivas $\left(\sigma_{A}^{2}\right)$, obtidas ao nível de médias através das análises agrupadas por local dos caracteres altura de espiga (AE), altura de planta (AP) e número de ramificações do pendão (NR). Rio Verde-GO, 1992/93.

19 Estimativas de herdabilidades $\left(\mathrm{h}^{2} \mathrm{~m}\right)$ ao nível de médias, obtidas das análises agrupadas por populações e por local (superior Piracicaba, inferior Rio Verde) para os caracteres altura de espiga (AE), altura de planta (AP), número de ramificações do pendão (NR), peso de espiga (PE) peso de espigas (PE), comprimento de pendão (CP) e peso de pendão (PP). 1992/93 
20 Estimativas do coeficiente de variação genético $(\mathrm{CVg} \%)$ e do indice de variação (b), obtidas por população e por local para os caracteres altura de espiga ( $\mathrm{AE})$, altura de planta ( $\mathrm{AP})$, número de ramificações do pendão (NR), peso de espiga (PE) peso de espiga (PE), comprimento de pendão $(\mathrm{CP})$ e peso de pendão (PP). 1992/93.

21 Estimativas do coeficiente de variação genético $(\mathrm{CVg} \%)$ e do índice de variação (b), obtidas pela média dos dois locais para os caracteres altura de espiga (AE), altura de planta (AP), número de ramificações do pendão (NR), peso de espigas (PE). 1992/93.

22 Estimativas dos coeficientes de correlạções genéticas $\left(r_{\mathrm{g}}\right)$ e fenotípicas (rf) obtidas por população e por local. 1992/93. 
LISTA DE FIGURAS

FIGURA

PÁGINA

01 Subpopulações divergentes para maior $(\mathrm{AE}+)$ e menor (AE-) altura de espiga.

02 Subpopulą̧ões divergentes para maior $(R+)$ e menor (R-) número de ramificaões do pendão.

03 Subpopulą̧ões divergentes para maior $(R+)$ e menor (R-) número de ramificações do pendão.

04 Subpopulações S 1 (AF-centro) e subpopulações S0 ( laterais ).

05 Distribuição de freqüências de médias e valores de média populacional (M), variância (var) e intervalo de variação (I.V) para o caráter $\mathrm{AE}$ nas subpopulą̧ões divergentes para NR.

06 Distribuição de freqüências de médias e valores de média populacional (M), variância (var) e intervalo de variação (I.V) para o caráter $\mathrm{AE}$ nas subpopulações divergentes para $\mathrm{AE}$.

07 Distribuição de freqüências de médias e valores de média 99 populacional (M), variância (var) e intervalo de variação (I.V) para o caráter $A E$ nas subpopulações $S_{1}$ divergentes para NR.

08 Distribuição de freqüências de médias e valores de média 100 populacional (M), variância (var) e intervalo de variação (I.V) para o caráter AP nas subpopulações divergentes para NR.

09 Distribuição de freqüências de médias e valores de média 101 populacional (M), variância (var) e intervalo de variação (I.V) para o caráter AP nas subpopulações divergentes para $\mathrm{AE}$. 
10 Distribuição de freqüências de médias e valores de média 102 populacional (M), variância (var) e intervalo de variação (I.V) para o caráter AP nas subpopulações $S_{1}$ divergentes para NR.

11 Distribuição de freqüências de médias e valores de média 103 populacional (M), variância (var) e intervalo de variação (I.V) para o caráter NR nas subpopulações divergentes para NR.

12 Distribuição de freqüências de médias e valores de média 104 populacional (M), variância (var) e intervalo de variação (I.V) para o caráter NR nas subpopulações divergentes para AE.

13 Distribuição de freqüências de médias e valores de média 105 populacional (M), variância (var) e intervalo de variação (I.V) para o caráter NR nas subpopulações $S_{1}$ divergentes para NR.

14 Distribuição de freqüências de médias e valores de média populacional (M), variância (var) e intervalo de variação (I.V) para o caráter PE nas subpopulações divergentes para NR e AE.

15 Distribuição de freqüências de médias e valores de média 107 populacional (M), variância (var) e intervalo de variação (I.V) para o caráter $\mathrm{CP}$ nas subpopulações divergentes para NR e AE.

16 Distribuição de freqüências de médias e valores de média 108 populacional (M), variância (var) e intervalo de variação (I.V) para o caráter PP nas subpopulações divergentes para NR e AE. 


\title{
SEXTO CiClo de SELEÇÃo divergente PARA TAMANHO dO PENDÃO E ALTURA dE ESPIGA NA POPULAÇÃO DE MILHO (Zea mays L.) ESALQ PB-1
}

\author{
Autor: AUSTECLÍNIO LOPES DE FARIAS NETO \\ Orientador: PROF. Dr JOSÉ BRANCO DE MIRANDA FILHO
}

\section{RESUMO}

No presente trabalho foram estudadas progênies de irmãos germanos e progênies $\mathbf{S}_{1}$ obtidas através de seis ciclos de seleção divergente para altura de espiga ( $\mathrm{AE}$ ) e tamanho do pendão (NR) aplicados à população ESALQ PB-1. No primeiro ciclo a seleção foi praticada entre familias de meios irmãos e nos quatro ciclos posteriores foi praticada a seleção massal com cruzamentos planta a planta, sendo no sexto ciclo obtidas também progênies oriundas de autofecundação nas linhas divergentes para NR. Os caracteres avaliados no presente ciclo foram altura de espiga (AE), altura de planta $(A P)$, número de ramificações do pendão (NR), comprimento do pendão (CP), peso do pendão (PP) e peso de espigas (PE). As seis subpopulações (linhas de seleção para altura de espiga, E+ e E-, linhas de seleção para número de ramificações do pendão, $R+$ e R-e linhas de seleção para número de ramificações do pendão obtidas por autofecundação, $\mathrm{R}_{\mathrm{s}}$ e R-s ) foram avaliadas nas localidades de Piracicaba-SP e Rio Verde-GO, com os ensaios obedecendo a um delineamento de blocos casualizados com três repetições por local. Os parâmetros estimados foram as médias populacionais, variância genética entre progênies, variância genética aditiva, herdabilidade ao nivel de médias, coeficiente de variação genético, indice de variação genético e correlações entre caracteres.

Os resultados obtidos mostraram que a seleção foi efetiva na ampliação das diferenças entre as médias dos caracteres nas subpopulações divergentes, sendo que as maiores diferenças foram observadas para os caracteres tomados como base para a seleção (AE e NR) nas respectivas linhas de seleção. Os parâmetros genéticos estimados indicaram, à exceção de PP, a presença de suficiente variabilidade genética para a obtenção de progressos em futuras seleções para todos os caracteres, principalmente para NR. Esses parâmetros mostraram-se superiores em Rio Verde em consequência da melhor precisão experimental verificada nesta localidade em relação à Piracicaba. 
Foram obtidas nas subpopulações autofecundadas $(\mathrm{R}+\mathrm{s} 1$ e $\mathrm{R}-\mathrm{sl})$, estimativas da variância genética entre progênies superiores às suas correspondentes $\mathrm{S} 0$, à exceção do caráter $\mathrm{AE}$ em $\mathrm{R}+\mathrm{e} \mathrm{R}$-.

As interações de genótipos por ambiente de uma maneira geral, mostraramse não significativas pelo teste $F$ e o efeito de local foi bastante acentuado para NR sendo para esse caráter verificadas médias superiores em Rio Verde em relação à Piracicaba.

As correlações entre AP e AE apresentaram-se as mais altas entre todas as correlações estimadas, não mostrando mudanças ao longo dos ciclos de seleção. Em função da baixa variabilidade presente nas subpopulações avaliadas para o caráter PP, as correlações estimadas entre esse caráter e os demais mostraram-se incossistentes e portanto de dificil interpretação.

Com o objetivo de se avaliar os efeitos dos seis ciclos de seleção na variabilidade genética dos caracteres avaliados, as subpopulações $\mathrm{R}+, \mathrm{R}-, \mathrm{E}+\mathrm{e} \mathrm{E}-$ foram comparadas com a população original ESALQ PB-1, através do índice de variação genético $b$. Os resultados indicaram uma queda acentuada na variabilidade para $o$ caráter PE em todas as subpopulações, e para AE nas linhas de seleção para esse caráter, o mesmo acontecendo para AP em consequência da estreita associação entre os dois caracteres. Para os demais caracteres avaliados não foram observadas reduções significativas na variabilidade genética. 


\title{
SIXTH CYCLE OF DIVERGENT SELECTION FOR TASSEL SIZE \\ AND EAR PLACEMENT ON MAIZE (Zea mays L.) \\ POPULATION ESALQ PB-1
}

\author{
Author: AUSTECLÍNIO LOPES DE FARIAS NETO \\ Adviser: PROF. Dr JOSÉ BRANCO DE MIRANDA FILHO
}

\section{SUMMARY}

The present work was based on the evaluation of full-sib families obtained after six cycles of divergent selection for tassel size (NR) and ear placement (AE). In the first cycle the selection was based on half-sib families and the next four cycles mass selection for both sexes was used. In the sixth cycle $S_{1}$ progenies were also obtained from the lines of selection for tassel size. In the sixth cycle the following traits were analised: ear height (AE), plant height (AP), tassel branch number (NR), tassel length (CP), tassel weight (PP) and ear yield (PE). The six sub-populations (lines of selection for ear placement, $\mathrm{E}+$ and E-, lines of selection for number of tassel branches, $\mathrm{R}+$ and $\mathrm{R}-$ and $\mathrm{S}_{1}$ progenies obtained from R+ and R-) were evaluated at Piracicaba-SP and Rio Verde-GO following the randomized complete design with three replications. The estimated parameters were population means, variance between progenies, heritability (broad sense), coeficient of genetic variation, genetic variation index and correlations between characteres.

The results showed that selection was efficient for the amplification of differences among population means of divergent sub-populations, and the greater diferences were observed for the character used for selection ( $A E$ and NR) in the respectives lines of selection. The sub-populations exibited for all characters, except PP, sufficient genetic variability to obtain progress in future selection. The sub-populations Eand $\mathrm{R}$ - are the more suitable to be explored in a breeding program. Estimates of variance between progenies $\left(\sigma_{G}^{2}\right)$, additive genetic variance $\left(\sigma_{A}^{2}\right)$ and heritability $\left(\mathrm{h}^{2}\right)$, were higher in Rio Verde, in consequence of the better experimental precision obtained in that local. 
In general, estimates of genetic variance among progenies were higher for $S_{1}$ progenies in relation to FS progenies, except for the traits $A E$ in $R+$ and $R-$.

The correlations between $\mathrm{AP}$ and $\mathrm{AE}$ were the highest among all the correlations estudied, and did not change along the cycles of selection. Because the low variability exibited for PP the correlations between this trait and the others showed inconsistences and difficult to be interpreted.

With the objective of evaluating the effects of the selection on genetic variability, the sub-populations $\mathrm{R}+, \mathrm{R}-, \mathrm{E}+$ and $\mathrm{E}$ - were compared for the original population ESALQ PB-1, using the genetic variation index. The results indicated a great decrease on variability of $\mathrm{PE}$ in all sub-populations and of $\mathrm{AE}$ in $\mathrm{E}+$ and $\mathrm{E}-$. It was also found a great decrease on variability for $\mathrm{AP}$ in $\mathrm{E}+$ and $\mathrm{E}$ - due to the high correlations observed between this character and $\mathrm{AE}$. For the other traits no significant changes on genetic variability were observed. 


\section{INTRODUÇÃO}

Dentre as espécies cultivadas, o milho (Zea mays L.) é uma das que mais sofreu processos de melhoramento, sendo que as técnicas convencionais utilizadas deram ênfase principalmente à produção de grãos. $\mathrm{O}$ trabalho de melhoramento, assim como o aprimoramento das práticas culturais, contribuiram e contribuem substancialmente para 0 aumento da produção de grãos dessa espécie.

Mais recentemente, as técnicas convencionais vem sendo auxiliadas por aquelas relacionadas à características complementares à produção, que direta ou indiretamente influenciam o rendimento total da cultura. Neste sentido, grande ênfase tem sido dada à arquitetura da planta, visando um melhor aproveitamento da energia solar aumentando a eficiência fotossintética da planta (DONALD, 1968; WITTWER, 1974), assim como minimizando as perdas na colheita. A redução da altura de espiga constitui objetivo importante nos programas de melhoramento, pois além de mais resistentes ao tombamento e ao quebramento do colmo devido à ação do vento (JOSEPHSON \& KINCER, 1977), plantas de menor altura de espiga mostram-se melhor adaptadas à colheita mecânica (PATERNIANI, 1974; MIRANDA FILHO, 1974; SAMPAIO, 1986).

Outro caráter relacionado à eficiência da planta de milho é o tamanho do pendão. Segundo KIESSELBACH (1949), uma planta de milho libera cerca de 25.000 grãos de pólen para cada óvulo fecundado em grão, e que a energia consumida pela planta para a produção de pólen estaria sendo então desperdiçada. ANDERSON (1971), relata que o pendão, pelo controle da produção do ácido Indol-acético, exerce a dominância apical influenciando desse modo a prolificidade. Diante destes fatos MOCK \& PEARCE (1975), sugeriram para a obtenção de uma planta eficiente no aproveitamento da energia sintetizada, uma seleção para pendões menores pois, segundo os autores, essa seria uma das características do ideótipo para a cultura do milho.

A população ESALQ PB-1, objeto deste estudo, foi obtida no Departamento de genética da ESALQ/USP a partir de sete variedades de porte baixo (MIRANDA 
FILHO, 1974), tendo seus parâmetros genéticos relativos a altura de espiga e número de ramificações do pendão estimados por ANDRADE \& MIRANDA FILHO (1980) e GHINI \& MIRANDA FILHO (1979), respectivamente, revelando possuir uma alta variabilidade genética para ambos os caracteres.

A estimação dos parâmetros genéticos do caráter a ser melhorado é de fundamental importância em um programa de melhoramento, pois é através do conhecimento desses parâmetros, em especial da variância genética aditiva, que torna-se possível predizer o progresso com seleção, que por sua vez irá orientar o melhorista na análise e seleção de populações e nos métodos a serem utilizados. As alterações nos parâmetros genéticos de um caráter ao longo dos ciclos de seleção, bem como as relações existentes entre caracteres são outros aspectos importantes a serem avaliados, pois o melhoramento genético é um processo contínuo, e praticado, de uma maneira geral, para vários caracteres simultaneamente.

Tendo em vista a importância do estudo dos aspectos arquitetura de planta e eficiência no aproveitamento da energia sintetizada, aspectos esses relacionados à altura de espiga e número de ramificações do pendão, e o fato de apresentar uma grande possibilidade de sucesso na seleção, a população ESALQ PB-1 foi submetida à seleção para esses caracteres, sendo para isso utilizado o processo de seleção divergente.

No presente trabalho, foram avaliadas progênies de irmãos germanos e progênies $S_{1}$, relativas ao sexto ciclo de seleção divergente, com os seguintes objetivos:

a) Determinar o efeito direto da seleção divergente nos caracteres altura de espiga (AE) e número de ramificações do pendão (NR).

b) Determinar o efeito indireto da seleção divergente para AE e NR sobre os demais caracteres avaliados, quais sejam: altura de planta (AP), comprimento do pendão $(\mathrm{CP})$, peso do pendão (PP) e peso de espigas (PE).

c) Estimar as correlações genéticas e fenotípicas entre os caracteres estudados.

d) Verificar a depressão por endogamia para os caracteres em estudo. 


\section{REVISÃO DE LITERATURA}

\subsection{SELEÇÃO DIVERGENTE}

A seleção divergente vem atuando a tempos na natureza, promovendo a ampliação do número de espécies e da variabilidade genética. Segundo STEBBINS (1970), o aparecimento de novas espécies em plantas de polinização cruzada ocorre através da seleção disruptiva, que resulta da exposição de partes diferentes de uma mesma população a pressões seletivas divergentes, promovendo o aparecimento de diferentes formas adaptativas .

Um exemplo de seleção disruptiva foi realizada por PATERNIANI (1969). O autor utilizou-se das populações de milho "Pérola Piracicaba", que se caracterizava por possuir grãos brancos e endosperma tipo "flint", ou seja, recessivo para cor e homozigoto dominante para tipo de endosperma, e "Doce Amarelo de Cuba", que se apresentava como homozigoto dominante para cor e recessivo para tipo de endosperma. As populações foram cultivadas em áreas contíguas, ocorrendo assim o intercruzamento entre elas, sendo entretanto, praticada uma forte seleção contra o hibrido, explorando o efeito de xenia. Após cinco ciclos de seleção, a porcentagem de híbridos era praticamente nula, chegando-se ao isolamento reprodutivo. $\mathrm{O}$ autor mostrou assim, que a divergência pode acontecer mesmo quando os cruzamentos ocorrem ao acaso.

O processo seletivo tem como objetivos a obtenção de materiais melhorados para serem utilizados para plantio e o estudo da estrutura genética das populações. $\mathbf{O}$ processo de seleção divergente tem a vantagem de dar maiores informações sobre o caráter estudado, pois segundo FALCONER (1960), a resposta medida em duas linhas opostas é duas vezes maior a que se obteria praticando-se seleção em única direção, tendo a vantagem ainda de se diminuir os problemas devido a erros de amostragem e de mudanças ambientais que ocorrem entre as gerações.

Muitas vezes no processo de seleção divergente, a resposta não é igual nas duas direções, apresentando-se de forma assimétrica. Segundo FALCONER (1964), esse 
comportamento tem como causas: 1) diferencial de seleção diferente nas linhas positiva e negativa; 2) assimetria genética devido à presença em maior quantidade de genes dominantes para uma determinada direção (dominância direcional), ou à maior freqüência de genes para uma determinada direção; 3 ) seleção a favor dos heterozigotos em uma das direções; 4) depressão por endogamia, que causa, se o caráter estiver sujeito à depressão, uma diminuição da resposta no sentido positivo e aumento no sentido negativo e 5) efeitos maternos. Outro aspecto a ser observado é que a resposta à seleção não é a mesma através das gerações, apresentando-se de maneira irregular, pois mudamse as freqüências gênicas e conseqüentemente as propriedades genéticas da geração descendente.

Um trabalho clássico utilizando a seleção divergente na cultura do milho foi iniciado por Hopkins em 1896 e ainda continua em andamento. Trata-se da seleção para altos e baixos teores de óleo e proteina na população "Burr's White", sendo conduzida por mais de oitenta gerações e sofrendo várias modificações ao longo do processo seletivo, conforme relatado por DUDLEY et al. (1974). Após sessenta e cinco gerações, as quatro subpopulações foram avaliadas por DUDLEY \& LAMBERT (1969), onde foi observada a presença de suficiente variabilidade genética para se obter ganhos com seleção em todas as subpopulações. Posteriormente, DUDLEY (1977), analisou os materiais após setenta e cinco gerações, observando progressos de $274 \%$ e $95 \%$ em relação à média original, nas linhas de seleção para alto e baixo teor de óleo, respectivamente. Os ganhos para as linhas de alto teor de proteina, foram de $133 \% \mathrm{e}$ baixo teor de proteína, de $78 \%$. Os autores observaram ainda que a exemplo da geração de seleção analisada anteriormente, progressos com seleção poderiam ser obtidos devido à presença de variabilidade genética na população. Mais recentemente, DUDLEY \& LAMBERT (1992), avaliaram as subpopulações após noventa gerações, onde observaram que os ganhos para as subpopulações de baixos teores de óleo e proteína parecem ter atingido um limite. Talvez os baixos teores de óleo $(<1 \%)$ e de proteína (4\%) nessas populações, representem os valores mínimos abaixos dos quais a planta não possa sobreviver. Futuros progressos, no entanto, podem ainda ser obtidos com as subpopulações de alto teor de óleo e proteína.

Devido às vantagens da seleção divergente, seu uso é bastante pronunciado, principalmente objetivando o estudo da estrutura genética de populações para várias características, como capacidade de combinação (PENNY et al., 1962), acamamento (THOMPSON, 1970), enchimento de grãos (HARTUNG, 1984), umidade de grãos 
(CROSS et al., 1987), e absorção de nitrogênio (TEYKER et al., 1989). TORREGROZA (1974), trabalhando com uma variedade sintética de milho, avaliou oito ciclos de seleção massal divergente para prolificidade, obtendo um ganho de $39 \%$ para esse caráter acompanhado de um aumento de produção de $35 \%$. A prolificidade caiu em $10 \%$ na linha negativa sem alterações na produção de grãos. CORTEZ-MENDOZA \& HALLAUER (1979), após dez ciclos de seleção para comprimento de espiga, verificaram um ganho na linha positiva de $15,3 \%$ no comprimento de espiga, duas vezes menor que na linha negativa (30,6\%). Segundo os autores, esta assimetria ocorreu em fiınção de freqüências gênicas desiguais e dominância direcional.

Mais recentemente, ODHIAMBO \& COMPTON (1987), avaliaram vinte ciclos de seleção massal para tamanho de semente. A seleção mostrou-se bastante eficiente, reduzindo o peso de 1000 sementes em 7,21 g/ciclo na linha negativa, acompanhado de uma redução na produção de grãos, e na linha oposta, um aumento de 4,68 g /ciclo, com um aumento de produção. LIMA et al. (1992), praticaram dois ciclos de seleção divergente para tolerância a alumínio na população de milho IAC-Taiuba, avaliando as respostas à seleção através da análise do comprimento de radícula. Os autores observaram que a seleção divergente foi ef etiva na mudança das médias, obtendo um ganho médio para as duas linhas, de $26,1 \%$. O efeito da seleção foi observado também em outros caracteres como produção, altura de planta e altura de espiga, com ganhos de $15,1 \%, 5,6 \%$ e $3,6 \%$, respectivamente, considerando-se também a média das linhas positiva e negativa.

\subsection{PARÂMETROS GENÉTICOS}

A presença de variabilidade genética é um fator fundamental para o sucesso de qualquer programa de melhoramento, pois o progresso com seleção está diretamente relacionado com a quantidade de variação genética presente na população. Segundo HALLAUER \& MIRANDA FILHO (1988), a estimação do progresso com seleção constitui-se em uma das maiores contribuições da genética quantitativa para 0 melhoramento, permitindo a avaliação do potencial de populações e da eficiência relativa dos diversos processos de seleção.

A variação total de um determinado caráter em uma população é descrita estatisticamente pela variância fenotípica, que por sua vez, corresponde à soma das variâncias genética e ambiental. $\mathrm{O}$ conhecimento da variância genética é de suma 
importância, pois irá determinar qual tipo de seleção será mais eficiente, além de orientar o melhorista na escolha da população base para o melhoramento. Foi FISHER (1918), quem primeiro decompôs a variância genética em três componentes : 1) variância genética aditiva, associada aos efeitos médios dos genes; 2) variância genética dominante, associada aos desvios associados às interações intra-alélicas; 3) variância epistática, devido aos desvios associados às interações interalélicas. Porém, foi com os trabalhos de COMSTOCK \& ROBINSON (1948,1952), onde foram apresentados delineamentos estatístico-genéticos, que tornou-se possível a estimação da variância genética em milho. Estes delineamentos baseiam-se, fundamentalmente, segundo HALLAUER \& MIRANDA FILHO (1988), no grau de parentesco entre os indivíduos que constituem as progênies geradas em cruzamentos, e a composição da variância genética está relacionada com o tipo de progênie utilizada e as diferenças entre as quantidades de variância expressas em cada uma. Através dessa metodologia ROBINSON et al. (1955), evidenciaram então a existência em variedades de polinização aberta de milho, de suficiente variabilidade genética para a obtenção de progressos com seleção.

Tais estudos mostraram então, que a hipótese de HULL (1945), a qual sugeria que a variabilidade genética para o caráter produção estava se esgotando devido ao grande número de gerações de seleção, era incorreta, e que o fracasso no aumento da produtividade dos híbridos da época era devido à ineficiência dos processos de seleção, decorrentes de problemas técnicos, tais como: amostragem inadequada, falta de isolamento, etc (GARDNER, 1961 ; LONNQUIST, 1961).

Vários outros estudos ampliaram os trabalhos de FISHER (1918): WRIGHT (1921), incluiu o efeito de endogamia; COCKERHAM (1954), e KEMPTORNE $(1945,1955)$, apresentaram a decomposição da variância hereditária incluindo os efeitos epistáticos, COCKERHAM (1956) e SCHENELL (1963), acrescentaram os efeitos de ligação gênica; COCKERHAM (1963), apresentou diversos modelos para estimação da variância genética e WEIR \& COCKERHAM (1965) e COCKERHAM \& WEIR (1973), apresentaram estudos envolvendo dois locos.

A presença de variabilidade genética em populações de milho tem sido confirmada em diversos trabalhos (LONNQUIST, 1961; MOLL \& ROBINSON, 1966; LONNQUIST, 1977 ; CRISÓSTOMO, 1978 ; SOUZA Jr , 1983 ; SANTOS, 1985; ANDRADE, 1988; HALLAUER \& MIRANDA FILHO, 1988 ; NASS, 1992; ARAÚJO, 1992, entre outros). Esse fato é de grande importância, pois torna possível o 
melhoramento continuo e gradativo e a exploração do potencial genético das populações.

Vários autores têm indicado a variância genética aditiva como o principal componente da variância genética total para diversos caracteres, indicando um predomínio do efeito gênico do tipo aditivo e justificando o emprego de métodos de seleção intrapopulacionais (GOODMAN, 1965; SUBANDI \& COMPTON, 1974; SILVA \& HALLAUER, 1975, entre outros). HALLAUER \& MIRANDA FILHO (1988), realizaram amplo levantamento das estimativas da variância genética aditiva em vários trabalhos e observaram a existência de suficiente variabilidade genética aditiva para diversos parâmetros. Para o caráter produção, os autores evidenciaram que os valores da variância genética aditiva respondiam por $61,2 \%$ da variância genética total, respondendo a variância genética dominante por $38,8 \%$, já que foram negligenciados os efeitos epistáticos e de ligação.

Como ressaltado por SOARES FILHO (1987), embora o conhecimento da magnitude da variância dominante seja importante para a identificação de caracteres cuja expressão fenotípica, a exemplo da produção de grãos, possa ser explorada com base no emprego da heterose, é na variância aditiva que se fundamenta o melhoramento genético. Segundo FALCONER (1964), a variância aditiva, que é a variância dos valores genéticos, é o componente mais importante, uma vez que é a principal causa de semelhança entre parentes e, por conseguinte, o principal determinante das propriedades genéticas da população e da resposta da população à seleção. Ainda segundo o autor, deve-se observar que o conceito de variância aditiva não traz consigo o pressuposto de ação gênica aditiva, pois a mesma pode provir de genes com qualquer grau de dominância ou epistasia, e sua existência não é indicação de que os genes agem aditivamente (não mostram dominância nem epistasia); somente se toda variância genotípica for aditiva, poder-se-á concluir que não haverá dominância nem epistasia. É importante ressaltar ainda, que as magnitudes das variâncias genéticas são influenciadas por muitos fatores como intensidade de seleção, desequilibrio de ligação, taxa de recombinação e variações no ambiente.

Um conceito importante na interpretação de variância genética é o coeficiente de variação genética (CVg), apresentado por VENCOVSKY (1978), o qual permite a avaliação da variação genética existente em relação às respectivas médias populacionais. Segundo o autor, o índice de variação $b$, que é o quociente entre o CVg e o coeficiente de variação experimental (CVe), representa uma informação a mais para o 
melhorista, sendo bastante útil na comparação da variabilidade genética entre diferentes ciclos ou populações.

Com relação à epistasia, segundo HALLAUER \& MIRANDA FILHO (1988), para a estimação deste componente é necessária a utilização de delineamentos complexos e os resultados obtidos não têm sido muito satisfatórios. Os autores esclarecem ainda, que as variâncias epistáticas têm, provavelmente, valores muito menores que as variâncias aditiva e dominante, podendo portanto,serem negligenciadas. Outros autores corroboram com essa idéia como VENCOVSKY (1969) e FEHR (1987), entre outros.

Com o desenvolvimento da genética quantitativa, foi possivel através do conhecimento dos componentes da variância genética, predizer o progresso com seleção, obtendo-se assim bases científicas para o desenvolvimento e evolução dos processos de seleção. Segundo COCKERHAM (1963), existem muitos processos para estimar os componentes da variância. Delineamentos específicos, como os propostos por COMSTOCK \& ROBINSON $(1948,1952)$, bem como delineamentos experimentais de seleção podem ser usados para estimar os componentes da variância (HALLAUER \& MIRANDA FILHO, 1988). Estes últimos são bastante utilizados, pois prestam-se ao melhoramento intrapopulacional propriamente dito e para a estimação dos componentes da variação genética.

No Brasil tem-se utilizado com freqüência progênies de meios irmãos na avaliação do potencial genético de populações. $O$ método de seleção entre e dentro de familias de meios irmãos (PATERNIANI, 1967), apesar da impossibilidade de estimar a variância genética dominante, é bastante útil pois estima a variância genética aditiva no decorrer dos ciclos de seleção, mostrando ao melhorista as alterações que ocorreram na variabilidade genética. Este método pode ser conduzido em um ciclo por ano, onde a seleção é praticada em um só sexo, ou em dois anos, praticando-se seleção entre as progênies nos dois sexos.

Vários autores mostraram a eficiência do método. Dentre os resultados podem ser destacados os trabalhos de WEBELL \& LONNQUIST (1976), PATERNIANI (1967,1968), DARRAH et al. (1972), SEGÓVIA (1976), COMPTON SAWAZAKI (1979) e POMMER \& GERALDI (1983).

RAMALHO (1977), realizou extenso levantamento sobre as estimativas obtidas para parâmetros genéticos e fenotípicos em populações de milho da ESALQ/USP através desse método. $\mathrm{O}$ autor verificou uma estimativa média de 310 
$(\mathrm{g} / \mathrm{pl})^{2}$ para o caráter produção de grãos. Os valores médios obtidos para o coeficiente de herdabilidade $\left(\mathrm{h}^{2}\right)$ e para o coeficiente de variação genética $(\mathrm{CVg})$ foram de $9,67 \%$ e $8,21 \%$, respectivamente. $O$ autor realizou ainda comparações da seleção entre meios irmãos (SPMI) e da seleção entre irmãos germanos (SPIG) ao nível intrapopulacional, baseando-se nos progressos genéticos esperados e observou, de maneira geral, uma superioridade do segundo método (SPIG).

Outro método de seleção bastante utilizado é o de seleção entre famílias de irmãos germanos, proposto por HARLAND (1946). As progênies são obtidas através do cruzamento entre duas plantas, testadas em experimentos com repetições e com base nos resultados, selecionadas as melhores progênies. As sementes remanescentes das progênies selecionadas são recombinadas em lotes isolados, podendo ou não se praticar seleção dentro das progênies. Segundo SOUZA Jr (1983), o mais utilizado atualmente é a seleção apenas entre as progênies.

LONNQUIST (1961), introduziu uma modificação ao esquema original, na qual as progênies de irmãos germanos são avaliadas segundo um esquema em cadeia. Desta maneira uma mesma planta é avaliada com dois genótipos ao invés de apenas um, tendo uma seqüência de cruzamentos $1 \times 2,2 \times 3,3 \times 4, \ldots(n-1) \times n$ e $n \times 1$.

No Brasil, o esquema em cadeia foi avaliado por VALOIS (1982) e VALOIS \& MIRANDA FILHO (1984), e os resultados mostraram a superioridade do esquema usual em relação ao esquema em cadeia. Outros trabalhos mostram a eficiência do método de irmãos germanos. A Tabela 01 apresenta alguns resultados obtidos.

Quando se pratica seleção em uma determinada população, é esperada uma queda na variabilidade genética, reduzindo assim o progresso médio por geração devido, segundo VENCOVSKY (1978), à fixação de alelos favoráveis. De acordo com LERNER (1958), existe uma redução inicial na variabilidade genética com a seleção sendo que, posteriormente, parte desta redução pode ser compensada, pois a permuta genética libera variabilidade potencial. Esse fato foi observado por diversos autores (PATERNIANI, 1967; WEBEL \& LONNQUIST, 1967; PATERNIANI, 1968; SILVA, 1969; CUNHA, 1976). Em programas de seleção recorrente a longo prazo, são esperadas maiores respostas nos ciclos iniciais, e que essas respostas tornem-se progressivamente menos pronunciadas nos ciclos avançados pelo decréscimo da variabilidade da população (GARDNER, 1977). Muitos experimentos têm sido reportados na literatura sobre efeitos da seleção na variabilidade genética em populações. MOLL \& STUBER (1971), levantaram alguns destes trabalhos e observaram que as 
populações estudadas não apresentavam queda significativa na variabilidade genética no decorrer dos ciclos de seleção. STUCKER \& HALLAUER (1992), avaliando o sintético

TABELA 0 1- Progressos em ganho/ciclo (Gs\%) obtidos por seleção com progênies de irmãos germanos ao nível intrapopulacional, para produção de grãos em populações de milho.

\begin{tabular}{lccl}
\hline População & ciclos & Gs \% & Referências \\
\hline Krug & 1 & 8,9 & LONNQUIST (1961) \\
Krug & 1 & 14,9 & SILVA \& LONNQUIST (1968) \\
Jarvis & 1 & 3,5 & MOLL \& STUBER (1971) \\
Indian Chief & 6 & 2,8 & MOLL \& STUBER (1971) \\
(Va17 x Va29) & 4 & 9,3 & GENTER (1976) \\
Krug & 4 & 4,7 & COMPTON \& LONNQUIST (1982) \\
Nebraska Krug & 10 & 4,7 & STROMBERG \& COMPTON (1989) \\
Nc7 x Ci21 & 16 & 1,2 & MOLL (1991) \\
\end{tabular}

"Iowa Stiff Stalk", após oito ciclos de seleção recorrente para produção, observaram que a variância genética aditiva permaneceu inalterada, e que a variância genética dominante decresceu, significando que com a seleção houve um aumento da freqüência de alelos favoráveis, diminuindo assim a variância genética dominante. A manutenção da variabilidade genética aditiva após ciclos de seleção foi observada ainda por vários autores (LONNQUIST et al., 1966; MOLL \& ROBINSON, 1966; HALLAUER, 1970; ALLEN et al., 1978; HALLAUER, 1971). Por outro lado, SILVEIRA et al. (1991), avaliando alterações na variabilidade genética em vários caracteres em duas populações de milho, observaram que após dois ciclos de seleção para produção de grãos, a variabilidade genética para esse caráter decresceu, e que as maiores alterações foram observadas nos caracteres que apresentaram altas correlações com a produção, evidenciando os efeitos da resposta correlacionada sobre a variabilidade genética. STROMBERG \& COMPTON (1989), após dez ciclos de seleção para produção na população Nebraska Krug, obtiveram ganhos até o quarto ciclo de seleção, após o qual a 
produção pareceu ter atingido um platô, indicando uma queda na variabilidade genética da população. Outros autores também registram decréscimo na variabilidade de populações após sucessivos ciclos de seleção (MOLL, 1991 ; LANDI \& FRASCAROLI, 1993). Esses resultados contrastantes são de certa maneira explicáveis, pois conforme comentam SILVA \& LONNQUIST (1968), a alteração da variância genética depende da freqüência gênica, do grau de dominância, da intensidade de seleção e do número de indivíduos selecionados para a síntese da próxima geração, estando assim a alteração da variabilidade genética estreitamente relacionada com a população submetida à seleção $\mathrm{e}$ com a estratégia de seleção adotada.

Pelo exposto até o momento, torna-se clara a importância do conhecimento da variância genética aditiva para o sucesso de um processo de seleção. É através deste componente da variação hereditária que são estimados parâmetros genéticos como o coeficiente de herdabilidade, progresso esperado com seleção, correlação genética entre caracteres e resposta correlacionada à seleção, que vão orientar o melhorista na estratégia a ser adotada em seu programa.

A herdabilidade de um caráter métrico é uma de suas mais importantes propriedades. Ela expressa a proporção da variância total que é atribuida ao efeito médio dos genes, que determina o grau de semelhança entre parentes (FALCONER, 1964). Mede a importância relativa de fatores genéticos na expressão fenotípica entre genótipos de uma população, indicando a confiança do valor fenotípico como expressão do valor genético. Seu valor é fundamental na definição do método de seleção a ser utilizado. VENCOVSKY (1978), relatou que para caracteres cujos coeficientes de herdabilidade no sentido restrito situam-se nos limites de 0 a $10 \%$ e de 10 a $30 \%$, a seleção fenotípica ou massal apresenta muito baixa ou baixa eficiência, respectivamente, o que implica na utilização de métodos mais eficientes, a exemplo daqueles que se apóiam em testes de progênies. Por outro lado, quando os coeficientes de herdabilidade encontram-se entre 30 e $50 \%$ ou mais, a seleção fenotípica apresenta resultados satisfatórios. A função mais importante da herdabilidade está no papel preditivo que ela desempenha, indicando o grau de correspondência entre o fenótipo e o genótipo. Por esta razão participa de quase todas as fórmulas relacionadas com métodos de melhoramento, e muitas decisões práticas sobre procedimentos a serem utilizados, dependem de sua magnitude (FALCONER, 1964). É importante frisar que a herdabilidade é uma propriedade não só do caráter, mas da população, que é influenciada por fatores ambientais. Portanto, o grau de herdabilidade é caracterizado atráves da média de vários dados acumulados de 
diversos genótipos em diversos ambientes. Através do coeficiente de herdabilidade é possível obter-se o progresso esperado com seleção, que segundo VENCOVSKY (1978), além de permitir uma antevisão das alterações causadas pela seleção na média de um dado caráter populacional, possibilita a realização de comparações entre diferentes processos de seleção, servindo como um critério técnico para que o melhorista julge que método de melhoramento deve ser mais eficiente em suas condições de trabalho.

Outro aspecto relevante a ser observado em um programa de melhoramento é a associação entre caracteres. Segundo VENCOVSKY \& BARRIGA (1992), o estudo da natureza e magnitude das relações existentes entre caracteres é evidentemente importante pois no melhoramento em geral, preocupa-se em aprimorar o material genético não para caracteres isolados, mas para um conjunto destes simultaneamente. Torna-se então, fundamental saber como o melhoramento de uma característica pode causar alterações em outras.

As causas da correlação genética são o pleiotropismo e o desequilibrio de ligação gênica (FALCONER, 1964; VENCOVSKY, 1978; HALLAUER \& MIRANDA FILHO, 1988). O pleiotropismo é a propriedade pela qual um gene afeta dois ou mais caracteres simultaneamente, podendo aumentar ou diminuir as duas características no caso de correlação positiva, ou aumentar uma e diminuir a outra, no caso de correlação negativa. Já os efeitos de desequilíbrio de ligação referem-se a genes localizados no mesmo cromossomo com tendência a serem transmitidos em conjunto; todavia, a associação de caracteres, uma vez que podem ser transitórios, tal efeito é dissipado pela recombinação gênica.

Assim como as herdabilidades, é esperado que as correlações genéticas sofram alterações à medida que processos seletivos sejam aplicados na população ou conjunto gênico básico. Se a seleção for aplicada, por exemplo, a duas características positivamente correlacionadas, espera-se que a correlação entre elas torne-se negativa pelo fato de aqueles genes pleiotrópicos, que afetam ambos os caracteres na dirę̧ão desejada, serem fortemente impelidos pela seleção e levados rapidamente em direção à fixação, contribuindo assim muito pouco para a variância ou covariância dos dois caracteres; por outro lado, os genes pleiotrópicos que afetam um caráter favoravelmente e o outro adversamente serão muito menos influenciados pela seleção e permanecerão por mais tempo em freqüências intermediárias. Deste modo, a maior parte da covariância entre os caracteres será atribuida a esses últimos genes, tomando assim a correlação negativa (FALCONER, 1964). 
Uma das aplicações mais importantes das correlações refere-se à seleção indireta de caracteres que apresentam baixa herdabilidade, ou seja, que respondem pouco à seleção. Pratica-se então, seleção em um caráter visando-se a modificação em outro. Para isso precisa-se de duas condições básicas: 1) os caracteres precisam ser altamente correlacionados; 2) o caráter secundário precisa possuir herdabilidade superior ao caráter principal (GERALDI, 1977; HALLAUER \& MIRANDA FILHO, 1988; VENCOVSKY \& BARRIGA, 1992). Para produção por exemplo, dois caracteres secundários já foram identificados em milho quais sejam: prolificidade (PATERNIANI, 1980) e o tamanho do pendão(GERALDI, 1977).

Até o momento foi feita uma abordagem geral sobre parâmetros genéticos em milho, observando-se a importância da estimação dos mesmos no que se refere às aplicações e beneficios que trazem ao melhoramento genético. A seguir é feita uma abordagem sobre os caracteres estudados no presente trabalho, em especial àqueles submetidos à seleção, quais sejam: altura de espigas e número de ramificações do pendão, associando-os aos demais caracteres avaliados (altura de planta, comprimento e peso de pendão e peso de espigas).

\subsection{ALTURA DE ESPIGAS}

O germoplasma de milho das regiões tropicais caracteriza-se por possuir porte de planta e espiga elevados, que segundo FISHER et al. (1987), é uma estratégia evolutiva dos milhos destas regiões devido à forte competição com as pragas, doenças e plantas daninhas. Esta altura excessiva acarreta porém, grandes perdas em produção, tendo em vista que as plantas de porte elevado são, via de regra, mais sujeitas ao acamamento. Em função deste fato, a redução do porte de milho constitui objetivo importante nos programas de melhoramento (PATERNIANI, 1974; MIRANDA FILHO, 1974; SAMPAIO, 1986).

Existem basicamente duas alternativas para redução do porte do milho: 1) através de genes maiores (gene braquítico ou gene do nanismo); 2) através de poligenes (CIMMYT, 1972; MIRANDA FILHO, 1974; PATERNIANI, 1978; SOUZA Jr \& ZINSLY, 1981; SILVA, 1984). Com relação ao gene braquitico, este tem sido utilizado no melhoramento pelo fato de reduzir a altura da planta e da espiga através da redução do comprimento e não do número de internódios, sendo que o número de folhas permanece o mesmo. $\mathrm{O}$ controle poligênico reduz estes parâmetros através da redução 
do número e do comprimento de internódios. De acordo com ARAÚjO (1992), atualmente os programas de melhoramento estão buscando a redução de altura de planta e altura de espiga através de poligenes, pois a utilização do gene maior "braquítico 2", traz consigo caracteres indesejáveis como folhas mais largas e espessas, menor transmissão de luz para folhas próximas da espiga, dossel espesso e altura, às vezes, excessivamente baixa.

Segundo MIRANDA FILHO (1974), estudos e observações sobre altura da planta e altura da espiga em milho têm sido realizadas há muito tempo, principalmente relacionadas com os resultados da seleção ou com a associação com outros caracteres. LEONARD \& KIESSELBACH (1932) obtiveram duas subpopulações divergentes em relação ao tamanho da espiga e observaram uma maior produção para a subpopulação com maior altura de espiga.

Vários outros trabalhos demostram a eficiência com a seleção para altura de espiga, como os de PATERNIANI (1967) e ACOSTA \& CRANE (1972). ANDRADE (1988), após três ciclos de seleção divergente aplicados na população ESALQ PB-1, observou que a altura de espiga foi facilmente alterada pela seleção, obtendo um efeito direto da seleção de $2,91 \%$ /ciclo na seleção positiva e $2,84 \%$ /ciclo na seleção negativa. Verificou ainda que a seleção na altura da espiga alterou expressivamente a altura da planta, aumentando-a na seleção positiva e diminuindo-a na seleção negativa. ARAÚJO (1992), trabalhando com a mesma população já no quinto ciclo de seleção divergente, confirmou a alta correlação positiva entre altura de planta e altura de espiga.

GIESBRECHT (1961), concluiu que a herança da altura de espiga deve ser, provavelmente, governada por seis fatores genéticos, e em relação à altura de planta, YANG (1949) associou três pares de genes no controle do caráter. Conforme SANTOS (1985), a manifestação desses caracteres possivelmente relaciona-se a um número não muito grande de genes, visto que o ambiente exerce pouca influência sobre os mesmos. Muitos trabalhos conduzidos por diversos autores indicam uma alta herdabilidade para o caráter altura de espiga. Assim, REGAZZI et al. (1980), estimaram herdabilidade de $70,02 \%$ no sentido amplo e $25,10 \%$ no sentido restrito para o Composto Dentado B. TOSELLO \& GERALDI (1980), estimaram a herdabilidade no sentido restrito de 57,64\% para a população ESALQ-VD opaco. ARAÚJO (1992) estimou para a população ESALQ PB-1 herdabilidade na ordem de $63,73 \%$. Diversos outros trabalhos confirmam a alta herdabilidade do caráter (MIRANDA FILHO et al., 
1974; LIMA \& PATERNIANI, 1977; MIRANDA FILHO, 1978; GHINI \& MIRANDA FILHO, 1979; LORDELO, 1982; SANTOS, 1985; SAMPAIO, 1986).

Extenso levantamento sobre estimativas de parâmetros genéticos publicados para altura de planta e altura de espiga foi realizado por MORAES (1989). Para as populações de milho brasileiras, dados de 36 estimativas mostraram um valor médio para a variância aditiva de $278(\mathrm{~cm} / \text { planta })^{2}$ para altura de planta e de $188(\mathrm{~cm} / \text { planta })^{2}$ para altura de espiga. Para o caráter altura de planta, a variância aditiva teve um intervalo de variação de 10,0 a 698,0 (cm/planta $)^{2}$, e para altura de espiga esse intervalo foi de 10,0 a $548,0(\mathrm{~cm} / \mathrm{planta})^{2}$. O autor observou ainda valores de herdabilidade ao nível de médias na ordem de 63,4\% e 63,7\% para altura de planta e altura de espiga, respectivamente. Os dados levantados pelo autor encontram-se na Tabela 02 .

Os estudos sobre os componentes da variação genética indicam que esses caracteres são controlados predominantemente por genes com efeitos aditivos (GARDNER et al., 1953; STUBER et al., 1966; RUSSELL \& EBERHART, 1970; HALLAUER, 1971; SUBANDI \& COMPTON, 1974; RUSSELL, 1976; HALLAUER \& MIRANDA FIHO, 1988); com relação ao grau médio de dominância, estimativas indicam a presença de dominância parcial relativa à maior altura de planta e de espiga, reforçando assim a hipótese de predominância de genes aditivos (COMSTOCK \& ROBINSON, 1948; ROBINSON et al., 1949; GARDNER \& LONNQUIST, 1959), demonstrando que esses caracteres podem ser reduzidos através do uso de seleção recorrente.

ARAÚJO (1992), trabalhando com a população ESALQ PB-1, no quinto ciclo de seleção divergente para maior $(E+)$ e menor $(E-)$ altura de espiga, estimou a variância genética aditiva para altura de espigas na ordem de 167,35 e 68,85 $(\mathrm{cm} / \text { planta })^{2}$, respectivamente. Para altura de planta o autor observou estimativas da variância aditiva de 254,20 e 131,11 (cm/planta) ${ }^{2}$, para E+e E-, respectivamente. NASS (1992), avaliando duas populações semi-exóticas de milho encontrou valores médios da variância genética aditiva na ordem de 285,89 e 245,29 (cm/planta) ${ }^{2}$ para os caracteres altura de planta e altura de espiga, respectivamente.

A associação da altura de espiga com outros caracteres é objeto de estudo em diversos trabalhos. Segundo MIRANDA FILHO (1974), são de especial interesse aqueles que relacionam a altura de espiga ao acamamento. $O$ acamamento de plantas no campo, como mencionado anteriormente, acarreta danos à produção pelo menor número de espigas colhidas, sendo a resistência ao acamamento um dos principais objetivos dos 
Tabela 02- Resumo das estimativas de parâmetros genéticos para altura de planta e altura de espiga obtidas por vários autores em populações de milho nacionais e estrangeiras. Dados compilados por MORAES (1989).

\begin{tabular}{|c|c|c|c|c|c|c|}
\hline \multicolumn{4}{|c|}{$\begin{array}{l}\text { POPULAQOUES DE MIIUO } \\
\text { BRASIIEIRAS }\end{array}$} & \multicolumn{3}{|c|}{$\begin{array}{l}\text { POPULAQOES DE MUHO } \\
\text { ESTRANGEIRAS }\end{array}$} \\
\hline & $\begin{array}{l}\text { RODE } \\
\text { ATIVAS }\end{array}$ & $\begin{array}{c}\text { NIERVALO } \\
\text { DE } \\
\text { VARIACÃO }\end{array}$ & MÁDA & $\begin{array}{l}\text { NÚMERODE } \\
\text { ESIIMAATVAS }\end{array}$ & $\begin{array}{c}\text { INIERVALO } \\
\text { DE: } \\
\text { VARIAÇÃO }\end{array}$ & MÉDIA \\
\hline \multicolumn{7}{|c|}{ ALT.DEPLANTA } \\
\hline$\sigma_{A}^{2}(\mathrm{an})^{2}$ & 36 & 10,0 a 698,0 & 278,0 & 58 & $110,0 \mathrm{a} 642,0$ & 22230 \\
\hline$\sigma_{D}^{2}(a n)^{2}$ & 1 & - & so,o & $\$ 2$ & 20,0 a 412,0 & 52,37 \\
\hline $\mathrm{H}^{2}$ & 32 & 13,38 a 167,37 & 63,14 & 49 & 11,50 a 64,60 & 55,93 \\
\hline $\mathrm{CVg}_{\mathrm{g}}$ & 22 & 2,03 a 8,07 & 4,44 & - & - & - \\
\hline $\mathrm{CVe}$ & 32 & 3,38 a 9,21 & 6,04 & - & - & - \\
\hline $\mathrm{CVg}_{\mathrm{g}} / \mathrm{CVe}$ & 16 & 0,31 a 0,88 & 0,66 & - & - & - \\
\hline Gs/CICLO(\%) & 27 & 0,34 a 17,92 & 5,06 & 4 & 3,89 a 5,55 & 4,48 \\
\hline \multicolumn{7}{|c|}{ ALT.DE ESPIGA } \\
\hline$\sigma_{A}^{2}(a m)^{2}$ & 36 & 10,0 a 548,0 & 188,0 & 70 & $11,0 \mathrm{~A} 484,0$ & 150,71 \\
\hline$\sigma_{D}^{2}(\mathrm{am})^{2}$ & 1 & - & 36,0 & 58 & 8,0 a 85,0 & 13,34 \\
\hline $\mathrm{H}^{2}$ & 34 & 17,0 a 112,75 & 63,78 & 58 & $47,0 \mathrm{a} 93,0$ & 67,09 \\
\hline $\mathrm{CVg}_{\mathrm{g}}$ & 22 & 3,41 a 10,34 & 6,68 & 4 & 7,0 a 10,10 & 895 \\
\hline $\mathrm{CVe}$ & 31 & 2,48 a 13,77 & 8,55 & 4 & 4,10 & 4,10 \\
\hline $\mathrm{CVg} / \mathrm{CVe}$ & 16 & $0,36 \mathrm{a} 0,99$ & 0,70 & - & - & - \\
\hline Gs/CICLO(\%) & 25 & 0,01 a 28,40 & 9,16 & 4 & 8,56 a 13,75 & 10,76 \\
\hline
\end{tabular}


programas de melhoramento de milho. JOSEPHSON \& KINCER (1977), relatam que a tendência a uma maior resistência ao acamamento dos genótipos de espiga baixa decorre do fato de que com a espiga mais baixa, diminui-se o efeito de alavanca que a espiga exerce sobre o colmo, contribuindo assim para um menor acamamento. Porém, a literatura reporta resultados contraditórios; REMINSON \& AKINLEYE (1978), encontraram correlações de 0,46 e 0,71 entre porcentagem e acamamento e altura de espiga. Entretanto, ACOSTA \& CRANE (1972), observaram que a seleção para menor altura de espiga aumentou a resistência ao acamamento em uma população, mas diminuiu em outra, levando os autores a concluirem que esta associação seria uma propriedade intrapopulacional.

Como ressaltado por ARAÚJO (1992), a resistência ao acamamento é um caráter por demais complexo, tendo muitos fatores influenciando-a. Além do efeito alavanca, outros fatores causadores do acamamento são, segundo LAVENDOVSKI (1987), o complexo de doenças que atingem o colmo e o desbalanceamento nutricional entre esse orgão e a espiga. Os trabalhos visando uma melhor qualidade do colmo, segundo MAGALHÃES \& SILVA (1987), vão resultar em um aumento dos sítios de consumo representados pelos orgãos vegetativos, aumentando assim a resistência física do colmo, podendo, porém, redirecionar os produtos fotoassimilados da espiga para $o$ colmo, reduzindo a produção de grãos. Esses fatos, segundo os autores, indicam a necessidade de se produzir um germoplasma mais balanceado, equilibrando o aumento dos sítios de produção com os sítios de consumo.

Vários também são os trabalhos visando determinar a associação entre altura de espiga e altura de planta com a produção de grãos. BURGESS \& WEST (1993), avaliando um sintético após dez ciclos de seleção recorrente para redução da altura de espiga, observaram que esse caráter foi reduzido em $29 \%$, mantendo a altura de planta perto do original, porém com um decréscimo na produção na ordem de $30 \%$. Os mesmos autores submeteram esse sintético a mais quatro ciclos de seleção, desta vez para produção, conseguindo um aumento na produção de cerca de $30 \%$, ou seja, ao nível da população original, com um aumento de $8 \%$ na altura de espiga. REDDY et al. (1990), submeteram três populações a quatro ciclos de seleção recorrente, sendo que em uma delas a seleção teve como base a produção de grãos e nas demais a prolificidade. Os autores observaram aumentos em todas as populações tanto para produção quanto para altura de planta e altura de espiga. Observaram, no entanto, que nas populações selecionadas com base na prolificidade, embora os ganhos em produção terem sido 
menores, apresentaram menores acréscimos nas alturas de planta e de espiga, sugerindo que a seleção para prolificidade pode ser uma boa opção por não trazer consigo essas alterações indesejáveis. Resultados semelhantes evidenciando correlações positivas entre estes caracteres já foram relatados por diversos autores (LINDSEY et al., 1962; ACOSTA \& CRANE, 1972; LIMA \& PATERNIANI, 1977; RISSI, 1980; REGAZZI et al., 1982; REIS et al., 1982; ARAÚJO, 1992; LANDI \& FRASCORALI, 1993).

Por outro lado, vários autores já obtiveram correlações negativas (DARRAH et al., 1972; SAMPAIO, 1986), e ausência de correlação (QUEIROZ, 1969; OBILANA \& HALLAUER, 1974; OCHUNG \& KAMIDI, 1992) entre os caracteres altura de espiga e produção. Estes resultados concordam com MIRANDA FILHO (1974), que indica que a correlação entre estes caracteres é de propriedade intrapopulacional, embora essas correlações sejam usualmente positivas (HALLAUER \& MIRANDA FILHO, 1988).

ANDRADE \& MIRANDA FILHO (1980), estimaram para a população ESALQ PB-1 correlações genotípicas de 0,68 entre altura de planta e altura de espiga, de 0,36 entre altura de planta e número de ramificações do pendão, e de 0,44 entre altura de espiga e número de ramificações do pendão. ANDRADE (1988), comparou três ciclos de seleção divergente para altura e espiga e número de ramificações do pendão, mais os cruzamentos entre linhas divergentes de cada ciclo e a população original ESALQ PB-1, relatando alta eficiência na seleção para altura de espiga em ambas as linhas, E+ e E-. $\mathrm{O}$ autor obteve um ganho simétrico nas linhas E-(-8,51\%), e $\mathrm{E}+(8,73 \%)$. A seleção para maior altura de espiga aumentou também altura de planta e número de ramificações do pendão, enquanto que a seleção para menor altura de espiga reduziu esses mesmos caracteres. ARAÚJO (1992), avaliando o quinto ciclo de seleção divergente, concluiu que a correlação entre os caracteres altura de planta e altura de espiga permaneceu elevada, não sofrendo modificações ao longo dos ciclos de seleção.

\subsection{TAMANHO DO PENDÃO}

As observações acerca das relações da inflorescência masculina do milho, o pendão, com a produção de grãos, datam do início do século. Esses estudos realizados não tinham, no entanto, muita importância prática. Foi com o advento do milho híbrido que esses estudos se revestiram de grande importância, pois o despendoamento tornouse prática obrigatória nos campos de produção de sementes híbridas. Neste sentido, 
aumentou-se o interesse de verificar se o despendoamento causava algum tipo de dano à planta. LEONARD \& KIESSELBACH (1932), observaram aumentos na produção de grãos na ordem de $1,5 \%$ com a prática do despendoamento, fato esse também constatado por DUNGAN \& WOODWORT (1939). Os últimos autores constataram ainda um decréscimo na produção de grãos de $8,3 \%, 15,3 \%, 8,1 \%$ e $29,2 \%$, quando eram removidas juntamente com o pendão uma, duas, três e quatro folhas, respectivamente. Esses trabalhos levaram os autores a concluírem que a prática do despendoamento não era prejudicial à planta, desde que não fossem removidas as folhas superiores.

Posteriormente, GROGAN (1956), constatou que acréscimos na produção de grãos em plantas despendoadas ocorriam quando as plantas eram cultivadas em condições desfavoráveis, como : 1) em condições de seca; 2) em condições de baixa fertilidade; 3 ) em condições de alta densidade populacional. Outros autores obtiveram resultados semelhantes (DUNCAN et al., 1967; HUNTER et al. , 1969; BUREN et al., 1974; MOCK \& SCHUETZ, 1974; PATERNIANI \& GERALDI, 1980; SOUZA Jr et al., 1985).

O pendão começa a funcionar precocemente, exigindo portanto nutrientes antes que a espiga. Quando o pendão é removido a espiga floresce dois ou três dias mais depressa (GROGAN , 1956 ; CHINWUBA et al. , 1961). Esse fato levou os pesquisadores a concluirem que o efeito negativo do pendão sobre a produção de grãos seria devido à competição por nutrientes. Neste sentido, o pendão goza de uma grande vantagem por se formar antes da espiga, constatando-se que até a manifestação da antese, o pendão representa o principal ponto de crescimento da planta (ANDERSON, 1971). Em ambientes desfavoráveis, onde a disponibilidade de nutrientes é limitada, a influência negativa do pendão sobre o desenvolvimento da espiga é mais pronunciada, haja vista que as associações negativas entre o pendão e a produção têm-se evidenciado, como citado anteriormente, sob condições adversas.

Muitos também foram os trabalhos visando quantificar a influência do citoplasma macho-estéril na produção de grãos, através da comparação entre genótipos semelhantes diferindo quanto ao tipo de citoplasma . Neste sentido, RODGERS \& EDWARDSON (1965), constataram uma superioridade na produção de grãos das plantas macho-estéreis em relação às plantas com citoplasma normal, fato este confirmado em outros trabalhos (CHINWUBA et al. , 1961; DUVICK, 1958; JOSEPHSON \& KINCER, 1962; BRUCE et al., 1966). SANFORD et al. (1965), 
verificaram que durante a antese as plantas normais continham $30 \%$ a mais de nitrogênio que as plantas macho-estéreis, que por sua vez, apresentavam maiores quantidades de nitrogênio que as plantas normais nas palhas e espigas, resultando em uma produção de grãos $30 \%$ superior. $O$ autor constatou ainda, que a quantidade de nitrogênio total no período de maturação fơi maior nas plantas macho-estéreis devido, provavelmente, à quantidade perdida pelas plantas normais no despreendimento de pólen. Resultados concordantes foram apresentados por CRISWELL et al. (1974), que trabalhando com carbono (14C), constataram uma menor translocação de carboidratos para os pendões das plantas macho-estéreis em relação às plantas normais, e conseqüentemente,uma maior translocação para as espigas nos estágios iniciais de desenvolvimento.

O sombreamento causado pelo pendão nas folhas superiores da planta, tem sido relacionado também como causa dessa associação negativa entre pendão e produção de grãos. DUNCAN et al. (1967), trabalhando com simulação de computador, observaram que a área projetada por um pendão no transcorrer de um dia variou, em média, de 90 a $141 \mathrm{~cm}$, o que pode ocasionar reduções na ordem de $4 \%$ e $12 \%$ em densidades de 25.000 e 75.000 plantas por hectare, respectivamente. $\mathrm{O}$ autor entretanto, não descartou a hipótese da competição por nutrientes.

Segundo FISHER et al. (1987), os milhos tropicais são mais sensíveis à redução da fotossintese na época do florescimento, e conforme ressaltado por EASTIN (1970) e EDMEADES et al. (1979), as folhas mais próximas à espiga são as que mais contribuem para o seu crescimento, ficando a produção de grãos diretamente associada à maior iluminação das folhas adjacentes às espigas em crescimento. LAMBERT \& JOHNSON (1978), combinando despendoamento, não despendoamento e remoção das ramificações laterais com três tipos de inserção de folhas, constataram que o efeito do sombreamento é maior nos tipos de folha normal e menor nos tipos de folha ereta POZAR (1981), trabalhando com materiais de base genética semelhante, diferindo em relação ao tipo de folha, chegou a resultados similares, ou seja, a iluminação é maior em folhas de posição mais vertical. Portanto, conforme ressaltado por ARAÚJO (1992), o efeito do sombreamento é complexo e não deve ser atribuido exclusivamente ao pendão.

MOCK \& PEARCE (1975), diante dos resultados relacionados à influência do pendão do milho na sua produção, sugeriram uma seleção para pendões menores pois, segundo os autores, essa seria uma das características do ideótipo para a cultura do milho. Visando então dar início a um trabalho de melhoramento genético e sabendo, que o primeiro passo para isso é o estudo das bases genéticas do caráter e a variabilidade do 
mesmo na população, MOCK \& SCHUETZ (1974), estudaram a herança do número de ramificações do pendão, constatando que o caráter tem herança quantitativa com um mínimo de oito fatores genéticos envolvidos, e que a expressão do caráter depende principalmente de efeitos gênicos aditivos. Os autores estimaram ainda um coeficiente de herdabilidade no sentido restrito de aproximadamente $50 \%$, indicando que o sucesso com seleção pode ser obtido através de métodos relativamente simples.

No Brasil, os primeiros estudos foram realizados por GERALDI (1977), que estudando três populações de milho, estimou alguns parâmetros genéticos para os caracteres número de ramificações, peso e comprimento do pendão. $\mathrm{O}$ autor concluiu ser o número de ramificações o melhor caráter para dimensionar o pendão, pois além de fácil visualização no campo, é o caráter primário negativamente correlacionado com a produção $\left(r_{A}=-0,650\right)$, enquanto que o peso de pendão só apresenta correlação genética negativa com a produção de grãos devido à influência do número de ramificações, isto é, pelo fato de ser positivamente correlacionado ao número de ramificações ( $r_{\mathrm{A}}=+0,477$, em média para as duas populações). $\mathrm{O}$ autor estimou em 10,76 (média das três populações estudadas), a variância genética aditiva para número de ramificações do pendão.

A Tabela 03 apresenta um resumo de estimativas de parâmetros genéticos obtidas por diversos autores. As estimativas para as variâncias genéticas aditivas $\left(\sigma_{A}^{2}\right)$, variaram de 6,50 a $53,10 \mathrm{~cm}$ alcançando uma média de $23,93 \mathrm{~cm}$ enquanto que as estimativas para o $\mathrm{h}^{2}$ variaram de 52,30 a $89,50 \%$, com uma média de $69,50 \%$.

Embora os trabalhos relatando associações negativas entre o tamanho do pendão e a produção de grãos sejam numerosos, (LEONARD \& KIESSELBACH, 1932; HUNTER et al., 1973; GERALDI, 1977; FACOREDE \& MOCK, 1978; LORDELO \& MIRANDA FILHO, 1981; LORDELO, 1982; SEGOVIA, 1983; GERALDI et al., 1985; ANDRADE et al., 1986; MARTINS, 1986; SAMPAIO, 1986),associações positivas foram observadas por vários autores (LORDELO \& MIRANDA FILHO, 1981; LORDELO, 1982; AGUILAR MORÁN, 1984; SAMPAIO, 1986; SOARES FILHO, 1987). Segundo SOARES FILHO (1987), em ambientes favoráveis à cultura do milho, tais associações podem ser positivas sendo, a contrário, tanto mais negativas quanto menos adequadas forem as condições de cultivo. Deve-se considerar também que, conforme BRUNINI et al. (1983), variáveis ambientais como fotoperíodo, radiação solar e precipitação pluviométrica influem decisivamente sobre a produção e portanto, sobre 
seus componentes, existindo resposta varietal diferenciada para cada um desses fatores, tornando muitas vezes inconsistentes os resultados das associações entre caracteres.

Tabela 03- Estimativas de parâmetros genéticos para o caráter número de ramificações do pendão em milho obtidas por diversos autores.

\begin{tabular}{|c|c|c|c|c|c|c|c|}
\hline POIUL $\Lambda C ̧ X ̃ O O$ & MÉDI & $\sigma_{A}^{2}$ & $h^{2} r \%$ & $h^{2} m \%$ & $\mathrm{CVg}_{\mathrm{g}} \%$ & CVe\% & REDERANCLS \\
\hline BSSS-11 X BSSS 261 & - & 53,10 & 53,40 & 89,00 & - & - & MOCK\& SCHUETZ (1974) \\
\hline COMPOSIO DENT. BOO & 18,10 & 6,50 & 30,7 & - & - & - & GERALDIeal (1985) \\
\hline COMPOSIOFUNT & 22,40 & 10,56 & 43,40 & - & - & - & GERALIetal (1985) \\
\hline CENTRALMEX & 18,70 & 15,23 & 63,10 & - & - & - & GERALI et al (1985) \\
\hline ESALQPB-1 & 18,40 & 14,12 & 61,62 & 74,07 & - & 12,05 & ANDRADE\& MIRANDAFLHO(1979) \\
\hline PIRANÃO VD2 & 23,80 & 23,44 & 57,22 & - & 10,16 & 9,44 & LORDELO(1982) \\
\hline PIRANÃO VFI & 31,00 & 43,96 & 57,42 & - & 10,58 & 13,00 & LORDELO(1982) \\
\hline SINIÉITCOFUNI & 25,50 & 23,73 & 48,44 & $\$ 230$ & 9,54 & 11,80 & AGUILAR MORAN(1984) \\
\hline SINIÉTTCODENT & 21,90 & 27,68 & 67,48 & 63,02 & 1201 & 14,00 & AGUII_AR MORAN(1984) \\
\hline ESALQPB-1 & 24,04 & 28,00 & 56,98 & 65,69 & - & 13,80 & SANTOS (1985) \\
\hline CRAVOXESALQPB-1 & 23,13 & 22,38 & 48,17 & 63,30 & - & 13,47 & SANIOS(1985) \\
\hline ENTREL XESALQ.PB-1 & 2828 & 2828 & 36,60 & 62,56 & - & 11,89 & SANTOS (1985) \\
\hline ESALQPB-4 & 23,91 & 23,60 & 61,77 & 71,75 & 10,16 & 11,04 & SAMPAIO(1986) \\
\hline ESALQPB-S & 24,25 & 28,17 & 64,25 & 74,51 & 10,94 & 11,08 & SAMPAIO(1986) \\
\hline ESALQPB-1 & 26,83 & 22,00 & - & 6829 & - & 12,60 & ARAU்O(1992) \\
\hline
\end{tabular}

SOUZA Jr. et al. (1985), observaram em seus estudos correlação positiva entre NR e prolificidade, e para explicar tal fenômeno baseou-se em estudos de natureza fisiológica feitos por ANDERSON (1967). Este autor observou que híbridos prolíficos possuíam menor quantidade de ácido Indolacético (IAA) que os não prolíficos, concluindo assim que a prolificidade era devido à redução da dominância apical exercida pelo pendão. Portanto, com um pendão menor a produção de IAA diminuiria alterando o balanço ácido giberélico-IAA em favor do primeiro, fazendo assim com que mais de uma gema axilar tivesse oportunidade de se desenvolver e diferenciar-se em espiga. 
Os estudos sobre correlações entre tamanho do pendão e outros caracteres são também contraditórios. A tabela 04 apresenta um resumo de estimativas de correlações realizadas no Brasil. As associações entre número de ramificações e altura de espiga, e entre altura de plantas e posição relativa da espiga, foram relatadas como positivas (OBILANA \& HALLAUER, 1974; ANDRADE \& MIRANDA FILHO, 1980; AYALA OSUNA et al., 1986), e correlações ora positivas, ora negativas (LORDELO, 1982; AGUILAR MORAN, 1984; SAMPAIO, 1986; SOARES FILHO, 1987, ARAÚJO, 1992). O último autor, avaliando a população ESALQ PB-1 no quinto ciclo de seleção divergente para altura de espiga e número de ramificações do pendão, encontrou correlações entre esses caracteres variando entre 0,028 e 0,278 . Segundo o autor, as alterações ocorridas nas correlações em relação à população original foram decorrentes não só da seleção, como também das condições ambientais.

Tabela 04- Resumo de estimativas de correlações genéticas aditivas ( $\mathrm{r}_{\mathrm{A}}$ ) e correlações fenotípicas ( $\mathrm{r}_{\mathrm{F}}$ ) ao nível de média de famílias, envolvendo o caráter número de ramificações do pendão com os caracteres altura de plantas (AP), altura de espigas (AE) e peso de grãos (PG) obtidas por diversos autores.

\begin{tabular}{|c|c|c|c|}
\hline & $\begin{array}{l}\text { NÚMERO DE } \\
\text { ESTIMATIVAS }\end{array}$ & $\begin{array}{c}\text { INTERVALO DE } \\
\text { VARIAÇÃO }\end{array}$ & MÉDIA \\
\hline $\mathrm{r}_{\mathrm{A}}$ & 13 & $-0,184$ a 0,363 & 0,054 \\
\hline $\mathrm{r}_{\mathrm{F}}$ & 17 & $-0,111$ a 0,289 & 0,138 \\
\hline$r_{A}$ & 13 & $-0,269$ a 0,436 & 0,108 \\
\hline $\mathbf{r}_{\mathbf{F}}$ & 17 & -0.037 a 0,308 & 0,204 \\
\hline $\mathrm{r}_{\mathrm{A}}$ & 13 & $-0,642$ a 0,112 & $-0,197$ \\
\hline $\mathrm{r}_{\mathrm{F}}$ & 20 & $-0,339$ a 0,290 & $-0,046$ \\
\hline
\end{tabular}


PATERNIANI (1981), argumentou sobre a alta correlação entre número de ramificações e posição relativa da espiga com a hipótese da dominância apical exercida pelo pendão. OBILANA \& HALLAUER (1974), concluíram em seus trabalhos que a associação entre o número de ramificações é mais forte com altura de espiga do que com altura de planta. Portanto, a seleção para menor número de ramificações deve ser, conforme ARAÚJO (1992), mais eficiente em diminuir altura da espiga que a altura de planta, diminuindo conseqüentemente, a posição relativa da espiga.

Em função da alta herdabilidade apresentada pelo caráter, grandes progressos podem ser obtidos na seleção para o número de ramificações do pendão. PATERNIANI \& GERALDI (1980), praticando seleção massal para menor número de ramificações em duas populações, obtiveram um ganho de seleção de $21 \%$ na população Piranão VD-2 após três ciclos de seleção e de 7\% com um ciclo de seleção na população Piranão VF-1. ANDRADE (1988), após três ciclos de seleção divergente para altura de espigas e número de ramificações do pendão aplicados na população ESALQ PB-1, observou que o número de ramificações foi facilmente alterado pela seleção, obtendo um efeito direto da seleção de $14,16 \%$ /ciclo na seleção positiva e $8,27 \%$ /ciclo na seleção negativa. Verificou ainda que a seleção no número de ramificações alterou expressivamente diversas características, quais sejam: diminuições em altura de planta, altura de espiga e posição relativa da espiga; aumentos em prolificidade e peso de espiga na seleção negativa e efeitos contrários na seleção positiva.

\subsection{ENDOGAMIA}

Endogamia significa o acasalamento de indivíduos que são relacionados por ascendência. Ela causa um incremento na freqüência de homozigotos e um decréscimo nos genótipos heterozigotos, sendo que a sua mais notável conseqüência é a redução do valor médio fenotípico, mostrado pelos caracteres relacionados com a capacidade reprodutiva ou eficiência fisiológica (FALCONER, 1964). Esta redução no valor adaptativo é conhecida como depressão por endogamia.

A grande importância da endogamia está no desenvolvimento de genótipos que podem ser perpetuados através de múltiplas gerações de produção de sementes com mínimas modificações na sua composição genética, sendo empregada no melhoramento genético tanto para a produção de híbridos de linhagens endogâmicas, quanto para o 
melhoramento de populações. PATERNIANI \& MIRANDA FILHO (1987), citam que o uso de progênies endogâmicas no melhoramento de populações de milho é recomendável para caracteres de baixa herdabilidade, devido ao fato da endogamia conduzir ao aumento da variância genética entre progênies e a um aumento do progresso esperado por ciclo de seleção. Entretanto COCKERHAM (1983), mostrou que sob endogamia, o ganho esperado por seleção pode sofrer influência negativa do componente D1, definido como a covariância entre efeitos aditivos e dominantes dos homozigotos; de fato, sendo Dl uma covariância, pode apresentar valor negativo e refletir negativamente no progresso (LANKLEY \& HALLAUER, 1992). Outro aspecto favorável à seleção com famílias endogâmicas é a possibilidade de seleção contra genes letais ou deletérios (HALLAUER, 1980). Este aspecto é particularmente importante no Brasil, onde as populações atualmente disponíveis apresentam, segundo MARQUES (1988), uma excessiva carga genética, que sob autofecundação expressam uma grande depressão por endogamia.

Conforme relatam HALLAUER \& MIRANDA FILHO (1988), embora um grande número de autofecundações já tenham sido realizadas na cultura do milho, as estimativas de depressão por endogamia para diferentes caracteres é surpreendentemente pequena na maioria dos casos. Em levantamento realizado pelos autores, a depressão endogâmica esperada ao nível de $50 \%$ de homozigoze induzida por autofecundação, foi de 57,58 gramas por planta para produção de grãos, enquanto que para altura de planta e altura de espiga os valores foram de 21,99 e 15,62 cm, respectivamente.

Extenso levantamento foi realizado no Brasil por LIMA et al. (1984), que após estudarem 32 populações brasileiras, observaram que a depressão por endogamia após uma geração de autofecundação variou de $27,0 \%$ a $59,9 \%$ para produção de grãos, de $6,6 \%$ a $20,3 \%$ para altura de planta e de $6,9 \%$ a $27,4 \%$ para altura de espigas. Observaram ainda que as populações derivadas de linhagens endogâmicas apresentaram uma depressão de $34 \%$ inferior à apresentada por compostos e variedades de polinização livre, que ficou em torno de 41,3\%, confirmando o relato de HALLAUER (1980) sobre a seleção contra genes letais e deletérios.

Quanto aos caracteres do pendão, não são muito extensas as informações sobre depressão por endogamia. KASSOUF \& MIRANDA FILHO (1984), estudando a população ESALQ PB-1, constataram valores para a depressão por endogamia de 15,3\% para o caráter NR, enquanto NASS (1992), avaliando duas populações semi-exóticas de milho, observou após uma geração de autofecundação valores para a depressão 
endogâmica para NR de $19,4 \%$ e $12,7 \%$. A quantificação do valor da depressão para esses caracteres é importante no tocante ao suprimento de pólen em um programa de produção de híbridos de linhagens endogâmicas, especialmente quando a população base para a extração das linhagens tenha naturalmente pouco número de ramificações ou tenha sido melhorada para essa característica. 


\section{MATERIAL E MÉTODOS}

\subsection{MATERIAL}

O material genético utilizado no presente trabalho consistiu de seis subpopulações obtidas através de seis ciclos de seleção divergente para altura de espiga (AE) e número de ramificações do pendão (NR), aplicados à população ESALQ PB-1. Em quatro dessas subpopulą̧ões, utilizou-se progênies de irmãos germanos (IG) e nas duas outras utilizou-se progênies oriundas de autofecundação $\left(S_{1}\right)$.

A população ESALQ PB-1 foi sintetizada a partir de sete variedades de porte baixo no Instituto de Genética da ESALQ/USP, com o objetivo de formação de uma população base para a obtenção de cultivares de porte reduzido (MIRANDA FILHO, 1974). O processo de seleção divergente para AE e NR teve seu início no ano agrícola de 1979/80 em Piracicaba-SP, tendo como base as médias de 147 famílias de meios irmãos da referida população e avaliadas em três látices $7 x 7$, com quatro repetições. Os dados deste primeiro ciclo foram utilizados na estimação dos parâmetros genéticos para os caracteres da planta e pendão por GHINI \& MURANDA FILHO (1979) e ANDRADE \& MIRANDA FILHO (1979), que concluíram que a seleção massal poderia ser tão eficiente na alteração da média do caráter quanto a seleção entre familias de meios irmãos. Nos cinco ciclos seguintes foi utilizada em cada uma das quatro subpopulações a seleção massal para ambos os sexos, através de cruzamentos biparentais entre as plantas selecionadas. No sexto ciclo, além dos cruzamentos biparentais, foram realizadas autofecundações nas subpopulações divergentes para NR, resultando portanto em um total de seis subpopulações. Os resultados do terceiro e quinto ciclos foram apresentados por ANDRADE (1988) e ARAÚJO (1992), respectivamente.

A testemunha utilizada em todos os ensaios foi o cultivar G 85. Trata-se de um híbrido triplo de ciclo precoce (aproximadamente 125 dias), recomendado para os estados de São Paulo e Goiás. 
Foram obtidas no sexto ciclo, cerca de 180 progênies em cada uma das seis subpopulações, as quais são descritas a seguir:

ESALQ PB-1 (E+): subpopulação obtida por seleção visando aumento na altura de espigas ( progênies de IG ).

ESALQ PB-1 (E-): subpopulação obtida por seleção visando diminuição na altura de espigas ( progênies de IG ).

ESALQ PB-1 $(\mathrm{R}+)$ : subpopulação obtida por seleção visando aumento no número de ranificações do pendão (progênies de IG ).

ESALQ PB-1 (R-): subpopulação obtida por seleção visando uma diminuição no número de ramificações do pendão (progênies de IG ).

ESALQ PB-1 $(\mathrm{R}+\mathrm{s})$ : subpopulação obtida por seleção visando um aumento no número de ramificações do pendão (progênies $S_{1}$ ).

ESALQ PB-1 (R-s): subpopulação obtida por seleção visando uma diminuição no número de ramificações do pendão (progênies $S_{1}$ ).

Devido ao grande número de progênies avaliadas em cada subpopulação, as mesmas foram, à exceção da ESALQ PB-1 $(\mathrm{R}+\mathrm{S})$, divididas em três ou quatro ensaios, conforme especificado a seguir :

Subpopulação Número de progênies

$\begin{array}{cccccc} & \text { Ensaio A } & \text { Ensaio B } & \text { Ensaio C } & \text { Ensaio D } & \text { Total } \\ \text { ESALQ PB-1 (R+) } & 50 & 51 & 51 & 28 & 180 \\ \text { ESALQ PB-1 (R-) } & 57 & 56 & 55 & -- & 168 \\ \text { ESALQ PB-1 (E+) } & 55 & 54 & 56 & -- & 165 \\ \text { ESALQ PB-1 (E-) } & 55 & 56 & 54 & 53 & 218 \\ \text { ESALQ PB-1 (R+s) } & 54 & -- & -- & - & 54 \\ \text { ESALQ PB-1 (R-s) } & 49 & 49 & 38 & - & 136\end{array}$

\subsection{MÉTODOS}

\subsubsection{Ensaios de Avaliação}


Os ensaios foram conduzidos em Piracicaba-SP e Rio Verde-GO, obedecendo ao delineamento experimental de blocos casualizados com três repetições. A parcela experimental constituiu-se de uma única linha de 4,0 metros de comprimento, com espaçamento de $0,90 \mathrm{~cm}$ entre linhas, onde foram semeadas 5 plantas por metro linear, alcançando assim uma densidade de aproximadamente 50.000 plantas $/ \mathrm{ha}$.

A semeadura foi realizada manualmente no mês de novembro de 1992 , dentro portanto, do período recomendado para a cultura do milho. Os tratos culturais realizados foram os normais para a cultura, como o controle de invasoras e adubação de cobertura. $\mathrm{O}$ controle de invasoras foi realizado inicialmente através da aplicação de herbicida pré-plantio e posteriormente utilizando-se cultivador à tração animal. A adubação de cobertura foi efetuada cerca de 35 dias após a emergência das plântulas com uma dose de $40 \mathrm{KG} /$ ha de nitrogênio.

Os caracteres avaliados foram :

Altura de Espigas (AE) - medida em centímetros, desde o solo até a inserção da primeira espiga (superior).

Altura de Plantas (AP) - medida em centímetros, desde o solo até a inserção da folha bandeira.

Número de Ramificações do Pendão (NR) - medido em unidades de ramificações primárias.

Comprimento do Pendão (CP) - medido em centímetros .

Peso de Pendão (PP) - medido em gramas.

Peso de Espigas (PE) - medido em gramas, considerando-se a umidade como uniforme em todas as progênies avaliadas.

Os dados de todos os caracteres descritos acima foram tomados em três plantas por parcela, à exceção de PE, onde todas as espigas foram colhidas para posterior pesagem.

Nos ensaios conduzidos em Rio Verde, não foram tomados os dados relativos aos caracteres PP e CP e PE, por indisponibilidade de mão de obra. Também nesta localidade, em decorrência da presença de invasoras, não foram obtidos os dados relativos às subpopulações $R^{+}{ }_{s}$ e $R_{-s}$, assim como só foram obtidos dados de duas repetições nas subpopulações $\mathrm{E}+\mathrm{e} E$-. 
Os dados relativos ao peso de espigas, foram corrigidos ao nível de total de parcelas para o estande ideal (20 plantas), pelo método de correção por covariância, inicialmente proposto por STEEL \& TORRIE (1960), obedecendo ao seguinte modelo :

$\mathrm{PC}=\mathrm{P}-\mathrm{b}(\mathrm{X}-20)$, onde :

PC : Peso de espigas corrigido para o estande ideal.

$P$ : Peso de espigas observado.

b : Coeficiente de regressão linear do peso de grãos em relação às variações do estande.

$\mathrm{X}$ : Estande observado.

As diferenças relativas (DR) entre as subpopulações divergentes para NR $(R+e$ - $)$ e para $A E(E+e$ E-) foram calculadas conforme descrito a seguir :

$\operatorname{DR}(\%)=\frac{\operatorname{MP}(+)-\operatorname{MP}(-)}{\operatorname{MP}(-)} \quad$ x 100, onde :

DR $(\%)=$ Diferença relativa entre as médias populacionais das subpopulações divergentes

MP $(+)=$ Média populacional da subpopulacão divergente para aumento do caráter.

MP ( - ) = Média populacional da subpopulacão divergente para diminuição do caráter.

A depressão por Endogamia ( $1 \%$ ) foi calculada como se segue :

$$
I \%=\frac{m_{S 1}-m_{\mathbb{S}}}{m_{\mathbb{S}}} \times 100 \text {, onde: }
$$

$\mathrm{m}_{\mathrm{S} 1}=$ Média populacional das progênies $\mathrm{S}_{1}$

$\mathrm{m}_{\mathrm{S} 0}=$ Média populacional das progênies $\mathrm{S}_{0}$

3.2.2. Análise Estatística dos Dados.

3.2.2.1. Análises de Variância 
As análises de variância foram realizadas obedecendo ao delineamento experimental de blocos casualisados. Inicialmente realizou-se análise individual dos dados por ensaio dentro de cada local de acordo com o seguinte modelo matemático :

$$
\mathrm{Y}_{\mathrm{ij}}=\mathrm{m}+\mathrm{p}_{\mathrm{i}}+\mathrm{b}_{\mathrm{j}}+\mathrm{e}_{\mathrm{ij}} \text {, onde: }
$$

$\mathrm{Y}_{\mathrm{ij}}=$ observação da progênie $\mathrm{i}$, no bloco $\mathrm{j}$;

$\mathrm{m}=$ média geral;

$\mathrm{p}_{\mathrm{i}}=$ efeito de progênies $\mathrm{i}$, aleatório

$b_{j}=$ efeito do bloco $j ; \quad(j=1,2 \ldots . r)$, aleatório

$\mathrm{e}_{\mathrm{ij}}=$ erro experimental; $\mathrm{e}_{\mathrm{ij}} \mathrm{N}\left(0, \sigma^{2}\right)$

Em seguida procedeu-se à análise conjunta dos ensaios de ambos os locais de acordo com o seguinte modelo :

$$
\mathrm{Y}_{\mathrm{ijk}}=\mathrm{m}+\mathrm{p}_{\mathrm{i}}+\mathrm{l}_{\mathrm{k}}+(\mathrm{pl})_{\mathrm{ik}}+\mathrm{b}_{\mathrm{j}(\mathrm{k})}+\mathrm{e}_{\mathrm{ijk}} \text {, onde }:
$$

$\mathrm{Y}_{\mathrm{ijk}}=$ observação da progênie $\mathrm{i}$, no bloco j, no local k

$\mathrm{m}=$ média geral;

$\mathrm{p}_{\mathrm{i}}=$ efeito de progênies $\mathrm{i}$, aleatório

$\mathrm{l}_{\mathrm{k}}=$ efeito do local $\mathrm{k}$, fixo

$(\mathrm{pl})_{\mathrm{ik}}=$ efeito da interação entre progênies i e local $\mathrm{k}$

$\mathrm{b}_{\mathrm{j}(\mathrm{k})}=$ efeito do bloco $\mathrm{j}$ no local $\mathrm{k}$, aleatório

$\mathrm{e}_{\mathrm{ijk}}=$ erro experimental; $\mathrm{e}_{\mathrm{ijk}} \mathrm{N}\left(0, \sigma^{2}\right)$

Os ensaios foram também analisados agrupando-os por subpopulação dentro de cada local. Desta maneira procedeu-se a análise agrupada utilizando-se o processo de médias ponderadas, tendo em vista que os graus de liberdade de cada fonte em cada ensaio eram diferentes.

O modelo matemático para tal análise é descrito como :

$$
Y_{i j k}=m+p_{i}(K)+E_{k}+b_{j}(k)+e_{i j k} \text {, onde : }
$$

$\mathrm{Y}_{\mathrm{ijk}}=$ observação da progênie $\mathrm{i}$, no bloco $\mathrm{j}$, no experimento $\mathrm{k}$ $\mathrm{m}=$ média geral;

$\mathrm{p}_{\mathrm{i}(\mathrm{k})}=$ efeito de progênies $\mathrm{i}$ dentro do experimento $\mathrm{k}$, aleatório $\mathrm{E}_{\mathrm{k}}=$ efeito de experimento local $\mathrm{k}$, aleatório 
$\mathrm{b}_{\mathrm{j}(\mathrm{k})}=$ efeito do bloco $\mathrm{j}$ no experimento $\mathrm{k}$, aleatório

$\mathrm{e}_{\mathrm{ijk}}=$ erro experimental; $\mathrm{e}_{\mathrm{ijk}} \mathrm{N}\left(0, \sigma^{2}\right)$

A seguir foi realizada a análise conjunta entre os mesmos agrupamentos de ambos os locais, conforme o modelo matemático descrito a seguir:

$$
\mathrm{Y}_{\mathrm{ijkl}}=\mathrm{m}+\mathrm{pi}(\mathrm{k})+\mathrm{b}_{\mathrm{j}(\mathrm{kl})}+\mathrm{pl}_{\mathrm{ik}(\mathrm{l})}+\mathrm{e}_{\mathrm{ijkl}} \text {, onde : }
$$

$\mathrm{Y}_{\mathrm{ijkl}}=$ observação da progênie $\mathrm{i}$, no bloco $\mathrm{j}$, no local $\mathrm{k}$, no experimento 1

$\mathrm{m}=$ média geral;

$\mathrm{p}_{\mathrm{i}(\mathrm{l})}=$ efeito de progênies i dentro do experimento l, aleatório

$\mathrm{b}_{\mathrm{j}(\mathrm{kl})}=$ efeito do bloco $\mathrm{j}$ no local $\mathrm{k}$, no experimento $\mathrm{l}$, aleatório

$\mathrm{e}_{\mathrm{ijk}}=$ erro experimental; $\mathrm{e}_{\mathrm{ijk}} \mathrm{N}\left(0, \sigma^{2}\right)$

O esquema da análise de variância agrupada por local é mostrado na tabela 05

\subsubsection{Estimativas de Parâmetros Genéticos}

A variância genética foi obtida ao nivel de médias de parcelas, à exceção do caráter peso de espigas, onde esta foi obtida ao nivel de totais de parcela. Posteriornente, os dados relativos ao peso de espigas foram transformados para gramas / planta.

Os parâmetros genéticos foram estimados para cada subpopulação dentro de cada local, através da análise agrupada de experimentos. As variâncias de cada efeito foram estimadas com base nas esperanças matemáticas dos quadrados médios, conforme descrito por MIRAND A FILHO (1974).

Tabela 05 : Esperança matemática dos quadrados médios (QM), para dados de médias ou totais de parcelas, com base na análise agrupada por local.

\begin{tabular}{lcccc}
\hline FV & GL & QM & E ( QM ) & F \\
\hline Experimentos & -- & -- & -- & \\
Blocos / Experimento & - & -- & -- & \\
Progênies / Experimento & $\mathrm{g} 1$ & $\mathrm{Q} 1$ & $\sigma_{e}^{2}+\mathrm{r} \sigma_{p}^{2}$ & $\mathrm{Q} 1 / \mathrm{Q} 2$ \\
Erro Médio & $\mathrm{g} 2$ & $\mathrm{Q} 2$ & $\sigma_{e}^{2}$ & \\
\hline
\end{tabular}


De acordo com a tabela 05 a variância genética entre progênies $\left(\sigma_{p}^{2}\right)$ foi obtida da seguinte maneira :

$$
\sigma_{p}^{2}=\frac{\mathrm{Q} 1-\mathrm{Q} 2}{\mathrm{r}}
$$

$\mathrm{Na}$ estimação da variância genética aditiva $\left(\sigma_{A}^{2}\right)$ para os caracteres com baixa dominância (AE, AP, NR, CP e PP), foi utilizada a hipótese $\sigma_{D}^{2}=0$; para o caráter peso de espigas, que apresenta alta dominância; foi utilizada a hipótese $\sigma_{D}^{2}=\sigma_{A}^{2}$. Portanto, para as progênies de IG onde $\sigma_{p}^{2}=1 / 2 \sigma_{A}^{2}+1 / 4 \sigma_{D}^{2}$ tem-se para os caracteres de baixa dominância, que $\sigma_{A}^{2}=2 \sigma_{I G}^{2}$, e para o caráter peso de espigas, $\sigma_{A}^{2}=4 / 3 \sigma_{I G}^{2}$. Em relação às progênies $S_{1}$, onde $\sigma_{p}^{2}=\sigma_{A}^{2}+{ }_{1 / 4} \sigma_{D}^{2}$, tem-se que, para os caracteres de baixa dominância, a $\sigma_{A}^{2}=\sigma_{S 1}^{2}$ e para o caráter peso de espigas a $\sigma_{A}^{2}=4 / 5 \sigma_{S 1}^{2}$.

A estimativa da herdabilidade ao nível de médias ou totais de parcelas foram obtidas através da seguinte equação:

$$
\mathrm{h}^{2} \mathrm{~m}=\frac{\sigma_{p}^{2}}{\sigma_{F}^{2}}
$$

onde :

$$
\sigma_{F}^{2}=\text { variância fenotípica entre médias ou totais de parcelas, obtida }
$$
da seguinte maneira :

$$
\begin{aligned}
& \sigma^{2} \quad \text { Q1 }
\end{aligned}
$$

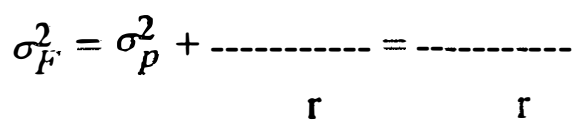

Também foram obtidas estimativas do coeficiente de variação genética (CVg) e do índice de variação b conforme descritos por VENCOVSKY (1978):

$\operatorname{CVg}(\%)=\frac{\sigma_{p}}{\mathrm{x}} \mathrm{x} 100$, onde :

$\sigma p=$ Desvio padrão populacional relativo à progênies $\mathrm{x}=$ Média populacional 
$\mathrm{CVg}$

Índice de variação $b=$----------------, onde :

$\mathrm{CVe}$

$\mathrm{CVg}=$ coeficiente de variação genético

$\mathrm{CVe}=$ coeficiente de variação experimental

\subsubsection{Covariâncias e Correlações}

As análises de covariância foram obtidas a partir das análises de variância conforme método descrito por KEMPTHORNE (1966), o qual utiliza a análise de variância de cada caráter individualmente $(\mathrm{x}$ e $\mathrm{y})$ e da soma dos dois $(\mathrm{u}=\mathrm{x}+\mathrm{y})$. Os produtos médios entre caracteres resultam dos quadrados médios das análises de variância realizadas como descrito a seguir:

QUADRADOS MÉDIOS ( QM ) PRODUTOS MÉDIOS

Progênies QMPx QMPy QMPu PMP x,y $=1 / 2(\mathrm{QMPu}-\mathrm{QMPx}-\mathrm{QMPy})$

Erro QMEx QMEy QMEu PME x,y $=1 / 2($ QMEu - QMEx - QMEy)

As variâncias e covariâncias foram calculadas a partir das análises agrupadas por subpopulacão dentro de cada local. Os esquemas das análises de covariância encontram-se na tabela 06 .

TABELA 06- Esperança matemática dos produtos médios obtidos na análise de covariância segundo o delineamento de blocos casualizados.

\begin{tabular}{llcc} 
FV & GL & PM & E ( PM ) \\
\hdashline Blocos & -- & - & - \\
Progênies & g1 & P1 & COVe + r COVp \\
Erro & g2 & P2 & COVe
\end{tabular}




$$
\begin{aligned}
& \text { As estimativas das covariâncias foram calculadas da seguinte forma : } \\
& \mathrm{COV}_{\mathrm{p}}=\frac{\mathrm{P}_{1}-\mathrm{P}_{2}}{\mathrm{r}}-\mathrm{COV}_{\mathrm{e}}=\mathrm{P}_{2} \\
& \mathrm{COV}_{\mathrm{F}}=\mathrm{COV}_{\mathrm{p}}+\underset{\mathrm{COV}}{\mathrm{C}}=\frac{\mathrm{Pl}}{\mathrm{r}}
\end{aligned}
$$

Uma vez obtidas as estimativas das variâncias e covariâncias genéticas e fenotípicas, foram obtidas as estimativas dos coeficientes de correlações genéticas $\left(r_{g}\right)$ e fenotípicas $\left(\mathrm{r}_{\mathrm{f}}\right)$, utilizando-se as seguintes fórmulas :

$$
r_{g}(x, y)=\frac{\operatorname{COVp}(x, y)}{\sigma_{p x} \cdot \sigma_{p y}} \quad \text { e } \quad r_{f}(x, y)=-\frac{\operatorname{COVf}(x, y)}{\sigma_{f} \mathrm{x} \cdot \sigma f y}
$$




\section{RESULTADOS E DISCUSSÃO}

\subsection{MÉDIAS POPULACIONAIS}

As médias das subpopulações de irmãos germanos (IG) e progênies $S_{1}$ são apresentadas por local (Tabela 07) para os caracteres avaliados, quais sejam : altura de espigas (AE), altura de planta (AP), número de ramificações do pendão (NR), peso de espigas (PE), comprimento do pendão (CP) e peso do pendão (PP). Pelos valores apresentados observou-se, comparando-se as médias das mesmas subpopulações nos dois locais, que à exceção do caráter $\mathrm{NR}$ em $\mathrm{R}+$ e E-, onde foi verificado uma superioridade das médias de Rio Verde em relação a Piracicaba, as médias dos caracteres avaliados apresentaram-se bastante próximas nas duas localidades.

A tabela 08 apresenta as médias dos caracteres AE, AP, NR, PE, CP e PP por subpopulação estudada no quinto ciclo (ARAÚJO, 1992) e sexto ciclo (média dos dois locais) de seleção divergente para NR e $\mathrm{AE}$, e a diferença relativa (DR \%) entre as médias das subpopulações divergentes. Considerando-se o caráter altura de espiga no presente ciclo (C6) e comparando-se as subpopulações divergentes para NR, observouse uma superioridade da subpopulação $R+$ em relação a $R$-, cujos valores foram de $110,63 \mathrm{~cm}$ e $89,51 \mathrm{~cm}$, respectivamente, e uma diferença relativa de 23,59\%. Apesar de ter sido o NR o caráter tomado como base para seleção nestas subpopulações, a $\mathrm{AE}$ também foi alterada, evidenciando assim uma resposta correlacionada positiva com o NR. O caráter AP apresentou um comportamento similar ao da $\mathrm{AE}$, porém menos pronunciado, exibindo valores médios de $199,46 \mathrm{~cm}$ e $188,53 \mathrm{~cm}$ para as subpopulações $\mathrm{R}+$ e $\mathrm{R}$-, respectivamente, e $5,79 \%$ de diferença relativa, o que concorda com OBILANA \& HALLAUER (1974), que afirmam que a associação do caráter NR é mais forte com a AE do que com a AP. Resultados semelhantes foram encontrados por ARAÚJO (1992) no quinto ciclo de seleção.

Quando o caráter $\mathrm{AE}$ foi tomado como base para a seleção, nas subpopulações E+ e E-, o efeito da divergência foi mais pronunciado, apresentando valores médios de $133,58 \mathrm{~cm}$ e $67,21 \mathrm{~cm}$, com uma diferença relativa de $98,75 \%$. Tal resultado era, de certa maneira, esperado tendo em vista o fato de ter sido a $\mathrm{AE}$ o caráter 
selecionado nestas subpopulações, e ser esse um caráter que apresenta alta resposta à seleção (PATERNIANI, 1967; ACOSTA e CRANE, 1970; ANDRADE, 1988). Nestas subpopulações a AP também apresentou uma alta diferença relativa entre as médias $(41,16 \%)$, com valores para as subpopulações E+ e E- de 229,42 cm e 162,52 cm, respectivamente, evidenciando a forte correlação positiva entre AE e AP (HALLAUER \& MIRANDA FILHO, 1988). A Figura 01 mostra a grande diferença (DR \%) verificada entre as subpopulações divergentes para AE para os caracteres AE e AP.

$\mathrm{O}$ caráter NR foi o que apresentou as médias mais divergentes entre todos os caracteres avaliados (Figura 02). Os valores médios de NR variaram de 39,05 para $\mathrm{R}+\mathrm{a}$ 8,16 para $\mathrm{R}_{\text {-, }}$ apresentando uma diferença relativa de $378,6 \%$ entre esses valores. Grandes progressos com seleção para NR também foram observados por diversos autores como PATERNIANI e GERALDI (1980), ANDRADE (1988) e ARAÚJO (1992). Mesmo em E+ e E-, onde o NR não foi o caráter selecionado, a diferença relativa foi de $40,04 \%$, com valores médios de 22,80 e 16,28 , respectivamente.

$\mathrm{O}$ caráter peso de espigas apresentou valores em $\mathrm{R}+\mathrm{e} \mathrm{R}$ - de $147,76 \mathrm{~g} / \mathrm{planta}$ $(7389,5 \mathrm{~kg} / \mathrm{ha})$ e $139,91 \mathrm{~g} /$ planta $(7006,5 \mathrm{~kg} / \mathrm{ha})$, respectivamente, e DR de 5,61\%. Esses dados concordam com ARAÚJO (1992), que encontrou pequena DR entre essas subpopulações no quinto ciclo de seleção. Uma grande diferença $(31,46 \%)$ foi observada para esse caráter entre E+ e E-, que apresentaram valores de 170,92 g/planta $(8546,0$ $\mathrm{kg} / \mathrm{ha})$ e $130,01 \mathrm{~g} /$ planta $(6500,5 \mathrm{~kg} / \mathrm{ha})$, respectivamente, corroborando com vários autores (LINDSEY et al., 1962; ACOSTA \& CRANE, 1972; LIMA \& PATERNIANI, 1977; RISSI, 1980; REGAZZI et al., 1982; ARAÚJO, 1992; LANDI \& FRASCORALI, 1993), sobre as correlações positivas entre AE e PE. Todas as subpopulações estudadas apresentaram PE inferiores à testemunha, o híbrido comercial G-85, que apresentou uma produtividade de $194,86 \mathrm{~g} /$ planta $(9743,0 \mathrm{~kg} / \mathrm{ha})$.

O caráter $\mathrm{CP}$ apresentou praticamente a mesma média nas duas subpopulações onde foi dimensionado, com valores de $42,03 \mathrm{~cm}$ e $41,81 \mathrm{~cm}$ para $\mathrm{R}+\mathrm{e}$ $\mathrm{R}$-, respectivamente, com uma diferença de apenas $0,52 \%$. Já o peso de pendão apresentou valores de 4,29 g e 3,81 g para $\mathrm{R}+$ e $\mathrm{R}$-, respectivamente, e uma DR de 12,59\%. GERALDI (1977) e ANDRADE (1988) observaram uma fraca associação entre CP e NR, ao contrário da forte associação positiva entre PP e NR relatada por ANDRADE (1988), o que está de acordo com os resultados do presente trabalho.

É importante salientar que, pelo fato de no presente trabalho não ter sido testada a população inicial (P0), não foi possível quantificar as magnitudes dos 
progressos com seleção nos dois sentidos, positivo e negativo. Podemos, no entanto, observando os resultados obtidos nos ciclos anteriores e no atual ciclo, tecer alguns comentários de importância prática. ARAÚJO (1992) observou que a seleção para menor NR diminuiu esse caráter e também a $\mathrm{AE}$, sem causar alterações na produção de grãos. No presente ciclo a produção nas duas subpopulações foi praticamente a mesma, sendo observado um DR de 23,59\% para AE (Figura 03), o que indica que uma seleção para menor NR pode diminuir a AE, melhorando assim a arquitetura da planta, sem prejuízos para a produção de grãos. Deve-se salientar ainda, que no presente projeto a seleção foi efetuada somente para um caráter em sua respectiva linha de seleção, sendo que, se na linha divergente R- a seleção fosse praticada também para produção poderiase, provavelmente, obter aumentos para esse caráter.

Embora não tenha sido possível quantificar as magnitudes dos progressos com seleção nos sentidos negativo e positivo, a comparação entre as diferenças do quinto e sexto ciclos é uma ferramenta para evidenciar a efetividade do processo de seleção divergente sobre os caracteres avaliados.

Pode-se observar para todos os caracteres, uma ampliação da divergência entre as médias das subpopulações divergentes do quinto para o sexto ciclo, indicando que a seleção está sendo efetiva na ampliação da divergência entre as médias dos caracteres estudados. Para o caráter AE a diferença evoluiu de $15,18 \%$ para $23,59 \%$ nas subpopulações selecionadas para NR, e de $81,08 \%$ para $98,75 \%$ nas selecionadas para AE. O caráter AP seguiu a mesma tendência do caráter $\mathrm{AE}$ em função da estreita associação entre esses dois caracteres.

O caráter NR apresentou uma evolução na diferença de 237,0\% para $378,30 \%$ nas subpopulações selecionadas para esse caráter, sendo esse o caráter que apresentou a maior resposta à seleção entre todos os caracteres avaliados. ANDRADE (1988), no terceiro ciclo de seleção na população ESALQ PB-1, relatou uma ampla variabilidade genética para NR, o que somado à alta herdabilidade apresentada pelo caráter (PATERNIANI \& GERALDI, 1980), explica a alta resposta à seleção obtida. Nas subpopulações selecionadas para AE, a diferença para o NR evoluiu de $17,7 \%$ no quinto ciclo para $40,04 \%$ no sexto ciclo, indicando também a presença de variabilidade genética e evidenciando os efeitos da resposta correlacionada ao caráter $\mathrm{AE}$.

$\mathrm{O}$ caráter PE apresentou uma diferença de $0,63 \%$ no quinto ciclo e de $5,41 \%$ no sexto ciclo nas subpopulações selecionadas para NR, e nas selecionadas para AE, a DR apresentada foi de $11,1 \%$ e $31,46 \%$ para o quinto e sexto ciclos, respectivamente. A 
superioridade em produção de $E+$ em relação à $E$ - foi também observada por ANDRADE (1988). Há que se ressaltar porém, a complexidade do caráter, pois reduções na altura de espiga sem reduções em $\mathrm{PE}$ já foram observadas por vários autores (MARECK \& GARDNER, 1979; PANDLEY et al., 1986).

As distribuições das médias para cada caráter dentro de cada subpopulação são apresentadas nas figuras 05 a 16. Estas foram organizadas por local e por caráter dentro de cada linha divergente, com o objetivo de uma melhor observação dos efeitos da seleção. Pode-se confirmar através das tabelas, que as maiores diferenças entre as médias foram verificadas para $\mathrm{AE}$ e NR nas respectivas linhas de seleção divergente, sendo observada para esses caracteres, uma grande diferença entre os valores extremos das linhas divergentes, indicando as grandes possibilidades de resposta na seleção no sentido de mudança das médias das linhas divergentes em sentidos opostos.

A tabela 09 apresenta as estimativas da depressão causada pela endogamia nas subpopulações $\mathrm{R}{ }^{+} \mathrm{S}$ e $\mathrm{R}-\mathrm{S}$. Para o caráter AE foi observada uma depressão de $10,02 \%$ para $\mathrm{R}^{+} \mathrm{S}$ e de $14,78 \%$ para $\mathrm{R}-\mathrm{S}$. O caráter AP apresentou valores para a depressão por endogamia na ordem de $18,92 \%$ e $17,54 \%$ para ${ }^{R}{ }^{+} S$ e $R-S$, respectivamente. Esses valores estão próximos às médias de depressão por endogamia para AE (15,62\%) e para AP (22,91\%) descritos por HALLAUER \& MIRANDA FILHO (1988), e dentro do intervalo relatado por LIMA et al. (1984), de 6,6\% a 20,3\% para altura de planta, e de 6,9\% a 27,4\% para altura de espigas. A Figura 04 mostra a depressão por endogamia para AP e AE.

Para NR foram encontrados valores de $17,3 \%$ para $\mathrm{R}-\mathrm{S}$ e de $9,33 \%$ para ${ }^{\mathrm{R}}{ }_{\mathrm{S}}$, estando próximos dos valores de 19,4\% e 12,7\% observados por NASS (1992), de $15,3 \%$ observado por KASSOUF \& MIRANDA FILHO (1984) e de $11,1 \%$ relatado por SAN VICENTE \& HALLAUER (1993). Como citado anteriormente, a quantificação dessa depressão para NR é importante pois, em um programa de produção de híbridos onde as linhagens são autofecundadas diversas vezes, em populações que possuam pouco NR, poderão ocorrer problemas relativos ao suprimento de pólen. Segundo STEBBINS (1957), a perda de vigor resultante da autofecundação em plantas de polinização cruzada é mais acentuada nas primeiras gerações e torna-se progressivamente menor nas gerações subseqüentes. Essa redução do vigor é devido aos genes recessivos de efeitos desfavoráveis presentes no conjunto gênico de uma determinada população e que estão mascarados pelos alelos dominantes em locos heterozigóticos. Os resultados obtidos neste trabalho mostram que em programas de 
produção de lúbridos, a utilização de linhagens com altos níveis de endogamia obtidas de populações que apresentam pouco NR, poderá causar problemas no tocante ao suprimento de pólen, em função da diminuição do NR decorrente da depressão por endogamia, tendo em vista que, na produção de híbridos utiliza-se normalmente uma proporção de 4 fileiras de plantas receptoras de pólen (fềmeas) para 1 fileira doadora de pólen (macho). No referido caso, as linhagens teriam que ser utilizadas como fêmeas. Porém, estudos mais detalhados sobre o assunto são necessários para obterem-se resultados conclusivos sobre o assunto. Vale ressaltar que as populações estudadas devem apresentar, provavelmente, valores de depressão menores que a população original, pois maiores alterações sobre a média do caráter são esperadas quando os alelos dominante e recessivo de um locos ocorrem com freqüências iguais $(p=q=0.5)$ na população (VELLO, 1984). Como as populações em estudo passaram por processo de seleção para maior e menor $\mathrm{NR}$, as mesmas devem apresentar uma alta freqüência de homozigotos para o caráter em questão.

\subsection{ANÁLISES DE VARJÂNCIA}

As tabelas 10 e 11 mostram os valores dos quadrados médios de progênies e do resíduo (erro médio) e dos coeficientes de variação experimental obtidos para cada caráter resultantes das análises agrupadas por subpopulação e por local.

Pode-se observar pela Tabela 10 que as subpopulações compostas de progênies autofecundadas apresentaram, à exceção dos caracteres $\mathrm{CP}$ e $\mathrm{PP}$ em $\mathrm{R}{ }^{+} \mathrm{S}$, $\mathrm{CVe}$ superiores às suas correspondentes $\mathrm{S}_{0}$ para todos os caracteres analisados. $\mathrm{A}$ elevação do CVe nessas subpopulações foi motivada pela menor média observada devido à depressão endogâmica e pelo aumento dos quadrados médios dos resíduos (erro médio), em conseqüência da maior sensibilidade dos indivíduos endogâmicos às variações do ambiente. Segundo FALCONER (1964), a causa da maior variância do ambiente nos individuos endogâmicos ainda não foi completamente esclarecida, mas sugere-se que o fato de os indivíduos possuírem alelos diferentes em locos específicos garante aos híbridos maior "versatilidade bioquímica", que os capacita a ajustar seus mecanismos fisiológicos e de desenvolvimento às circunstâncias do ambiente. Observouse ainda, um aumento nos quadrados médios de progênies, conseqüência da diferenciação genética entre linhas promovida pela endogamia. 
Para as demais subpopulações pode-se observar, comparando-se as tabelas 10 e 11, que os valores dos CVe para AE, AP e NR, caracteres avaliados em ambos os locais foram, de uma maneira geral, menores em Rio Verde, resultando assim em uma melhor precisão nesta localidade. Analisando-se os dois locais, observa-se que os CVe variaram de $7,94 \%$ a $18,72 \%$ para $\mathrm{AE}$, de $4,79 \%$ a $10,37 \%$ para $\mathrm{AP}$ e de $13,22 \%$ a $27,61 \%$ para NR. À exceção de AE e AP em E- e E+ respectivamente, ambos em Piracicaba, os valores observados para AP e AE estão dentro dos limites relatados na literatura (tabcla 02), que variam de 3,38\% à 9,21\% para AP e 2,48\% à $13,77 \%$ para AE. Em relação a NR, os CVe encontrados em Rio Verde, à exceção da subpopulação $\mathrm{R}$-, encontram-se também dentro dos limites relatados na literatura (Tabela 03), que variam de $9,44 \%$ à $16,37 \%$. Em Piracicaba, no entanto, as subpopulações R- e Eapresentaram valores considerados altos, com $27,61 \%$ e $25,56 \%$, respectivamente. $\mathrm{Na}$ comparação entre $\mathrm{CVe}$ deve-se atentar porém, para o fato dessas subpopulações ( $\mathrm{R}$ - e E-), apresentarem médias baixas para NR pelo efeito da seleção, o que provavelmente está influenciando os CVe no sentido de aumentá-lo, enquanto os dados relatados na literatura provêm de ensaios de materias com uma amplitude para NR de 18,10 a 31,00, superiores portanto, aos do presente ensaio (média de 14,25 para E- e 7,39 para R-). Considerando-se os valores de CVe encontrados para os caracteres AP, AE e NR, observa-se que os mesmos estão dentro ou próximos dos limites relatados na literatura e não foram, portanto, entraves para as análises estatísticas.

Os valores dos coeficientes de variação obtidos para $\mathrm{PE}$ oscilaram de $12,03 \%$ a 14,03\%. Em levantamento realizado por SOARES FILHO (1987), envolvendo 131 estimativas de CVe, observou-se uma média de 15,2\%, estando portanto os valores verificados no presente trabalho dentro dos limites da experimentação agrícola. Para os caracteres PP e CP, os valores variaram de 6,66 a $7,85 \%$ e de $3,00 \%$ a $8,20 \%$, respectivamente, similares aos obtidos por GERALDI (1977).

Os valores de $\mathrm{F}$ para o quadrado médio de progênies foram significativos a $1 \%$ para todos os caracteres na grande maioria das subpopulações, indicando a presença de variabilidade genética suficiente para obtenção de progressos na seleção, mesmo após os ciclos de seleção realizados. As exceções encontradas foram os caracteres AP e PE em $R$-, onde o teste $F$ foi significativo a $5 \%$ e os caracteres $A E$ em $R{ }^{+} S$ e PP em $R$-, onde não foram encontradas diferenças até $5 \%$ de probabilidade. No caso do caráter $\mathrm{AE}$ $\mathrm{em}^{\mathrm{R}}{ }_{\mathrm{S}}$, observou-se um valor muito alto para o erro médio, o que diminuiu a precisão experimental impossibilitando assim, a observação de diferenças significativas entre as 
progênies avaliadas. Para o caráter PP os resultados indicam a presença de pouca variabilidade genética em $\mathrm{R}$-, tendo em vista a boa precisão experimental observada nestes ensaios. Para esse caráter a seleção acarretaria pouco ou nenhum ganho.

A análise conjunta dos experimentos foi realizada entre experimentos de uma mesma subpopulação para os caracteres AP, AE e NR, sendo em seguida, realizado o agrupamento dessas análises por subpopulação (análise agrupada conjunta). As Tabelas 12 a 15 exibem as análises conjuntas por experimento dentro de cada subpopulação, e as análises agrupadas conjuntas por subpopulação são fornecidas na Tabela 16.

Pela Tabela 16 observa-se a significância a $1 \%$ de probabilidade para locais em todas as subpopulações e para todos os caracteres. As maiores diferenças entre locais demonstradas pelas análises estatísticas foram para o caráter NR, fato esse também relatado por ARAÚJO (1992), que observou significância entre locais para seis entre dez experimentos analisados. As interações LOC $*$ PROG mostraram-se não significativas, exceto para AP, AE e NR em R+, e para NR em E-. Esse fato indica uma certa facilidade na seleção no tocante à recomendação desses materiais para as duas localidades.

\subsection{PARÂMETROS GENÉTICOS}

Foram obtidas no presente estudo as estimativas da variância genética entre progênies $\left(\sigma_{G}^{2}\right)$, variância genética aditiva $\left(\sigma_{A}^{2}\right)$, variância fenotípica $\left(\sigma_{F}^{2}\right)$, herdabilidade $\left(\mathrm{h}^{2} \mathrm{~m}\right)$, coeficiente de variação genético $(\mathrm{CVg})$ e o índice $\mathrm{b}(\mathrm{CVg} \backslash \mathrm{CVe})$ ao nível de médias para cada caráter. Esses parâmetros genéticos foram estimados com base nas análises agrupadas por local e por subpopulação.

As Tabelas 17 e 18 fornecem as estimativas da $\sigma_{F}^{2}, \sigma_{G}^{2}$ e $\sigma_{A}^{2}$ encontradas em Piracicaba e Rio Verde, respectivamente. Comparando-se os dados obtidos para as mesmas subpopulações nestas duas localidades, observa-se, de uma maneira geral estimativas das $\sigma_{G}^{2}$ e $\sigma_{A}^{2}$ maiores em Rio Verde, conseqüência dos menores quadrados médios residuais observados nesta localidade em relação a Piracicaba. Esse fato indica uma maior precisão experimental refletidos nos menores CVe observados em Rio Verde, onde conseqüentemente tornou-se possível a melhor discriminação entre genótipos dentro de cada subpopulação, refletidos nas maiores estimativas das $\sigma_{G}^{2}$ e $\sigma_{A}^{2}$ encontradas nesta localidade. Também como conseqüência das maiores magnitudes dos erros médios encontradas em Piracicaba, as $\sigma_{F}^{2}$ neste local mostraram-se de uma maneira geral superiores as de Rio Verde. Segundo FALCONER (1964), a variância ambiental é 
uma fonte de erro que reduz a precisão dos estudos genéticos e o objetivo do pesquisador é, conseqüentemente, reduzi-la o máximo possível pelo manejo cuidadoso e delineamento apropriado do experimento.

Observa-se pela Tabela 17 que as subpopulações autofecundadas apresentaram estimativas de $\sigma_{G}^{2}$ superiores às suas correspondentes $\mathrm{S} 0$ em 8 entre as 10 estimativas observadas. Esses resultados concordam com FALCONER (1964), que ressalta que a endogamia conduz a um aumento da $\sigma_{G}^{2}$ e diminuição da variância dentro das progênies $\left(\sigma_{d}^{2}\right)$. Segundo PATERNIANI \& MIRANDA FILHO (1978), em função desse aumento da $\sigma_{G}^{2}$ seu uso é recomendado para a seleção de caracteres que apresentam baixa herdabilidade. Por outro lado, as estimativas da $\sigma_{F}^{2}$ nessas subpopulações também apresentaram-se muito altas, decorrente do aumento do erro médio, como conseqüência, segundo relatado anteriormente, da maior sensibilidade de progênies endogâmicas às variações ambientais. Esse fato é muito importante no sentido prático, pois a vantagem da seleção em progênies autofecundadas pela elevação do quadrado médio de progênies, pode ser compensada em experimentos não muito bem instalados e/ou conduzidos, pela excessiva elevação do erro experimental impedindo assim o aumento da $\sigma_{G}^{2}$ e a conseqüente facilidade na seleção dos genótipos.

Foram observadas grandes diferenças entre as estimativas obtidas para o mesmo caráter nas diferentes subpopulações, principalmente para aqueles tomados como base para a seleção. Portanto, as maiores diferenças foram observadas entre as estimativas obtidas para NR nas linhas divergentes $R+e$-, e para AE nas linhas divergentes $\mathrm{E}+$ e E-. Essa diferença entre as estimativas é devido, principalmente, aos diferentes valores médios obtidos, sendo que as maiores estimativas foram observadas, de uma maneira geral, nas subpopulações que apresentaram as maiores médias populacionais.

A tabela 19 apresenta as estimativas de herdabilidade dos caracteres avaliados obtidas por subpopulação e por local, e a média geral por caráter. É importante ressaltar que a média geral obtida não é definida como uma estimativa em si, mas serve como base para comparações pois, segundo FALCONER (1964), como a herdabilidade é uma propriedade não só do caráter, mas também da população, que é influenciada por fatores ambientais, o grau de herdabilidade é caracterizado através da média de vários dados acumulados de diversos genótipos em diversos ambientes. De acordo com os dados obtidos, observa-se estimativas de herdabilidade superiores em Rio Verde para todos os caracteres em conseqüência, como citado anteriormente, das maiores 
estimativas de $\sigma_{G}^{2}$ e menores estimativas de $\sigma_{I}^{2}$ observadas nesta localidade em relação a Piracicaba. Esse fato ressalta a importância da precisão experimental em trabalhos de seleção de genótipos. Na localidade de Rio Verde, onde foi obtida uma melhor precisão experimental (menores erros médios e coeficientes de variação), as estimativas de herdabilidade observadas foram maiores que em Piracicaba, e conseqüentemente serão também maiores as estimativas de progresso com seleção neste local. MARQUES (1988), trabalhando com populações de milho irradiadas, também verificou que os valores mais elevados de herdabilidade obtidos em seus trabalhos estavam associados aos menores coeficientes de variação experimental.

Avaliando-se os resultados obtidos, os mesmos podem ser resumidos da seguinte maneira:

\subsubsection{ALTURA DE ESPIGA E ALTURA DE PLANTA}

Pelas Tabela 17 e 18 observa-se que para as progênies de irmãos germanos (IG), as estimativas da $\sigma_{A}^{2}$ para o caráter $\mathrm{AE}$ variaram de 106,1990 a 231,0716 $(\mathrm{cm} / \text { planta })^{2}$ e de 134,3397 a 205,3384 (cm/planta) ${ }^{2}$ em Piracicaba e Rio Verde, respectivamente, e para AP as estimativas oscilaram entre 168,7889 e 262,6917 $(\mathrm{cm} / \text { planta })^{2}$ em Piracicaba e entre 168,3933 e 250,9330 (cm/planta) ${ }^{2}$ em Rio Verde, estando as mesmas próximas às observadas por ARAÚJO (1992), que variaram de 65,7604 a $189,8600(\mathrm{~cm} / \text { planta })^{2}$ para $\mathrm{AE}$, e entre 87,3700 e $290,5556(\mathrm{~cm} / \text { planta })^{2}$ para AP. Os valores encontrados para ambos os caracteres também aproximam-se das estimativas descritas por MORAES (1989), de 188,0 (cm/planta) ${ }^{2}$ para AE e 278 $(\mathrm{cm} / \text { planta })^{2}$ para AP obtidas através da média de 70 estimativas de populações de milho brasileiras. Os maiores valores da $\sigma_{A}^{2}$ para AE foram observadas em $\mathrm{E}+$ (Piracicaba) e $\mathrm{R}+$ (Rio Verde), e os menores em E- (Piracicaba) e em R- (Rio Verde). Para AP os maiores valores foram observados em $R-e$ em Piracicaba e Rio Verde, respectivamente, e os menores em E- em Piracicaba e em Rio Verde.

As subpopulações submetidas à autofecundação apresentaram valores da $\sigma_{G}^{2}$ superiores às correspondentes IG $\left(\mathrm{S}_{0}\right)$ para os dois caracteres em $\mathrm{R}-\mathrm{S}$, com estimativas para AE e AP de 103,5438 e 201,8747 (cm/planta) ${ }^{2}$, respectivamente. Em $\mathrm{R}^{+} \mathrm{S}$ entretanto, as estimativas mostraram-se inferiores às progênies de $\mathrm{IG}$ em $\mathrm{R}+$ para os dois caracteres, com valores de 34,7047 (cm/planta) ${ }^{2}$ para AE 123,1859 (cm/planta) ${ }^{2}$ para AP. Esse fato pode ser explicado pelo elevado erro experimental observado nestas 
subpopulações em relação às suas correspondentes $\mathrm{S}_{0}$, e pela influência dos desvios associados à variância entre progênies $S_{1}$. Segundo COCKERHAM (1983), $D_{1}$ é a covariância entre os efeitos aditivos e dominantes nos homozigotos e $\mathrm{D}_{2}$ é a variância dos efeitos de dominância nos homozigotos. Como $\mathrm{D}_{1}$ é uma covariância, este desvio pode ser positivo ou negativo; com $\mathrm{D}_{1}$ negativo é possível que a variância entre progênies $S_{1}$ seja inferior às obtidas com progênies não endógamas.

As estimativas de herdabilidade apresentadas na Tabela 19 mostram, como citado anteriormente, valores superiores em Rio Verde em relação à Piracicaba para todos os caracteres. Para AE as estimativas variaram de 0,4824 a 0,6201 em Piracicaba e de 0,5206 a 0,7914 em Rio Verde, e para AP os valores oscilaram de 0,3356 a 0,7456 em Piracicaba, e de 0,4733 a 0,8560 em Rio Verde, estando esses valores dentro do intervalo apresentado por MORAES (1989). Em ambos os locais as menores estimativas de $h^{2} m$ para AE foram obtidas em E+ e em E-, o mesmo acontecendo para o caráter AP, consequência de uma redução da variabilidade genética para $\mathrm{AE}$ nas subpopulações $\mathrm{E}-\mathrm{e}$ E+, onde esse caráter foi tomado como base para a seleção, e para AP por ser um caráter altamente correlacionado com a altura de espigas. Outro fator que poderia ter contribuido para a verificação de menores estimativas em E+ e E- foi o maior CVe observado nestas subpopulações em relação à $\mathrm{R}+\mathrm{e} \mathrm{R}$-; porém, como as diferenças entre os CVe dessas subpopulações dentro de cada local não foram grandes (Tabelas 05 e 06), podemos assumir que a influência deste fator nas estimativas $\mathrm{de}^{2} \mathrm{~m}$ foi pequena.

Para $\mathrm{AE}$ a média geral calculada foi de 0,5730 , enquanto que para $\mathrm{AP}$ o valor encontrado foi de 0,6499. Esses resultados estão próximos aos valores de herdabilidade obtidos por MORAES (1989) de 0,6314 e 0,6378 para AE e para AP, respectivamente, e confirmam a alta herdabilidade para ambos os caracteres relatada por diversos autores (MIRANDA FILHO et al. 1974; LIMA \& PATERNIANI, 1977; MIRANDA FILHO, 1978; GHINI \& MIRANDA FILHO, 1979; LORDELO, 1982; TOSELLO \& GERALDI, 1980; REGAZZI et al., 1982; SANTOS, 1985; KASSOUF \& MIRANDA FILHO, 1984; SAMPAIO, 1986; ARAÚJO 1992).

\subsubsection{CARACTERES DO PENDÃO}

Com relação ao caráter NR, as estimativas da $\sigma_{A}^{2}$ para as progênies de IG foram, respectivamente, de 17,1526 e 3,9832 (ramificações/planta) ${ }^{2}$ para as linhas $\mathrm{R}+\mathrm{e}$ R- nos ensaios de Piracicaba, e em Rio Verde os valores encontrados foram de 54,5548 
(ramificações/planta) $^{2}$ para $\mathrm{R}+$ e 7,8068 (ramificações/planta) ${ }^{2}$ para $\mathrm{R}-$. Nas linhas divergentes para $\mathrm{AE}$ os valores observados para as estimativas foram de 16,0745 e 15,6766 (ramificações/planta) $^{2}$ para E+ e E-, respectivamente, em Piracicaba e de 23,1744 e 19,3155 (ramificações/planta) ${ }^{2}$ para E+ e E-, respectivamente, em Rio Verde. ARAÚJO (1992), no quinto ciclo de seleção divergente da população ESALQ PB-1 encontrou valores da $\sigma_{A}^{2}$ de 3,8048 em R-, 50,689 em R+, 21,1066 em E- e 26,3272 (ramificações/planta) $^{2}$ em $\mathrm{E}+$, valores próximos aos encontrados em Rio Verde e superiores as de Piracicaba.

Comparando-se as estimativas da variância genética aditiva $\left(\sigma_{A}^{2}\right)$ obtidas neste trabalho com a estimativa média de quinze populações (Tabela 03), de 21,17 (ramificações/planta) ${ }^{2}$ obtidas por diversos autores no Departamento de Genética da ESALQ, verifica-se, à exceção da subpopulação $R-$, a presença de suficiente variabilidade genética para obtenção de progressos com seleção. Quanto à subpopulação R-, deve-se atentar porém, para o fato da mesma ter sido selecionada para menor NR e apresentar, conseqüentemente, valores médios muito baixos para esse caráter, o que torna dificil a comparação com as demais populações, pois médias baixas tendem a diminuir os valores da $\sigma_{A}^{2}$.

Para o caráter comprimento de pendão foram observadas estimativas da $\sigma_{A}^{2}$ que oscilaram de 3,6326 a $11,8804(\mathrm{~cm} / \text { planta })^{2}$, próximas às obtidas por GERALDI (1977), que observou valores de 5,9468 à 15,4242 (cm/planta $)^{2}$. Estimativas baixas da $\sigma_{A}^{2}$ (g/planta) $)^{2}$ foram observadas para o caráter PP nas linhas divergentes para NR, que variaram de 0,0026 a 0,0256, bastante inferiores aos observados por GERALDI (1977), que variaram de 1,12 a 2,7 . Essas estimativas refletem a baixa variabilidade genética presente nessas subpopulações para o referido caráter.

Pelos dados de $\mathrm{h}^{2} \mathrm{~m}$ obtidos, verifica-se que para o caráter NR, as mesmas variaram de 0,4928 a 0,6391 em Piracicaba e de 0,6617 a 0,7735 em Rio Verde alcançando uma média geral de 0,6434 . Não foram verificados no entanto, ao contrário dos caracteres AE e AP, diferenças nas estimativas entre as linhas de seleção divergente (NR e AE) em ambos os locais. Isto é uma evidência da presença após os seis ciclos de seleção, de elevada variabilidade genética para NR em todas as subpopulações estudadas, mesmo em $\mathrm{R}+\mathrm{e} \mathrm{R}$ - onde foi esse o caráter tomado como base para a seleção. As estimativas observadas no presente estudo estão acima das obtidas por GERALDI (1977), que trabalhando com três populações de milho observou em média estimativas 
de $h_{2} m$ na ordem de 0,458 e próximas aos valores obtidos por diversos autores (Tabela $03)$, onde a média observada foi de 0,6844.

Os caracteres CP e PP apresentaram coeficientes de herdabilidade variando de baixos a relativamente altos, sendo estes, em média, de 0,6365 e 0,4690 para CP e PP, respectivamente, superiores aos obtidos por GERALDI (1977), de 0,2800 para CP e 0,3610 para PP. Para PP no entanto, as estimativas de $h^{2} \mathrm{~m}$ observadas em $\mathrm{R}+(0,3047)$ e $\mathrm{R}$ - $(0,2294)$ foram baixas, devido à reduzida $\sigma_{G}^{2}$ verificada para o caráter; estimativas mais elevadas foram observadas em $\mathrm{R}+\mathrm{s}$ e $\mathrm{R}$-s em conseqüência, conforme salientado por FALCONER (1964), do aumento da $\sigma_{G}^{2}$ devido à autofecundação. As baixas estimativas de herdabilidade assim como os baixos valores da $\sigma_{G}^{2}$ encontrados para PP em $\mathrm{R}+\mathrm{e} \mathrm{R}$ - indicam poucas possibilidades de alteração da média dessas populações para esse caráter. Por outro lado as altas estimativas obtidas para NR e CP indicam que a seleção fenotípica pode ser eficiente no melhoramento de tais caracteres, principalmente para NR, por ser este um caráter de fácil visualização ao nível de campo.

\subsubsection{PESO DE ESPIGAS}

As estimativas da $\sigma_{A}^{2}$ para PE (g/planta) ${ }^{2}$ mostraram um intervalo de variação também bastante amplo. Foram observadas estimativas na ordem de 88,7362 para $\mathrm{R}+$, 46,1455 para $\mathrm{R}$-, 27,3375 para E+ e 40,5683 para E-. Os valores encontrados estão dentro do intervalo de variação da $\sigma_{A}^{2}$ para PE apresentado por VENCOVSKY et al. (1988), que vai de 41 a 753 (g/planta) ${ }^{2}$, porém abaixo da média de 309 (g/planta $)^{2}$ apresentada pelos autores. Os valores apresentados pelos autores são relativos a 58 ensaios conduzidos no Brasil. ARAÚJO (1992), encontrou valores da $\sigma_{A}^{2}$ para PE para as mesmas subpopulações avaliadas no presente trabalho porém no ciclo anterior

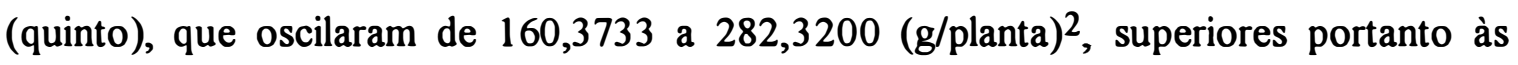
obtidas no presente ciclo.

As estimativas de $h_{2}$ m obtidas para o caráter PE oscilaram de 0,0966 a 0,1610, alcançando uma média de 0,2407, mostrando-se bastante baixas quando comparadas com os dados obtidos no ciclo anterior por ARAÚJO (1992), que observou um valor médio geral de 0,6026 para a herdabilidade desse caráter.

A comparação entre as diferentes populações estudadas em relação à variabilidade genética existente através das estimativas da $\sigma_{A}^{2}$ tornou-se dificil, pelo fato dessas populações apresentarem diferentes médias populacionais, principalmente para os 
caracteres tomados como base para seleção (NR e AE). A utilização do coeficiente de variação genético $(\mathrm{CVg})$, cujas estimativas indicam a quantidade de variação genética entre progênies em relação à média populacional, é segundo VENCOVSKY (1978), limitado para a comparação de diferentes populações por depender da média do caráter em questão. Apesar deste coeficiente ser dependente da média da população em estudo, vários autores utilizaram-no como indicador do potencial genético de populações (LIMA \& PATERNIANI, 1977; ZIMBACK, 1985; MARQUES, 1988; BIGOTO, 1988; SILVEIRA et al., 1991)

Segundo VENCOVSKY (1978), para contornar tal problema é necessária a utilização do índice de variação genético (b), o qual expressa a proporção da variação genética em relação à variação ambiental, além de eliminar a influência da média populacional nas comparações entre diferentes populações. Ainda segundo o autor, além de ser utilizado na comparação da variabilidade genética, este índice serve para indicar se os materiais genéticos, numa determinada fase de avaliação se prestam à seleção, sendo que quando esse coeficiente atinge o valor $1.0 \mathrm{ou}$ mais, indica uma situação muito fàvorável à seleção.

A Tabela 20 apresenta as estimativas do $\mathrm{CVg}$ e do índice de variação b para os caracteres AE, AP e NR obtidas nas duas localidades e para PE, CP e PP obtidas em Piracicaba. De uma maneira geral, não foi observada uma relação direta entre o $\mathrm{CVg}$ e o b, sendo que as maiores discrepâncias entre as duas estimativas foram verificadas para os caracteres que apresentaram médias populacionais mais contrastantes, quais sejam : NR e AE nas respectivas linhas de seleção, o que concorda com RAMALHO (1977), que relata que as diferenças nas médias das populações prejudicam a utilização do coeficiente de variação genético para a comparação da variabilidade genética presente em diferentes populações ou ciclos.

Comparando-se os dados dos dois locais, verifica-se ainda que os maiores indices de variação b foram observados em Rio Verde, onde a precisão experimental foi superior à verificada em Piracicaba e por conseqüência, onde foram verificados os menores coeficientes de variação experimental e as maiores estimativas de $\sigma_{G}^{2}$ e de herdabilidade. Tal associação também foi verificada por MARQUES (1988). Apesar de ter a vantagem de eliminar o efeito de médias populacionais, os resultados observados neste trabalho sugerem que comparações de indices de variação entre experimentos com niveis de precisão experimental diferentes, devem ser feitas com ressalvas, atentando-se sempre para esse fato. 
As estimativas do $\mathrm{CVg}$ e do $\mathrm{b}$ verificadas nas subpopulações $\mathrm{S}_{1}$ mostraramse superiores às suas correspondentes $S_{(0)}$, à exceção das estimativas do índice $b$ para $A E$ em $\mathrm{R}^{+} \mathrm{S}$ e para AP em R+${ }_{S}$ e $\mathrm{R}_{-}$, confirmando a alta capacidade de liberação de variância genética que possuem as progênies autofecundadas (HALLAUER \& MIRANDA FILHO, 1988). No caso das três subpopulações citadas acima, as menores estimativas de $\mathrm{CVg}$ e de $\mathrm{b}$ observadas foram decorrentes do maior erro experimental verificadas nestas subpopulações em relação às suas corrrespondentes $\mathrm{S}_{0}$.

Considerando-se os dois locais, as estimativas para o $\mathrm{CVg}$ variaram de 7,34 a 13,31 com uma média de 9,38 para $\mathrm{AE}$ e de 4,37 a 8,90 com média de 5,87 para AP. Os valores de b oscilaram de 0,55 a 1,18 com média de 0,77 para $\mathrm{AE}$ e de 0,40 a 1,11 com média de 0,79 para AP. Considerando-se as subpopulações $\mathrm{S}_{0}$, para os dois caracteres e em ambos os locais, os maiores valores para o $\mathrm{CVg}$ foram observados nas subpopulações que apresentaram as menores médias populacionais para o caráter, $\mathrm{R}-\mathrm{e}$ E-. Como o $\mathrm{CVg}$ é definido como o quociente entre o desvio padrão genético e a média populacional, as menores médias observadas em $\mathrm{R}$ - e E- elevaram o $\mathrm{CVg}$ nestas subpopulações. No caso do índice b, como o efeito das médias é eliminado, não observase nenhuma correlação entre esses valores e as médias populacionais. De uma maneira geral as estimativas encontram-se dentro do intervalo compilado por MORAES (1989), que verificou em um total de 22 estimativas em populações brasileiras de milho, valores para o $\mathrm{CVg}$ que oscilaram de 3,14 a 10,34 para $\mathrm{AE}$ e de 2,03 a 8,07 para AP e estimativas de b que variaram de 0,36 a 0,99 para $\mathrm{AE}$ e de 0,31 a 0,88 para AP. Nesse levantamento os valores médios do CVg observados para AE e AP foram de 6,68 e 4,44, respectivamente, e para $\mathrm{b}$ verificou-se valores médios de 0,70 para $\mathrm{AE}$ e de 0,64 para AE. Em termos médios portanto, os valores observados no presente estudo para os dois parâmetros genéticos e para os dois caracteres apresentaram-se superiores aos verificados por MORAES (1989), evidenciando assim a presença de variabilidade genética suficiente para a obtenção de progressos com seleção nas subpopulações estudadas para ambos os caracteres .

Para os caráter NR foram observados valores médios para as estimativas do $\mathrm{CVg}$ e do índice b de 17,85 e 0,85 , respectivamente, com as subpopulações $\mathrm{S}_{1}$ apresentando, para ambos os parâmetros, valores superiores às suas correspondentes $\mathrm{S}_{0}$. Os valores obtidos encontram-se próximos aos descritos na Tabela 03, que apresentam uma média de 12,19 para o $\mathrm{CVg}$ e de 0,90 para o índice $\mathrm{b}$. Tendo em vista o fato das subpopulações aqui avaliadas terem passado por seis ciclos de seleção, as mesmas ainda 
apresentam grande variabilidade genética, fato esse também observado por ANDRADE (1988) no terceiro ciclo e ARAÚJO (1992), no quinto ciclo de seleção.

$\mathrm{O}$ caráter $\mathrm{CP}$ apresentou, em média, valores para o $\mathrm{CVg}$ de 5,32 e para o indice $b$ a média observada foi de 0,74 . Para PP os valores médios observados foram de 1,85 e 0,51 para o $\mathrm{CVg}$ e índice $b$, respectivamente, sendo esse o caráter que apresentou as mais baixas estimativas entre todos os caracteres avaliados. GERALDI (1975), analisando esse caráter, observou em média para três populações estudadas valores para o coeficiente de variação genética de 2,5. 0 mesmo autor verificou nas mesmas populações um valor médio do $\mathrm{CVg}$ para PP na ordem de 9,5 , bastante superiores ao valor médio observado no presente trabalho $(1,85)$. Tomando como base esses parâmetros, pode-se dizer portanto, que o caráter CP é geneticamente bem variável, enquanto que o PP tem pouca variação genética.

Os valores do $\mathrm{CVg}$ para o caráter $\mathrm{PE}$ variaram de 2,64 a 5,52, estando os mesmos dentro do intervalo relatado por RAMALHO (1977), que foi de 3,37 a 15,31. TORRES SEGÓVIA (1976), estudando a variedade Centralmex, de base ampla, obteve uma variação nas estimativas do $\mathrm{CVg}$ após seis ciclos de seleção entre progênies de meios irmãos, de 4,41 a 7,13, superiores aos valores aqui obtidos. SANTOS (1985), avaliando a população ESALQ PB-1 e duas populações semi-exóticas de milho obteve valores para as estimativas do $\mathrm{CVg}$ de 3,95, 5,83 e 8,31, respectivamente. Portanto, os valores aqui obtidos encontram-se dentro daqueles reportados na literatura. Da mesma forma os valores obtidos para o indice $b$, que variaram de 0,31 a 0,45, situam-se bem próximos aos relatados por vários autores, entre eles SANTOS (1985), que obteve valores de 0,28 a 0,55, BIGOTO (1988), que observou valores que variaram de 0,19 a 0,41 e GERALDI (1975), que verificou para esse parâmetro valores de 0,37, em média, para três populações estudadas. Segundo o último autor citado, para PE, este índice está em média, em torno de 0,45 para os experimentos conduzidos no Departamento de Genética da ESALQ, sendo que nestas situações tem-se conseguido progressos com seleção para o caráter.

Conforme relatado anteriormente, a utilização do $\mathrm{CVg}$ é limitada para a comparação de diferentes populações por depender da média do caráter em questão, sendo utilizado como indicador do potencial genético de populações. A Tabela 21 apresenta os valores do $\mathrm{CVg}$ e do índice de variação $b$ para os caracteres $\mathrm{AE}, \mathrm{AP}, \mathrm{NR}$ e $P E$ no presente ciclo e no ciclo inicial $P_{0}$. As comparações da variabilidade relativa do presente ciclo com o ciclo inicial serão efetuadas tomando-se como base o indice b, pelas 
razões anteriormente expostas, sendo que os valores do $\mathrm{CVg}$ estão apresentados nesta Tabela com o intuito de novamente observar a influência da média populacional nos valores desse parâmetro. Pode-se observar que, principalmente para os caracteres tomados como base para a seleção, $\mathrm{AE}$ e $\mathrm{NR}$, as estimativas do $\mathrm{CVg}$ apresentam valores inconsistentes, sendo que as subpopulações E- e R-, as quais apresentaram menores médias populacionais apresentaram também maiores valores para o $\mathrm{CVg}$, tornando assim as comparações dificeis de serem realizadas. As estimativas do indice b, por sua vez, apresentaram valores consistentes pelo fato de eliminar a influência das médias populacionais.

Para o caráter $\mathrm{AE}$ verificou-se uma queda na variabilidade genética nas subpopulações do ciclo atual em relação ao ciclo inicial $P_{0}$, que apresentou um índice de 1,06. No presente ciclo, os resultados obtidos foram de 0,82 para $R+$ e $R-$ e de 0,64 e 0,79 para E+ e E-, respectivamente. Os menores valores apresentados em E+ e E- foram decorrentes do fato de que nessas linhas, o caráter $\mathrm{AE}$ ter sido tomado como base para a seleção. Nas linhas de seleção para NR (R+e R-), o declínio da variabilidade genética expresso pelo índice $b$ foi menos acentuada devido a $\mathrm{AE}$ ser um caráter fracamente correlacionado com o NR, fato esse relatado por ANDRADE (1988), ARAÚJO (1992) e também neste estudo (Tabela 22).

Por outro lado, nas linhas de seleção para NR não foi observado declínio na variabilidade genética para o caráter $A P$, onde as estimativas para $b$ foram de 1,06 e 1,03 para $R+$ e $R$-, respectivamente, enquanto que $P_{0}$ apresentou uma valor de 1,02. ANDRADE (1988) e ARAÚJO (1992) em seus estudos com a população ESALQ PB-1, objeto desse estudo, relatam que o caráter NR é mais fracamente correlacionado à AP do que à $\mathrm{AE}$, fato esse confirmado no presente trabalho (Tabela 22), o que explica a manutenção da variação genética para $\mathrm{AP}$, ao contrário da pequena queda verificada em AE. Nas linhas divergentes para AE, por sua vez, foi verificada uma acentuada queda na variação genética para $\mathrm{AP}$, em conseqüência da alta associação entre esses dois caracteres. Entretanto os valores do índice b para AP nessas subpopulações apresentaram-se inferiores aos de $\mathrm{AE}$, o que não era esperado tendo em vista ter sido $\mathrm{AE}$ o caráter selecionado nessas linhas.

O número de ramificações do pendão foi, entre todos os caracteres avaliados, o que apresentou as menores reduções em termos de variabilidade genética. Em R+e R-, os índices verificados foram de 0,84 e 0,87 , respectivamente, bem próximos ao valor observado para $P_{0}(0,92)$. Mesmo tendo sido o $N R$ o caráter selecionado nessas 
subpopulações, a alteração na variabilidade expressa pelo índice b foi mínima. Apesar de ser um caráter correlacionado com a AE (OBILANA \& HALLAUER, 1977; ANDRADE \& MIRANDA FILHO, 1980; LORDELO, 1982; AGUILAR MORAN, 1984 ; SAMPAIO, 1986; AYALA OSUMA et al., 1986; SOARES FILHO, 1987, ARAÚJO, 1992), o caráter NR não apresentou nenhuma redução na variabilidade genética nas linhas divergentes para $\mathrm{AE}$, onde foram verificados valores para $\mathrm{b}$ de 0,90 em E+ e de 0,91 em R-, similares ao valor observado em $P_{0}$. KASSOUF \& MIRANDA FILHO (1984), relataram uma ampla variabilidade genética para NR na população ESALQ PB-1, fato esse também observado por ANDRADE (1988) no terceiro ciclo de seleção divergente para esse caráter e ARAÚJO (1992) no quinto ciclo desta seleção. Os resultados aqui verificados revelam que após o sexto ciclo de seleção, as subpopulações estudadas praticamente não sofreram alterações ao nível de variação genética para NR, apresentando, como na população inicial, ampla variabilidade genética para o caráter. Esse fato pode ser confirmado observando-se o intervalo de variação da distribuição de médias (Figuras 11 a 13).

$O$ caráter $P E$ apresentou em $P_{0}$ um índice b de 0,84 , tendo este valor sofrido uma drástica redução no presente ciclo em todas as subpopulações estudadas, apesar de não ter sido esse o caráter utilizado na seleção. Os valores verificados em $R+e \mathrm{R}$ - foram de 0,45 e 0,31 , respectivamente, enquanto que nas linhas divergentes para $\mathrm{AE}$ os valores obtidos foram de 0,18 em E+ e 0,33 em E-. Redução na variação genética para o caráter PE foi verificada por SILVEIRA et al. (1991), que relataram uma queda nos valores do índice b de 0,99 para 0,24 após apenas um ciclo de seleção recorrente. Por outro lado diversos autores (LONNQUIST et al., 1966; MOLL \& ROBINSON, 1966; HALLAUER, 1970, entre outros), não observaram reduções na variabilidade genética para PE após vários ciclos de seleção.

SILVA \& LONNQUIST (1968) relatam que a alteração da variabilidade genética de um caráter é dependente da freqüência gênica, do grau de dominância, da intensidade de seleção e do número de indivíduos selecionados para a próxima geração. Tendo em vista o grande número de índivíduos selecionados nas subpopulações estudadas (em média em torno de 30 por ciclo) e o fato de que intensidades de seleção semelhantes às usadas neste trabalho (em torno de 15 a 20\%) não causarem, segundo SILVEIRA et al. (1991), alterações muito drásticas na variabilidade genética, pode-se supor que as reduções na variação genética de PE aqui observadas, possam ser decorrentes do fato desse caráter ser correlacionado com AE (ANDRADE, 1988; 
ARAÚJO, 1992) e também com NR (ANDRADE, 1988). Embora no presente trabalho, as correlações estimadas entre PE e $\mathrm{AE}$ e entre Pe e NR tenham alcançado valores considerados de médios a médios (Tabela 22), essa associação poderia ao longo dos ciclos de seleção para $\mathrm{AE}$, ter causado alterações na variabilidade de $\mathrm{PE}$.

De uma maneira geral, verificou-se portanto, que apesar de algumas reduções na variabilidade de alguns caracteres em determinadas subpopulações, estas ainda apresentam suficiente variabilidade genética para a obtenção de sucesso em futuras seleções.

\subsection{CORRELAÇÕES ENTRE CARACTERES}

A Tabela 22 apresenta as correlações genéticas (rg) e fenotípicas ( $\mathrm{rf}$ ) por população e por local, entre todos os caracteres avaliados. É feita então, a seguir, uma abordagem resumida sobre os resultados obtidos.

I- Correlações entre altura de espiga (AE) e altura de planta (AP)

Os coeficientes de correlação rg e rf estimados entre esses caracteres foram os de maiores magnitudes entre todas as associações estudadas. Os valores verificados nos dois locais apresentaram-se bastante próximos, embora tenha-se verificado na localidade de Rio Verde valores um pouco superiores aos de Piracicaba. Também não foram observadas grandes diferenças nas estimativas entre as populações avaliadas. Analisando-se os dois locais, observa-se que os valores de rg oscilaram de 0,7553 a 0,8702 , com uma média de 0,8005 , enquanto que para if os valores variaram de 0,6746 a 0,9114 , alcançando uma média de 0,77799 .

De acordo com os dados compilados por MORAES (1989), para populações de milho brasileiras os coeficientes de correlação genética e fenotípica apresentaram médias de 0,82 e 0,78, respectivamente. HALLAUER \& MIRANDA FILHO (1988), relataram uma alta correlação positiva entre os dois caracteres, citando um valor médio para rg, baseado em diversas estimativas, na ordem de 0,81. ANDRADE \& MIRANDA FILHO (1980) avaliando a população ESALQ PB-1, encontraram valores de rg e rf de 0,84 e 0,67 , respectivamente. Os valores verificados no presente trabalho encontram-se portanto, próximos aos valores reportados na literatura. 
II- Correlações entre altura de espiga $(\mathrm{AE})$ e número de ramificą̧ões do pendão (NR) e entre altura de planta (AP) e NR

Os valores estimados revelaram uma fraca associação tanto entre $A E$ e NR, quanto entre AP e NR. Verifica-se, entretanto, que as estimativas de rg e rf entre AE e $\mathrm{NR}$, embora baixas, apresentaram valores superiores às correlações entre AP e NR, concordando assim com os valores apresentados na Tabela 04, que através de resultados de vários autores descreve uma maior associação entre AE e NR do que entre AP e NR.

Os valores médios estimados para rg e rf entre AE e NR foram de 0,2299 e 0,2407, respectivamente. ANDRADE \& MIRANDA FILHO (1980), avaliando a população ESALQ PB-1, verificaram valores de rg e rf entre esses dois caracteres na ordem de 0,1990 e 0,2040, respectivamente. ARAÚJO (1992), avaliando essa mesma população no quinto ciclo de seleção divergente observou valores de 0,1778 para rg e de 0,1110 para rf. Os valores verificados no presente trabalho mostram-se assim similares aos valores anteriormente citados e também aos valores reportados na Tabela 04, que através de resultados de diversos autores revela valores para as correlações genética e fenotípica na ordem de 0,1080 e 0,2400, respectivamente.

Para a associação entre AP e NR os valores das correlações genéticas e fenotípicas foram em média de 0,08204 e 0,1464, respectivamente. Assim como a associação entre AE e NR, os valores de rg e rf entre AP e NR encontram-se bem próximos aos reportados na literatura. A Tabela 04 apresenta valores de $\mathrm{rg}$ e rf entre esses dois caracteres na ordem de 0,0540 e 0,1380 , respectivamente, enquanto que ARAÚJO (1992), observou valores para rg e rf de 0,0130 e 0,0176, respectivamente.

III- Correlações entre altura de espiga (AE) e peso de espigas (PE) e entre altura de planta (AP) e PE

Os valores de rg e rf entre $\mathrm{AE}$ e PE não tiveram uma grande variação entre as subpopulações, o mesmo acontecendo entre AP e PE à exceção de R- que mostrou valores inferiores às demais subpopulações em ambas as associações, fato esse também observado por ARAÚJO (1992), no quinto ciclo de seleção.

Os valores de rg e rf obtidos entre AE e PE podem ser considerados de baixos à médios, alcançando valores médios de 0,3403 e 0,2416 para $\mathrm{rg}$ e if, 
respectivamente. Estes valores assemelham-se aos observados por ARAÚJO (1992), de 0,3545 para rg e 0,3237 para if.

As estimativas calculadas de $\mathrm{rg}$ e $\mathrm{rf}$ entre AP e PE apresentaram valores inferiores aos obtidos entre $\mathrm{AE}$ e $\mathrm{PE}$, com valores médios de 0,2139 para $\mathrm{rg}$ e 0,2429 para rf. Assim como na associação entre $\mathrm{AE}$ e $\mathrm{PE}$, não foram observadas grandes variações entre as subpopulações estudadas, exceção podendo ser feita a $R$ - que apresentou valores de $\mathrm{rg}$ e rf de 0,0874 e 0,1500, respectivamente. A exemplo da associação entre $\mathrm{AE}$ e $\mathrm{PE}$, os dados aqui obtidos são bastante similares aos reportados na literatura, como os compilados por MORAES (1989), que mostraram uma correlação genética de 0,320 e uma correlação fenotípica de 0,270 e também aos observados por ARAÚJO (1992), que obteve estimativas de rg e rf na ordem de 0,4270 e 0,3870, respectivamente.

IV- Correlações entre número de ramificações do pendão (NR) e peso de espigas (PE)

De acordo com as valores de rg e rf apresentados, observa-se uma fraca associação entre esses caracteres, com os valores dos coeficientes de correlação genética oscilando de -0,0218 em R+ a 0,4561 em R-, alcançando uma média de 0,1948, enquanto que os coeficientes de correlação fenotípicas variaram de 0,0095 a 0,2868, com média de 0,1593 . Os valores aqui verificados são superiores aos apresentados na Tabela 04 que através de resultados de diversos autores mostra uma média de $-0,1970$ para rg e 0,0460 para rf.

Os valores obtidos neste ciclo de seleção foram similares aos obtidos no ciclo anterior por ARAÚJO (1992), que também verificou valores negativos em $\mathrm{R}+\mathrm{e}$ positivos em R-. Segundo esse autor, tais valores estão de acordo com FALCONER (1964), de que o processo de seleção pode levar a uma inversão das correlações entre os caracteres. Os valores de $\mathrm{rg}$ e rf positivos verificados em $\mathrm{R}$ - podem ser explicados observando-se o ponto de vista fisiológico, argumento também utilizado por ARAÚJO (1992). Nessa subpopulação a média de NR foi extremamente baixa (7,39 pendões/ planta) e é possível que as plantas que apresentaram menores NR possam ser desbalanceadas fisiologicamente ou mais homozigóticas, e portanto, menos produtivas. Em função desse fato, dentro dessa subpopulação as plantas com maior NR seriam assim mais balanceadas e em conseqüência mais produtivas. As correlações negativas 
verificadas em $\mathrm{R}+$ podem ser explicadas de maneira semelhante, ou seja, pelo desbalanceamento fisiológico das plantas com um grande NR fazendo com que as plantas com menor NR exibissem uma maior produtividade. As linhas divergentes para $\mathrm{AE}$ apresentaram valores similares para as correlações, alcançando valores de 0,2078 para $\mathrm{rg}$ e 0,223 I para rf em E+ e 0,1373 para rg e 0,2868 para rf em E-.

É importante salientar que a associação entre esses dois caracteres é muito dependente das condições ambientais sendo que, segundo SOARES FILHO (1987), em ambientes favoráveis à cultura do milho tais associações podem ser positivas sendo, ao contrário, tanto mais negativas quanto menos adequadas forem as condições de cultivo. No caso especifico deste trabalho, pode-se considerar que as condições de clima foram favoráveis durante todo o ciclo, assim como foram realizados todos os tratos culturais recomendados para a cultura.

IV- Correlações entre comprimento de pendão (CP) e os demais caracteres e entre peso de pendão (PP) e os demais caracteres

As associações entre o caráter CP e os demais caracteres apresentaram uma grande variação entre as subpopulações estudadas, mostrando dados inconsistentes e conseqüentemente dificeis de serem interpretados. Apesar de ter sido observada variabilidade genética através da análise agrupada, provavelmente os valores verificados para esse caráter dentro de cada subpopulações não foram suficientemente contrastantes para se determinar com segurança os coeficientes de correlações genética e fenotípica entre este e os demais caracteres. Fato semelhante foi observado por LIMA NETO (1994), que devido à baixa variabilidade genética observada para o caráter prolificidade, verificou também valores inconsistentes para rg e rf entre esse caráter e o caráter produção de grãos.

Fato semelhante foi observado para as correlações entre PP e os demais caracteres. Para esse caráter foi verificada pouca variabilidade genética nas subpopulações avaliadas, impossibilitando assim a deteminação das correlações. A distribuição de freqüências das médias apresentadas nas figuras 15 e 16 confirmam a pouca variação genética observada para o caráter. 


\section{CONCLUSÕES}

Os resultados obtidos no presente estudo permitem relacionar as seguintes conclusões:

- As maiores diferenças entre as médias populacionais das subpopulações divergentes foram verificadas para os caracteres tomados como base para a selę̧ão, $\mathrm{AE}$ e NR, em suas respectivas linhas de seleção.

- Após seis ciclos de seleção divergente para NR e AE, foi observada, em relação ao quinto ciclo, uma ampliação da diferença entre as médias nas subpopulações divergentes para os caracteres $\mathrm{AE}, \mathrm{AP}$ e NR, evidenciando que a seleção está sendo efetiva na alteração das médias populacionais.

- Verificou-se para todos os caracteres, à exceção de PP, a presença de suficiente variabilidade genética para a obtenção de progressos com seleção, principalmente para NR.

- As estimativas de variância genética entre progênies, obtidas com progênies endogâmicas apresentaram-se superiores às suas correspondentes não endógamas para todos os caracteres, à exceção de AE e AP na linha de seleção R+.

- As interações entre genótipos e ambientes mostraram-se não significativas, à exceção de $\mathrm{AP}$ e $\mathrm{AE}$ em R+, e NR em R+ e E-. Esse fato indica uma certa facilidade na seleção no tocante à recomendação desses materiais para as duas localidades.

- Com base nas estimativas do índice b, conclui-se que após os seis ciclos de seleção, os maiores decréscimos na variabilidade genética, em relação a população original, ocorreram para o caráter PE. Verificou-se ainda, uma queda na variabilidade 
genética para $\mathrm{AE}$ nas linhas onde esse caráter foi tomado como base para a seleção (E+e E-), o mesmo ocorrendo para AP, em conseqüência da estreita associação entre esses dois caracteres, evidenciando-se assim os efeitos da resposta correlacionada à seleção. A variabilidade genética manteve-se inalterada para $N R$ nas linhas divergentes para $A E$, sofrendo apenas um pequeno decréscimo em $\mathrm{R}+\mathrm{e} \mathrm{R}$-, evidenciando a alta variabilidade para esse caráter presente nas subpopulações estudadas.

- As correlações entre AE e AP mostraram-se as mais elevadas, não apresentando modificações em relação aos ciclos anteriores. As correlações entre NR e $\mathrm{AE}$ mostraram-se de baixas à médias, sendo um pouco superiores às observadas entre NR e AP.

- Sob o ponto de vista prático, as subpopulações R- e E- são as mais promissoras para utilização em programas de melhoramento, objetivando reduções no porte da planta e no número de ramificações do pendão, respectivamente.

- Sob o ponto de vista teórico o trabalho deve continuar, com o objetivo de um maior estudo da estrutura genética e do comportamento de cada subpopulação ao longo dos ciclos de seleção. 


\section{REFERÊNCIAS BIBLIOGRÁFICAS}

ACOSTA, AE. \& CRANE, P.L. Further selection for lower ear height in maize. Crop Science, Madison, 12: 165-7, 1972.

AGUILAR MORAN, J.F. Avaliação do potencial genético de linhagens e respectivos testadores obtidos de duas populações de milho (Zea mays L.). Piracicaba, 1984, 118 p. (Mestrado-Escola Superior de Agricultura "Luiz de Queiroz "/ USP).

ALLEN, F.L.; COMSTOCH, R.E.; RASMUSSON, D.C. Optimun environments for yield testing. Crop Science, Madison, 18: 747-51, 1978.

ANDERSON, I.C. Plant characteristics that affect yield. Procedings of the 22th. Annual Hybrid and Corn Industry-Research Conference. Washington, 1967, 22: 71-3.

ANDERSON, I.C. Possible pratical applications of chemical pollen control in corn and sorghum seed production. In : ANNUAL HYBRID CORN INDUSTRYRESEARCH CONFERENCE, 26, Chicago, 1971. American Seed Trade Association, p 22-6.

ANDRADE, J.A.C. Seleção divergente para tamanho do pendão e posição relativa da espiga na população ESALQ PB-1 de milho (Zea mays L.). Piracicaba, 1988136 p. (Mestrado-Escola Superior de Agricultura "Luiz de Queiroz"/USP).

ANDRADE, J.A.C. \& MIRANDA FILHO, J.B. Estimativas de parâmetros para os caracteres de pendão na população ESALQ PB-1 de milho. Relatório Científico Departamento de Genética. ESALQ/USP. Piracicaba, 14: 5-10, 1979.

ANDRADE, J.A.C. \& MIRANDA FILHO, J.B. Correlações genéticas e fenotípicas envolvendo caracteres da planta e do pendão de milho. Relatório Científico Departamento de Genética. ESALQ/USP. Piracicaba, 14: 5-10, 1980. 
ANDRADE, J.A.C. \& MIRANDA FILHO, J.B., GERALDI, 1.0 \& SOUZA Jr.,C.L. Seleção divergente para número de ramificações do pendão e altura de espigas na população ESALQ PB-1. de milho. IN: CONGRESSO NACIONAL DE MILHO E SORGO, 16. Sete Lagoas, 1986. Resumos. Sete Lagoas, EMBRAPACNPMS. p. 57-8.

ARAÚJO, P.M. Variabilidade genética em subpopulações de milho (Zea mays L.) obtidas por seleção divergente. Piracicaba, 1992. 153 p. (Mestrado-Escola Superior de Agricultura "Luiz de Queiroz "/USP).

AYALA OSUMA, J. ; ARAÚJO, S.M.C.; BANZATO, D.A Avaliação do tamanho do pendão em relação à alguns caracteres agronômicos em duas populações de milho. In : CONGRESSO NACIONAL DE MILHO E SORGO, 15., Maceió, 1984. Anais. Brasília, EMBRAPA/DDT, 1986, P. 147-51.

BIGOTO, C.A. Estudo da população ESALQ PB-1 de milho (Zea mays L.) em cinco ciclos de seleção recorrente. Piracicaba, 1988. 124 p. (Mestrado-Escola Superior de Agricultura "Luiz de Queiroz"/USP).

BRUCE, R.R.; SANFORD, J.O.; HYHRE, D.L. Soil water and nitrogen influence on growth and fruiting of a citoplasmic male-sterile corn hybrid and its fertile counterpart. Agronomy Journal, New York, 58: 631-4, 1966.

BRUNINI, O.; ALFONSI, R.R; PAES DE CAMARGO, M.B. Efeito dos elementos clináticos no desenvolvimento da cultura do milho. In : SIMPÓSIO SOBRE PRODUTIVIDADE DO MILHO - SPM., Londrina, 1983. Anais. Londrina, IAPAR, 1983. p. 21-40.

BUREN, L.L; MOCK, J.J; ANDERSON, I.C. Morphological traits in maize associated with tolerance to high plant density. Crop Science, Madison, 14: 26-9, 1974.

BURGESS, J.C. \& WEST, D.R. Selection for grain yield following selection for ear height in maize. Crop Science, Madison, 33: 679-82, 1993.

CHINWUBA, P.M.; GROGAN, C.O.; ANDERSON, I.C. Morphological and phisiological traits in maize associated with tolerance to high plant density. Crop Science, Madison, 1: 279-80, 1961. 
CIMMYT. Maiz - mejoramento genético. Informe Annual del Cimmyt, Chapingo, p. 94-103, 1972.

COCKERHAM, C.C. An extension of the concept of partitioning hereditary variance for analysis of covariance among relatives when epistasis is present. Genetics, Princeton, 39: 859-82, 1954.

COCKERHAM, C.C. Effects of linkage on the covariances between relatives. Genetics, Princeton, 41: 138-41, 1956.

COCKERHAM, C.C. Implications of genetic variances in a hybrid breeding program. Crop Science, Madison, 1: 47-52, 1961.

COCKERHAM, C.C. Estimation of genetic variances. In : HANSON, W.D. \& ROBINSON, H.F. Statitical genetics and plant breeding. NAS - NRC, 982: 5393, 1963.

COCKERHAM, C.C. Covariance of relatives from self-fertilization. Crop Science, Madison, 23: 1170-80, 1983.

COCKERHAM, C.C. \& WEIR, B.S. Descent measures for two loci with some applications. Theor. pop. biol., 4: 300-30, 1973.

COMPTON, W.A. \& BAHADUR, K. Ten cycles of progress from modified ear to row selection in corn (Zea mays L.). Crop Science, Madison, 17: 378-80, 1977.

COMPTON, W.A. \& LONNQUIST, J.H. A multiplicative selection index to four cycles of full-sib recurrent selection in maize. Crop Science, Madison, 22: 981-3, 1982.

COMSTOCK, R.E. \& ROBINSON, H.F. The components of genetic variance in populations of biparental progenies and their use in estimating the average degree of dominance. Biometrics, Raleigh, 4: 254-66, 1948.

COMSTOCK, R.E. \& ROBINSON, H.F. Estimation of average dominance of genes. IN: GOWEN, J.W., Ed. Heterosis. Ames, Iowa State College Press, p. 494-516, 1952. 
CORTEZ-MENDOZA, H. \& HALLAUER, A.R. Divergent mass selection for ear lenght in maize. Crop Science, Madison, 19: 175-8, 1979.

CRISÓSTOMO, J.R. Estimação de parâmetros genéticos visando seleção em dois compostos de milho (Zea mays L.) Piracicaba, 1978. 71 p. (Mestrado-Escola Superior de Agricultura "Luiz de Queiroz"/USP).

CRISWELL, J.G.; HUME, D.J.; TANNER, J.W. Effect of cytoplasmic male-sterilly on acumulation and translocation of $\mathrm{C}^{14}$ - labelled assimilates in corn. Crop Science, Madison, 14: 252-4, 1974.

CROSS, H.Z.; CHYLE, J.R. \& HAMMOND, J.J. Divergent selection for ear moisture in early maize. Crop Science, Madison, 27: 914-8, 1987.

CUNHA, M.A.P. Seleção entre e dentro de familias de meios-irmão de milho (Zea mays L). Piracicaba, 1976. 84 p. (Doutorado-Escola Superior de Agricultura "Luiz de Queiroz"/USP)

DARRAH, L.L.; EBERHART, S.A.; PENNY, L.H. A maize breeding methods study in Kenya. Crop Science, Madison, 12: 605-8, 1972.

DONALD,C.M. The breeding of crop ideotypes. Euphytica, Wageningen, 17: 385-403, 1968.

DUDLEY, J.W. Seventy generations of selection for oil and protein percentage in maize. In: International Conference of Quantitative Genetics, 1.,1977, Procedings. Ames, Iowa State University Press. p 455-73.

DUDLEY, J.W. \& LAMBERT, R.J. Genetic variability after 65 generations of selection in Illinois high oil, low oil, high protein, and low protein strains of Zea mays $\mathrm{L}$. Crop Science, Madison, 99: 179-81, 1969.

DUDLEY, J.W.; LAMBERT, R.J.; ALEXANDER, D.R. Seventy generations of selection for oil and protein concentration in the maize Kernel. In: DUDLEY, J.W ED: Seventy Generations of Selection for Oil and Protein in Maize. Madison, Crop Science Society of America, 1974, Corp. 9. 181-221. 
DUDLEY, J.W.\& LAMBERT, R.J. Ninety generations of selection for oil and protein in maize. Maydica, Bergamo, 37: 81-4, 1992.

DUNCAN, W.G.; WILLIANS, W.A.; LOOMIS, R.S. Tassels and the productivity of maize. Crop Science, Madison, 7: 37-9, 1967.

DUNGAN, G.H. \& WOODWORTH, C.M. Loss resulting from pulling leaves with tassels in detasseling corn. Agronomy Journal, New York, 31: 372-5, 1939.

DUVICK, D.N. Yield and other agronomic characteristics of citoplasm male sterilly corn hybrids compared to their normal counterparts. Agronomy Journal, New York, 50: $121-25,1958$.

EASTEN, J.A. C-1 4 labeled photosynthate export from fully expanded corn (Zea mays L) leaf blades. Crop Science, Madison, 10: 425-8, 1970.

EDMEADES, G.O.; FAIREY, N.A. \& DAYNARD, T.B. Influence of plant density on the distribuition of $\mathrm{C}$ labelled assimilate in maize at flowering. Canadian Journal Plant Science, Ottawa, 59: 577-84. 1979.

FAKOREDE, M.A.B.\& MOCK, J.J. Changes in morphological and physiological traits associated with recurrent selection for grain yield in maize. Euphytica, Wageningen, 27: 397-409, 1978.

FALCONER, D.S. Introduction to quantitative genetics. 2 ed., New York, Ronald Press, 365 p., 1964.

FEHR, W.R. Principles of cultivar developtment. Macmillan, New York 6: 628-68, 1987.

FISHER, R.A. The correlations between relatives on the supposition of Mendelian inheritance. Trans. Roy. Soc., 52: 399-433, 1918. 
FISHER, K.S.; EDMEADS, G.O.; JOHNSON, E.C. Recurrent selection for reduced tassel number and reduced leaf area density above the ear in tropical maize populations. Crop Science, Madison, 6: 1150-59, 1987.

GARDNER, C.O. An evaluation of effects of mass selection and seed irradiation with thermal neutrons on yield of corn. Crop Science, Madison, 1: 241-245, 1961.

GARDNER, C.O. The role of mass selection and mutagenic treatment in modern corn breeding. Procedure of the 24th Annual Corn and Sorghum Research Conference,p. 15-21, 1966.

GARDNER, C.O. Quantitative genetic studies and population improvement in maize and sorghum. Nebraska Agric. Expt. Sta. Bull, Nebraska, : 5262, 15 p., 1977.

GARDNER, C.O. \& LONNQUIST, J.H. Linkage and the degree of dominance of genes controlling quantitative characters in maize. Agronomy Journal, Madison, 51: 524-28, 1959.

GARDNER, C.O.; HARVEY, P.H.; COMSTOCK, R.E.; ROBINSON, H.F. Dominance of genes controlling quantitative characters in maize. Agronomy Journal, Madison, 45: 186-91, 1953.

GENTER, C.F. Mass selection in a composite of intercrosses of mexican races of maize. Crop Science, Madison, 16: 556-8, 1976.

GERALDI, I.O. Estimação de parâmetros genéticos de caracteres do pendão (Zea mays L.) e perspectivas de melhoramento. Piracicaba, 1977, 103 p (Mestrado-Escola Superior de Agricultura "Luiz de Queiroz " /USP).

GERALDI, I.O; MIRANDA FILHO, J.B.; VENCOVSKY, R. Estimates of genetics parameters for tassel characters in maize (Zea mays L.) and breeding perspectives. Maydica, Bergamo, 30: 1-14, 1985.

GHINI, R. \& MIRANDA FILHO, J.B. Herdabilidade da altura da planta e da espiga no segundo ciclo de seleção da população ESALQ PB-1 de milho. Relatório Científico Departamento de Genética. ESALQ/USP. Piracicaba, 13: 130-7,1979. 
GIESBRECHT, J. The inheritance of ear height in Zea mays L. Canadian Journal of Genetics and Cytology, Quebec, 3: 26-33, 1961.

GOODMAN, M.M. Estimates of genetic variance in adapted and exotic populations of maize. Crop Science, Madison, 5: 87-90, 1965.

GROGAN, C.O. Detasseling responses in corn. Agronomy Journal, New York, 48: 247-9, 1956.

HALLAUER, A.R. Genetic variability for yield after four cycles of reciprocal recurrent selection in maize. Crop Science, Madison, 10: 482-85, 1970.

HALLAUER, A.R. Change in genetic variance for seven plant and ear traits after four cycles of reciprocal recurrent selection for yield in maize. Iowa State Journal of Science, Ames, 45: 575-93, 1971.

HALLAUER, A.R. Relation of quantitative genetics to applied maize breeding. Revista Brasileira de Genética, Ribeirão Preto, 3: 207-33, 1980.

HALlAUER, A.R. Selection and Breeding methods. In: FREY, K.J., ed. Plant Breeding II. Ames, Iowa State University Press, 1981. Cap 1, p. 3-55.

HALLAUER, A.R. \& MIRANDA FILHO, J.B. Quantitative Genetics in Maize Breeding. The Iowa State University Press. Ames, Iowa, 1988, 468p 2 ed.

HARLAND, S.C. A new method of maize improvement. Tropical Agriculture, 23: 114, 1946.

HARTUNG, R.C. Divergent phenotypic recurrent selection for filling period duration rate in maize. Dissertation Abstracts International, Ann. Arbor, 45 (4): 108 2b 108 3b, 1984.

HULL, F.H. Recurrent selection and specific combining ability in corn. J. Am. Soc. Agron., 37: 134-145, 1945. 
HUNTER, R.B.; DAYNARD, T.B.; HUME, D.J.; TANNER. J.W.; CURTIS. J.O. \& KANNENBERG, L.W. Effect of tassel removal on grain yield of corn (Zea mays L) Crop Science, Madison, 9: 405-6, 1969.

HUNTER, R.B.; MORTIMORE, G.G. \& KANNENBERG, L.W. Inbred maize performance following tassel and leaf removal. Agronomy Journal, New York, 65: 471-2, 1973.

JOSEPHSON, L.M. \& KINCER, H.C. Selection for lower placement in two synthetic populations of maize. Crop Science, Madison, 17: 499-502, 1977.

JOSEPHSON, L.M. \& KINCER, H.C. Effects of male-sterile cytoplasm on yields and agronomic characteristics of corn inbreds and hybrids. Crop Science, Madison, 2: 41-3, 1962.

KASSOUF , A.L. \& MIRANDA FILHO, J.B. Variabilidade e endogamia na população de milho ESALQ PB-1. In: Congresso Nacional de Milho e Sorgo, 15, Maceió, 1984. Anais, Brasilia, Departamento de Difusão de Tecnologia, 1986 p. 119-31.

KEMPTHORNE, $\mathrm{O}$. The correlation between relatives in a random mating population. Proc. Roy. Soc., London, 143: 103-13, 1945.

KEMPTHORNE, $\mathrm{O}$. The theoritical values of correlations between relatives in a random mating populations. Genetics, Princeton, 40: 153-67, 1955.

KEMPTHORNE, O. An introduction to Genetical Statistics. New York. John Wiley and Sons, Inc. 545 p., 1966.

KIESSELBACH, T.A. Developtment and structure of the reproductive organs. In: The structure and reproduction of corn. (Research bulletin n. 161) Nebraska Agricultural Experiment Station, University of Nebraska, 1949. cap. 4 p. 37.57.

LAMBERT, R.J. \& JOHNSON, R.R. Leaf angle, tassel morphology, and the performance of maize hybrid. Crop Science, Madison 18: 499-502, 1978. 
LANDI, P.\& FRASCAROLI, E. Response to four cycles of full-sib family recurrent selection in an $\mathrm{F}_{2}$ maize population. Maydica, Bergamo, 1: 31-37, 1993.

LANKLEY, K.R. \& HALLAUER, A.R. Fifty cycles of recurrent selection in the Iowa Stiff Stalk Synthetic maize population. Maydica, Bergamo, 37: 19-27, 1992.

LAVENDOVSKY, I.M.F. Alocação diferencial de recursos em populações de milho (Zea mays L.). Piracicaba, 1987, 87 p. (Mestrado-Escola Superior de Agricultura "Luiz de Queiroz "/ USP).

LEONARD, W.A. \& KIESSELBACH, T.A. The effect of the removal of tassels on the yield of corn. Agronomy Journal, Madison, 24: 514-16, 1932.

LERNER, I·M. The genetics basis of selection. New York, John Wiley and Sons, 1958, $298 \mathrm{p}$.

LIMA, M.; FURLANI, P.R.; MIRANDA FILHO, J.B. Divergent selection for aluminum tolerance in a maize (Zea mays L.) population. Maydica, Bergamo, 37: 123-32, 1992.

LIMA, M. ; MIRANDA FILHO, J·B.; GALLO, P.B. Inbreeding depression in brazilian populations of maize (Zea mays L.). Maydica, Bergamo, 29: 203-15, 1984.

LIMA, M. \& PATERNIANI, E. Estimativas de parâmetros genéticos e fenotípicos em progênies de meios-irmãos de milho (Zea mays L.) ESALQ VD-2 MI - HSIII e suas implicações no melhoramento. Relatório Científico do Departamento de Genética ESALQ/USP. Piracicaba, 11: 84-9, 1977.

LIMA NETO, F.P. Número de progênies para estimação de parâmetros genéticos em milho (Zea mays L.). Piracicaba, 1994124 p. (Mestrado-Escola Superior de Agricultura "Luiz de Queiróz"/USP).

LINDSEY, M.F.; LONNQUIST, J.H.; GARDNER, C.O. Estimates of genetic variance in open - pollinated varieties of corn belt maize. Crop Science, Madison, 2: 105$108,1962$. 
LONNQUIST, J.H. Progress from recurrent selection procedures for the improvement of corn populations. Crop Science, Madison, 4: 227-228, 1961.

LONNQUIST, J.H. Progress from recurrent selection procedures for the improvement of corn population. Nebraska Agricultural Exp. Est. Research bulletin 197, $1961,33 \mathrm{p}$.

LONNQUIST, J.H. Mass selection for prolificacy in maize. Der Zucther, Berlim, 37: 185-8, 1967.

LONNQUIST, J.H.; COTA, O.A.; GARDNER, C.O. Effect of mass selection and thermal neutron irradiation on genetic variances in a variety of corn (Zea mays $\mathbf{L}$.). Crop Science, Madison, 6: 330-2,1966.

LORDELO, J.A.C. Parâmetros genéticos das populações de milho Piranão VD - 2 e Piranão VF - 1. Piracicaba, 1982. 63 p. (Mestrado-Escola Superior de Agricultura "Luiz de Queiroz "/ USP).

LORDELO, J.A.C. \& MIRANDA FILHO. J·B. Correlações genéticas e fenotípicas entre caracteres em duas populações de milho braquitico. Relatório Científico do Departamento de Genética. ESALQ/USP, 1981. Piracicaba, 15: 104-8.

MAGALHÃES, A.C. \& SILVA, W.J. Determinantes genéticos-fisiológicos da produtividade do milho. In: PATERNIANI, E. e G.P. VIEGAS eds. Melhoramento e produção do milho, Fundação Cargill, Campinas, 1987, cap 11 p 423-50.

MARECK, J.H. \& GARDNER, C.O. Response to mass selection in maize and stability of resulting population. Crop Science, Madison, 19: 779-83, 1979.

MARQUES, J·R.B. Seleção recorrente com endogamia em duas populações de milho (Zea mays L.). Piracicaba, 1987. 151 p. (Mestrado-Escola Superior de Agricultura "Luiz de Queiroz"/USP). 
MARTINS, C. Potencial genético de linhagens e híbridos de duas populações de milho (Zea mays L.) braquítico. Piracicaba, 1986. 143 p. (Doutorado-Escola Superior de Agricultura "Luiz de Queiroz "/USP).

MIRANDA FILHO, J.B. Cruzamentos dialélicos e sintese de compostos de milho (Zea mays L.) com ênfase na produtividade e no porte da planta. Piracicaba, $1974116 \mathrm{p}$. (Doutorado-Escola Superior de Agricultura "Luiz de Queiroz "/USP).

MIRANDA FILHO, J.B. Herdabilidade da altura da planta e da espiga na população ESALQ PB-1. Relatório Científico do Instituto de Genética, ESALQ/USP. Piracicaba, 12: 116-21, 1978.

MIRANDA FILHO, J.B.; PATERNIANI, E.; VENCOVSKY, R. Variância genética aditiva da altura da planta e da espiga em dois compostos de milho e sua aplicação no melhoramento. Relatório Científico do Instituto de Genética, ESALQ/USP. Piracicaba, 8: 104-8, 1974.

MOCK, J.J. \& SCHUETZ, S.H. Inheritance of tassel branch number in maize. Crop Science, Madison, 14: 885-8, 1974.

MOCK, J.J. \& PEARCE, R.B. An ideotype of maize. Euphytica, Wageningen, 24: 613$23,1975$.

MOLL, R.H. Sixteen cycles of recurrent full-sibfamily selection for grain weight in two maize populations. Crop Science, Madison, 4: 959-64, 1991.

MOLL, R.H. \& ROBINSON, H.F. Observed and expected response in four selection experiments in maize. Crop Science, Madison, 6: 319-23, 1966.

MOLL, R.H. \& STUBER, C.W. Comparisions of response of to alternative selection procedures initiated with two population of maize. (Zea mays $L_{\text {. }}$ ). Crop Science, Madison, 11: 706-11, 1971.

MORAES, M.L.T. Estimativas de parâmetros genéticos para os caracteres : Produção de grãos, altura de planta e altura de espiga em população de milho. Piracicaba, Depto. de genética / ESALQ, 198940 p. (monografia ). 
NASS, L.L. Variabilidade genética de populações semi-exóticas de milho (Zea mays L.). Piracicaba, 1992. 141 p. (Doutorado-Escola Superior de Agricultura "Luiz de Queiroz "/USP).

OBILANA, A.T. \& HALLAUER, A.R. Estimating of variability of quantitative traits in BSSS by using unselected maize inbred lines. Crop Science, Madison, 14: 99-103, 1974.

OBILANA, A.T. \& HALLAUER, A.R. Comparisions of estimates of genetics variability in Iowa Stiff Stalk Syntthetic of maize. Maydica, Bergamo, 22: 159-72, 1977.

OCHUNG, J.A.W. \& KAMADI, R.E. Response of eight cycles of recurrent selection in Kitale Synthetic II Ecuador 573 on their variety cross. Journal of genetics and Breeding, 46: 315-19, 1992.

ODHIAMBO, M.O. \& COMPTON, W.A. Twenty cicles of divergent mass selection for seed size in corn. Crop Science, Madison, 27: 1113-6, 1987.

PANDEY, S.; DIALLO, A. O.; ISLAM, T.M.T.; DEUSTCH, J. Progress from selection in eight tropical maize populations using international testing. Crop Science, Madison, 13: 371-6, 1973.

PATERNIANI, E. Selection among and within half-sib families in a brazilian population of maize. (Zea mays L.). Crop Science, Madison, 7: 212-16, 1967.

PATERNIANI, E. Avaliação do método de seleção entre e dentro de famílias de meiosirmãos no melhoramento do milho (Zea mays L.). Piracicaba, 1968. 92 p.(Tese de Professor Catedrático - Escola Superior de Agricultura "Luiz de Queiroz"/ USP)

PATERNIANI, E. Selection for reproductive isolation between two populations of maize, (Zea mays L.). Evolution, Kansas, 23: 534-47, 1969.

PATERNIANI, E. Origem e comportamento do milho Piranão. Relatório Científico do Instituto de Genética, ESALQ/USP. Piracicaba, 8: 104-8, 1974. 
PATERNIANI, E. Avaliação de cultivares de milho de planta baixa. Relatório Científico do Instituto de Genética, ESALQ/USP. Piracicaba, 12: 162-7, 1978.

PATERNIANI, E. Seleção massal no controle biparental para prolificidade em milho. Relatório Científico Departamento de Genética, ESALQ/USP. Piracicaba, 14 : 69-76, 1980.

PATERNIANI, E. Influence of tassel size on ear placement in maize.(Zea mays L.). - Maydica, Bergamo, 26: 85-91, 1981.

PATERNIANI, E. \& GERALDI, I.O. Seleção para redução do tamanho do pendão em duas variedades de milho braquítico. Relatório Científico do Departamento de Genética,ESALQ/USP. Piracicaba, 14: 97-104; 1980.

PATERNIANI, E. \& MIRANDA FILHO, J.B. Melhoramento de populações. In: PATERNIANI, E., Coord. Melhoramento e produção do Milho no Brasil. Piracicaba, ESALQ/USP, p. 202-56, 1978.

PENNY, L.H.; RUSSEL, W.A. \& SPRAGUE, G.F. Types of gene action in yield heterosis in maize. Crop Science, Madison, 2: 341-4, 1962.

POMMER, C.V. \& GERALDI, I.O. Selection among and within half-sib in two maize opaco populations. Revista Brasileira de Genética, Ribeirão Preto, 1983.

POZAR, G. Interação da arquitetura de planta e espaçamento na produtividade do milho (Zea mays L.) e suas implicações no melhoramento. Piracicaba, 1981. 75 p. (Mestrado-Escola Superior de Agricultura "Luiz de Queiroz "/ USP ).

QUEIROZ, M.A. Correlações genéticas e fenotípicas em progênies de meios-irmãos de milho (Zea mays L.) e suas implicações no melhoramento. Piracicaba, 1969. 71 p. (Mestrado-Escola Superior de Agricultura Luiz de Queiroz "/USP ).

RAMALHO, M.A.P. Eficiência relativa de alguns processos de seleção intrapopulacional no milho baseados em famílias não endógamas. Piracicaba, 1977. 122 p.(Doutorado-Escola Superior de Agricultura "Luiz de Queiroz "/USP). 
REDDY, B.S.; DHILLON, A.S.; KHEHRA, A.S. Direct and indirect effects of selection on maize performance and combining ability in maize. Maydica, Bergamo, 35: 2933, 1990.

REGAZZI, A.J·; SILVA, J.C.; THIÉBAUT, J.T.L.; OLIVEIRA, L.M.; GALVÃO, J.D. Variâncias covariâncias e correlações fenotípicas e genéticas aditivas em um composto de milho (Zea mays L.).Revista Ceres, Viçosa,27: 32-46, 1982.

REIS, F.P.; SILVA, J.C.; REGAZZI, A.J.; OLIVEIRA, L.M. Herdabilidades, correlações e índices de seleção em milho. Revista Ceres, Viçosa, 29: 168-83, 1982.

REMINSON, S.V. \& AKINLEYE, D. Relantionship between lodging, morphological characters and yield of varieties of maize. Journal of Agricultural Science, Cambridge, 91: 633-8,1978.

RISSI, R. Estimação de parâmetros genéticos em duas subpopulações de variedades de milho (Zea mays L.) Piranão. Piracicaba, 1980. 87 p. (Mestrado-Escola Superior de Agricultura " Luiz de Queiroz "/USP).

ROBINSON, H.F.; COMSTOCK, R.E.; HARVEY, P.H. Estimates of heritability and degree of dominance in corn. Agronomy Journal, Madison, 41: 353-9, 1949.

ROBINSON, H.F; COMSTOCK, R.E; HARVEY, P.H; Genetic variances in open pollinated varieties of corn. Genetics, Princeton, 40: 45-60, 1955.

RODGERS, J.S. \& EDWARDSON, J.R. The utilization of citoplasmic male-sterily inbreds in the production of corn hybrids. Agronomy Journal, New York, 57: 580-3, 1965.

RUSSELL, W.A. Genetic effects and genetic effect $X$ year interaction at three gene loci in sublines of maize inbred line. Canadian Journal of Genetics and Citology, Ottawa, 18: 23-33, 1976.

RUSSELL, W.A. \& EBERHART, S.A. Effects of three gene loci in the inheritance of quantitative characteres in maize. Crop Science, Madison, 10: 165-9, 1970. 
SAMPAIO, N.F. Propriedades genéticas e potencial para o melhoramento dos compostos de milho (Zea mays L.) ESALQ PB-4 e ESALQ PB-5. Piracicaba, 1986. 105 p.(Mestrado-Escola Superior de Agricultura " Luiz de Queiroz "/USP ).

SAN VICENTE, F.N. \& HALLAUER, A.R. Inbreeding depression rates of materials desirable from two groups of maize. Revista Brasileira de Genética, Ribeirão Preto, 16: 989-1001, 1993.

SANFORD, J.O.; GROGAN, C.O.; JORDAN, H.V.; SARVELLA, P.A. Influence of male-sterility on nitrogen utilization in corn (Zea mays L.). Agronomy Journal, New York, 57: 580-3, 1965.

SANTOS, M.X Estudo do potencial genético de duas raças brasileiras de milho (Zea mays L.) para fins de melhoramento. Piracicaba, 1985, 186 p. (Doutorado-Escola Superior de Agricultura " Luiz de Queiroz "/USP).

SAWAZAKI, E. Treze ciclos de seleção entre e dentro de familias de meios irmãos para produção de grãos no milho IAC Maya. Piracicaba, 1979, 99 p.(Mestrado-Escola Superior de Agricultura "Luiz de Queiroz"/USP).

SCHENELL, F.W. The covariance between relatives in the presence of linkage. In: HANSON, W.D.; ROBINSON, H.F. Statical Genetics and Plant Breeding. NAS-NRC, Publ. n 982. Washington, d.c., 1963.

SEGÓVIA, R.T. Seis ciclos de seleção entre e dentro de famílias de meios irmãos no milho (Zea mays L.) Centralmex. Piracicaba, 1976. (Doutorado-Escola Superior de Agricultura "Luiz de Queiroz "/USP).

SILVA, J. Seleção entre e dentro de familias de meios irmãos no milho Cateto Colombia Composto. Piracicaba, 1969. 74 p.(Mestrado-Escola Superior de Agricultura "Luiz de Queiroz"/USP).

SILVA, A.C. Comparação entre linhagens e hibridos de milho(Zea mays L.) de porte anão e suas versões braquiticas. Piracicaba, 1984. 100 p. (Doutorado-Escola Superior de Agricultura "Luiz de Queiroz "/USP ). 
SILVA, W.J. \& LONNQUIST, J.H. Genetic variance in populations developed from full-sib and $\mathrm{S} 1$ testcross progeny selections in a open-pollinated variety of maize. Crop Science, Madison, 8: 201-4, 1968.

SILVA, J.C. \& HALLAUER, A.R. Estimation of epistatic variance in lowa Stiff Stalk Synthetic maize. Journal of Heredity, Washington, 66: 290-6, 1975.

SILVEIRA, M.G.; SILVA, J.C.; REGAZZI, A.J.; GALVÃO, J.D. Avaliação da variabilidade genética de híbridos crípticos interpopulacionais de milho(Zea mays L.) em dois ciclos de seleção recorrente recíproca. Revista Ceres, Viçosa, 38: 217-28, 1991.

SOARES FILHO, W.S. Características fenotípicas e genéticas das populações de milho (Zea mays L.) braquítico Piranão - VD2B e Piranão VFIB. Piracicaba, 1987. 151 p. (Doutorado-Escola Superior de Agricultura "Luiz de Queiroz "/USP).

SOUZA Jr., C.L. Variabilidade genética em milho (Zea mays L.) e relações com a seleção intra e interpopulacional. Piracicaba, 1983. 151 p. (Doutorado-Escola Superior de Agricultura "Luiz de Queiroz "/USP).

SOUZA Jr., C.L. \& ZNSLY, J.R. Avaliação de variedades de milho (Zea mays L) braquítico-2 em cruzamentos dialélicos. Relatório Científico do Instituto de Genética, ESALQ/USP. Piracicaba, 15: 271-84, 1981.

SOUZA Jr., C.L. \& ZINSLY, J.R. Relative genetic potential of braquitic maize (Zea mays L.) varieties as breeding populations. Revista Brasileira de genética, Ribeirão Preto, 8: 523-33, 1985.

SOUZA Jr., C.L.; GERALDI, I.O.; ZINSLY, J.R. Influence of tassel size on the expression of prolificity in maize (Zea mays L.). Maydica, Bergamo, 30: 321-8, 1985.

STEBBINS, G.L. Self-fertilization and population variability in the higher plants. American Nature, Lancaster, 91: 337-54, 1957. 
STEBBINS, G.L. O isolamento reprodutivo e a origem das espécies. In ed---- Processos de evolução orgânica. São Paulo, EDUSP/ Polígono, 1970, cap. 5, p. 116-53.

STEEL, C.W. \& TORRIE, J.H. Principles and procedures of statistics. New York, Mc Grow Hill Book, 1960.

STROMBERG, L.D. \& COMPTON, R.J. Ten cycles of full-sib selection in maize. Crop Science, Madison, 29: 1179-72, 1989.

STUBER, C.W.; MOLL, R.H.; HANSON, W.D. Genetic variances and interrelationships of six traits in a hybrid population of maize (Zea mays $\mathrm{L}$.). Crop Science, Madison, 6: 455-8, 1966.

STUCKER, D.S.\& HALLAUER, A.R. Genetic variability as affected by selection in Iowa Stiff Stalk Syntetic maize. Journal of Heredity, Washignton, 83: 410-18, 1992.

SUBANDI, A. \& COMPTON, W.A. Genetic studies in a exotic population of corn(Zea mays L.) grown under two plant densities. Theorithical and Apllied Genetics, Berlin, 44: 153-159, 1974.

TEYKER, R.H.; MOLL, R.H.; JACKSON, W.A. Divergent selection among maize seedling for nitrate uptake. Crop Science, Madison, 29: 879-84, 1989.

THOMPSON, D.L. Recurrent selection for stalk lodging resistance and suceptibility in two populations of corn. Agronomy Abstracts, Madison, 62: p.21, 1970.

TORREGROZA, C.M. Ocho ciclos de secion massal divergent por marzocas por planta en una variedad sintetica de maiz. Revista Facultade Nacional de Agronomia, Medellin, 29: 3-25, 1974.

TORRES SEGÓVIA, R. Seis ciclos de seleção entre e dentro de familias de meios irmãos do milho (Zea mays L.) Centralmex. Piracicaba, 1976. 98 p. (DoutoradoEscola Superior de Agricultura "Luiz de Queiroz "/USP). 
TOSELLO, G.A. \& GERALDI, I.O. Estimativas de parâmetros genéticos e fenotípicos para caracteres da planta e da qualidade do grão na população de milho ESALQVD. Relatório Científico do Instituto de Genética, ESALQ/USP. Piracicaba, 14: 183-9, 1980.

VALOIS, A.C.C. Eficiência comparativa de quatro métodos de seleção em uma população melhorada de milho (Zea mays L.). Piracicaba, 1982, 119 p. (Doutorado-Escola Superior de Agricultura "Luiz de Queiroz "/USP).

VALOIS, A.C.C. \& MIRANDA FILHO, J.B. Comparação entre métodos de seleção em milho cv. Centralmex. Pesquisa Agropecuária Brasileira, Brasilia, 19: 479-88, 1984.

VELLO, N.A. Endogamia. Piracicaba, Instituto de genética, ESALQ/USP, 29 p. , 1984. (Publicação Didática).

VENCOVSKY, R. Genética Quantitativa. In: KERR, W.E., org. Melhoramento e Genética. Edições Melhoramentos. p. 17-38, 1969.

VENCOVSKY, R. Herança Quantitativa. In: PATERNIANI, E., coord. Melhoramento e Produção do Milho no Brasil. Ed. Marprint. p. 122-201., 1978.

VENCOVSKY, R. \& BARRIGA, P. Genética Biométrica no Fitomelhoramento. Soc. Bras. Genética, Ribeirão Preto, 1992, 265 p.

VENCOVSKY, R.; MIRANDA FILHO, J.B.\& SOUZA Jr, C.L. Quantitative genetics and corn breeding in Brazil. IN: INTERNATIONAL CONFERENCE ON QUANTITATIVE GENETICS, 2., Raleigh. Procedings. Sunderland, Sinauer, 1988

VERA, G.A. \& CRANE, P.L. Effects of selection for lower ear height in synthetic populations of maize. Crop Science, Madison, 10: 286-8, 1970.

WEBEL, O.D. \& LONNQUIST, J.H. An evaluation of modified ear-to-row selection in a popoulation of corn (Zea mays L.). Crop Science, Madison, 7: 651-5, 1976. 
WEIR, B.S. \& COCKERHAM, C.C. Two locus theory in quantitative genetics. Procedure of the 29th Hybrid Corn Industry Research Conference. Washington, 1965, 20: 31-45.

WITTNER, S.H. Maximun production capacity of food crops. Bioscience, Washington, 24: 216-24, 1974.

WRIGHT, S. System of Mating. Genetics, Princeton, 6:.111 -78., 1921.

YANG, Y.K. A study on the nature of genes controlling hybrid vigor, as it affects silking time and plant height in maize. Agronomy Journal, Madison, 41: 309-12, 1949.

ZIMBACK, L. Estimação de parâmetros genéticos e fenotípicos em uma variedade de milho dentado braquítico opaco (Zea mays L.). Piracicaba, 1985. 169 p. (Mestrado-Escola Superior de Agricultura "Luiz de Queiroz"/USP). 
TABELAS 
TABELA 07- Médias populacionais obtidas por local para os caracteres altura de espiga $(\mathrm{AE})$, altura e planta (AP), número de ramificações do pendão (NR), peso de espigas (PE), comprimento do pendão (CP) e peso do pendão (PP). $1992 / 93$.

\begin{tabular}{|c|c|c|c|c|c|c|}
\hline POPULAÇĀO & $\mathrm{AE}(\mathrm{cm})$ & $\mathrm{AP}(\mathrm{cm})$ & NR & PE (g|pl) & $C P(\mathrm{~cm})$ & PP (cm) \\
\hline$R+($ PIRACICABA $)$ & 107,87 & 197,00 & 35,15 & 147,76 & 42,03 & 4,29 \\
\hline R+(RIO VERDE) & 113,40 & 201,93 & 42,96 & - & - & - \\
\hline R-(PIRACICABA) & 87,72 & 187,58 & 7,39 & 139,91 & 41,81 & 3,81 \\
\hline R-(RIO VERDE) & 91,31 & 189,49 & 8,94 & - & - & - \\
\hline$E+($ PIRACICABA $)$ & 138,59 & 237,36 & 22,53 & 170,92 & - & - \\
\hline E+ (RIO VERDE) & 128,58 & 221,49 & 23,08 & - & - & - \\
\hline E-(PIRACICABA) & 64,14 & 165,20 & 14,25 & 130,01 & - & - \\
\hline E-(RIOVERDE) & 70,29 & 159,84 & 18,31 & - & - & - \\
\hline${ }^{R+} \mathbf{S}$ (PIRACICABA) & 97,79 & 165,65 & 32,15 & - & 40,54 & 4,21 \\
\hline $\mathrm{R}_{-\mathrm{S}}$ (PIRACICABA) & 76,42 & 159,58 & 6,30 & - & 38,17 & 3,72 \\
\hline TEST.(PIRACICABA) & 85,16 & 169,67 & 19,41 & 194,86 & 43,62 & 3,53 \\
\hline TEST.(RIO VERDE) & 88,45 & 184,79 & 15,73 & - & - & - \\
\hline
\end{tabular}


TABELA 08- Médias populacionais (M), obtidas no quinto ciclo (C5)* e sexto ciclo (C6) e diferença relativa (DR) entre as subpopulações divergentes para os caracteres altura de espiga (AE), altura de planta (AP), número de ramificações do pendão (NR), peso de espigas $(\mathrm{PE})^{* *}$, comprimento do pendão $(C P)^{* *}$ e peso do pendão (PP) ${ }^{* *} .1992 / 93$.

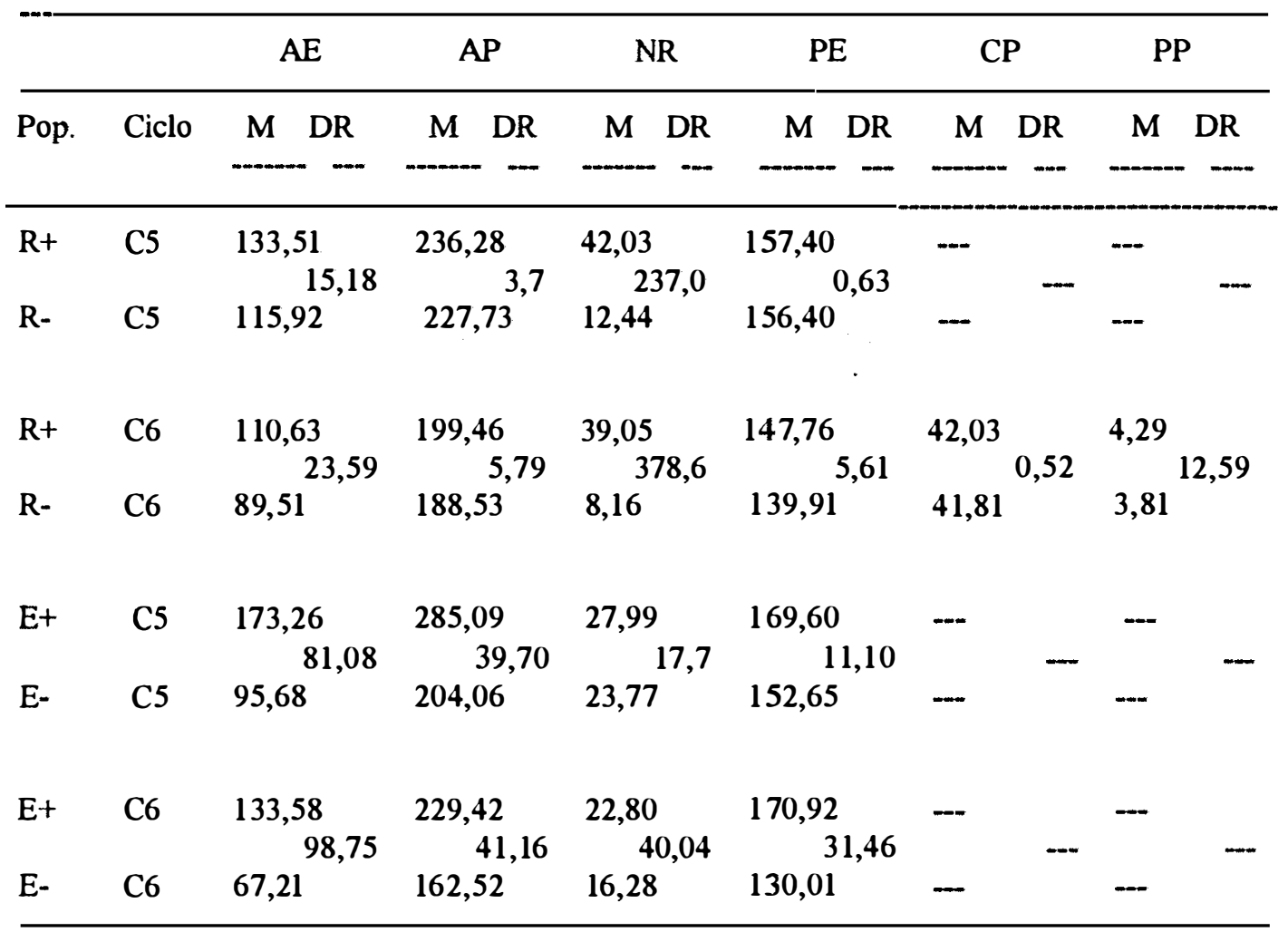

*-Dados obtidos por ARAÚJO (1992).

**-Dados do sexto ciclo obtidos apenas na localidade de Piracicaba.

TABELA 09- Estimativas de depressão por endogamia (\%) após uma geração de autofecundação para os caracteres altura de espigas (AE), altura de planta (AP), número de ramificações do pendão (NR), comprimento do pendão (CP) e peso do pendão (PP). Piracicaba-SP, 1992/93.

\begin{tabular}{llllll}
\hline POPULAÇÃO & AE & AP & NR & CP & PP \\
\hline R+s & 10,02 & 18,92 & 9,33 & 3,67 & 1,9 \\
R-S & 14,78 & 17,54 & 17,30 & 9,53 & 2,41 \\
\hline
\end{tabular}


TABELA 10- Quadrados médios e coeficiente de variação experimental (CVe) obtidos das análises agrupadas por local dos caracteres altura de espiga (AE), altura de planta (AP), número de ramificações do pendão (NR), peso de espigas (PE), comprimento do pendão (CP) e peso do pendão (PP). Piracicaba-SP, 1992/93.

\begin{tabular}{|c|c|c|c|c|c|c|c|c|}
\hline POPULAÇĀO & FV & GL & $\mathrm{AE}$ & AP & NR & $\mathrm{PE}$ & $\mathrm{CP}$ & PP \\
\hline & PROGÊNIES & 176 & $346,9685^{* *}$ & $528,4641^{* *}$ & $52,1993^{* *}$ & $516,3420^{* *}$ & $16,4146^{* *}$ & $0,1016^{* *}$ \\
\hline \multirow[t]{3}{*}{$\mathbf{R}^{+}$} & ERRO MÉDIO & 352 & 131,7794 & 134,4265 & 26,4703 & 316,4015 & 10,8897 & 0,0707 \\
\hline & $\mathrm{CVe}(\%)$ & - & 10,64 & 5,88 & 14,63 & 12,03 & 7,85 & 6,19 \\
\hline & PROGÊNIES & 165 & $323,6363^{* *}$ & $570,8834^{*}$ & $10,1430^{* *}$ & $450,9642^{*}$ & $22,6967^{* *}$ & $0,0170^{\text {ns }}$ \\
\hline \multirow[t]{2}{*}{$\mathrm{R}$ - } & ERRO MÉDIO & 330 & 134,5992 & 151,6541 & 4,1682 & 347,1374 & 7,7730 & 0,0131 \\
\hline & CVe (\%) & - & 13,22 & 6,56 & 27,61 & 13,31 & 6,66 & 3,00 \\
\hline \multirow{3}{*}{$\mathrm{E}+$} & PROGENIES & 162 & $718,4952^{* *}$ & $912,4314^{* *}$ & $44,6744^{* *}$ & $636,6351^{*}$ & - & - \\
\hline & ERRO MÉDIO & 324 & 371,8878 & 606,3489 & 20,5656 & 575,1251 & - & - \\
\hline & $\mathrm{CVe}(\%)$ & - & 13,91 & 10,37 & 20,12 & 14,03 & - & - \\
\hline \multirow{3}{*}{ E- } & PROGÊNIES & 214 & $303,5272^{* *}$ & $475,2869^{* *}$ & $36,7886^{* *}$ & $365,7263^{* *}$ & - & - \\
\hline & ERRO MÉDIO & 428 & 144,2286 & 225,1335 & 13,2736 & 274,4476 & - & - \\
\hline & CVe (\%) & - & 18,72 & 9,08 & 25,56 & 12,74 & - & - \\
\hline \multirow{3}{*}{$\mathrm{R}_{\mathrm{si}}$} & PROGENIES & 53 & $735,2899^{\mathrm{ns}}$ & $616,3897^{* *}$ & $95,2429^{* *}$ & - & $23,6115^{* *}$ & $0,1150^{* *}$ \\
\hline & ERRO MÉDIO & 106 & 631,1756 & 246,8320 & 30,8404 & - & 7,4752 & 0,0374 \\
\hline & $\mathrm{CVe}(\%)$ & - & 25,24 & 9,48 & 17,27 & - & 6,74 & 4,58 \\
\hline \multirow{3}{*}{$\mathrm{R}-\mathrm{s} \mathbf{1}$} & PROGÊNIES & 133 & $485,5436^{* *}$ & $904,2849^{* *}$ & $21,9977^{* *}$ & - & $33,2413^{* *}$ & $0,1701^{* *}$ \\
\hline & ERROMÉDIO & 266 & 174,9152 & 298,6606 & 6,7654 & - & 8,6796 & 0,0934 \\
\hline & CVe (\%) & - & 17,30 & 10,82 & 41,26 & - & 7,71 & 8,20 \\
\hline
\end{tabular}

** *-Significativo ao nivel de $1 \%$ e $5 \%$ de probabilidade, respectivamente. 
TABELA 11- Quadrados médios e e coeficiente de variação experimental (CVe), obtidos das análises agrupadas por local dos caracteres altura de espiga (AE), altura de planta (AP) e número de ramificações do pendão (NR). Rio Verde-GO, 1992/93.

\begin{tabular}{|c|c|c|c|c|c|}
\hline POPULAÇAOO & $\mathrm{VV}$ & GL & $\mathrm{Al}:$ & $\mathrm{AP}$ & NR \\
\hline \multirow{3}{*}{$\mathrm{R}+$} & PROGÊNIES & 176 & $389,1682^{* *}$ & $470,0632^{* *}$ & $114,0326^{* *}$ \\
\hline & ERRO MÉDIO & 352 & 81,1605 & 93,6636 & 32,2004 \\
\hline & $\mathrm{CVe}(\%)$ & - & 7,94 & . 4,79 & 13,20 \\
\hline \multirow{3}{*}{ R- } & PROGÊNIES & 165 & $274,0845^{* *}$ & $426,5992^{* *}$ & $15,1392^{* *}$ \\
\hline & ERRO MÉDIO & 330 & 72,5749 & 97,3957 & 3,4289 \\
\hline & CVe (\%) & - & 9,32 & 5,20 & 20,69 \\
\hline \multirow{3}{*}{$E+$} & PROGÊNIES & 162 & $393,3298^{* *}$ & $456,1542^{* *}$ & $35,0194^{* *}$ \\
\hline & ERROMÉDIO & 162 & 188,5351 & 240,2498 & 11,8449 \\
\hline & $\mathrm{CVe}(\%)$ & - & 10,67 & 6,79 & 14,96 \\
\hline \multirow{3}{*}{$\begin{array}{l}\mathrm{P} \\
\mathrm{E} \\
\mathrm{C}\end{array}$} & ROGÊNIES & 214 & $196,6318^{* *}$ & $254,6557^{* *}$ & $27,8235^{* *}$ \\
\hline & ERO MÉDIO & 214 & 51,5796 & 86,2664 & 8,5079 \\
\hline & CVe (\%) & - & 10,21 & 5,81 & 15,92 \\
\hline
\end{tabular}

** , * -Significativo aos niveis de $1 \%$ e $5 \%$ de probabidade, respectivamente. 
TABELA 12- Quadrados médios obtidos através da análise conjunta de experimentos, para os caracteres altura de espiga (AE), altura de planta (AP) e número de ramificações do pendão (NR), envolvendo as localidades de Piracicaba-SP e Rio Verde-GO. Subpopulação R+, 1992/93.

\begin{tabular}{|c|c|c|c|c|c|}
\hline EXPERIMENTO & FV & GL & $A E$ & AP & NR \\
\hline \multirow{4}{*}{ A } & PROGÊNIE & 49 & $397,1259^{* *}$ & $650,8550^{* *}$ & $94,1957^{* *}$ \\
\hline & LOCAL & 1 & $417,7200^{n s s}$ & $170,2533^{1 \mathrm{~ns}}$ & $3275,6892^{* *}$ \\
\hline & PROG X LOC & 49 & $210,4985^{11 s}$ & $247,3210^{* *}$ & $27,0596^{\mathrm{ns}}$ \\
\hline & ERRO MÉDIO & 196 & 99,7213 & 105,2177 & 25,568 \\
\hline \multirow{4}{*}{ B } & PROGÊNIE & 51 & $664,7588^{* *}$. & $785,9523^{* *}$ & $126,9368^{* *}$ \\
\hline & LOCAL & 1 & $237,6474^{\text {ns }}$ & $290,2091^{\text {ns }}$ & $5786,6670^{* *}$ \\
\hline & PROG X LOC & 51 & $103,1022^{\mathrm{ns}}$ & $185,1358^{* *}$ & $39,6488^{\text {ns }}$ \\
\hline & ERRO MÉDIO & 204 & 103,1837 & 110,0909 & 28,8710 \\
\hline \multirow{4}{*}{ c } & PROGÊNIE & 51 & $685,0672^{* *}$ & $1014,0347^{* *}$ & $151,6231^{* *}$ \\
\hline & LOCAL & 1 & $9679,2189^{* *}$ & $6501,0674^{* *}$ & $5352,9661^{* *}$ \\
\hline & PROG X LOC & 51 & $126,7878^{11 \mathrm{~s}}$ & $106,5678^{\mathrm{ns}}$ & $51,0196^{*}$ \\
\hline & ERRO MÉDIO & 196 & 107,4934 & 125,0505 & 32,1297 \\
\hline \multirow{4}{*}{ D } & PROGÊNIE & 28 & $669,9544^{* *}$ & $894,3736^{* *}$ & $127,5606^{* *}$ \\
\hline & LOCAL & 1 & $10869,6534^{* *}$ & $8353,7804^{* *}$ & $2423,1826^{* *}$ \\
\hline & P'ROG X LOC & 28 & $100,43945^{n S}$ & $116,9626^{\mathrm{nS}}$ & $51,4498^{*}$ \\
\hline & ERRO MÉDIO & 224 & 122,7099 & 117,1153 & 32,3927 \\
\hline
\end{tabular}

** , - Significativo aos niveis de $1 \%$ e $5 \%$ de probabilidade, respectivamente. 
TABELA 13- Quadrados médios obtidos através da análise conjunta de experimentos, para os caracteres altura de espiga (AE), altura de planta (AP) e número de ramificações do pendão (NR), envolvendo as localidades de Piracicaba-SP e Rio Verde-GO.Subpopulação R-, 1992/93.

\begin{tabular}{|c|c|c|c|c|c|}
\hline EXPERIMENTO & FV & GL & AE & $\mathbf{A P}$ & NR \\
\hline \multirow{4}{*}{ A } & PROGÊNIE & 56 & $418,3508^{* *}$ & $962,8144^{* *}$ & $25,4098^{* *}$ \\
\hline & LOCAL & 1 & $24,5695^{* *}$ & $17,6377^{* *}$ & $79,9272^{* *}$ \\
\hline & PROG X LOC & 56 & $86,9108^{n s}$ & $19,5650^{n s}$ & $3,7274^{\mathrm{ns}}$ \\
\hline & ERRO MÉDIO & 196 & 90,7560 & 117,7534 & 3,8330 \\
\hline \multirow{4}{*}{$\mathbf{B}$} & PROGÊNIE & 35 & $470,0821^{* *}$ & $850,0090^{* *}$ & $19,2601^{* *}$ \\
\hline & LOCAL & 1 & $2784,9214^{\mathrm{ns}}$ & $1310,8733^{* *}$ & $359,3936^{* *}$ \\
\hline & PROG X LOC & 55 & $157,6142^{*}$ & $13,4316^{\mathrm{ns}}$ & $3,5572^{\text {ns }}$ \\
\hline & ERRO MÉDIO & 220 & 108,1825 & 133,0510 & 3,8458 \\
\hline \multirow{4}{*}{ C } & PROGENIE & 54 & $552,9349^{* *}$ & $888,4457^{* *}$ & $19,9646^{* *}$ \\
\hline & LOCAL & 1 & $1721,2528^{* *}$ & $147,5567^{\mathrm{ns}}$ & $217,7229^{* *}$ \\
\hline & PROG X LOC & 54 & $110,1390^{\mathrm{ns}}$ & $144,2606^{n s}$ & $3,8920^{*}$ \\
\hline & ERRO MÉDIO & 216 & 112,2128 & 122,8634 & 3,7172 \\
\hline
\end{tabular}

** ,-Significativo a os niveis de $1 \%$ e $5 \%$ de probabilidade, respectivamente 
TABELA 14- Quadrados médios obtidos através da análise conjunta de experimentos, para os caracteres altura de espiga (AE), altura de planta (AP) e número de ramificações do pendão (NR), envolvendo as localidades de Piracicaba-SP e Rio Verde-GO. Subpopulação E+, 1992/93.

\begin{tabular}{|c|c|c|c|c|c|}
\hline EXP'LRIMENTO & IV & Ol. & $\mathrm{AE}$ & $\mathbf{A P}^{\mathbf{P}}$ & NR \\
\hline \multirow{4}{*}{ A } & PROGENIE & 54 & $751,4246^{* *}$ & $731,1127^{* *}$ & $35,8772^{* *}$ \\
\hline & LOCAL & 1 & $7271,5399^{\mathrm{ns}}$ & $431,9234^{\mathrm{ns}}$ & $5,6360^{n s}$ \\
\hline & PROC: X LOC & 54 & $348,9396^{\text {ns }}$ & $468,5256^{\mathrm{ns}}$ & $19,6315^{* *}$ \\
\hline & ERRO MÉDIO & 216 & 236,3865 & 410,4587 & 18,1376 \\
\hline \multirow{4}{*}{ B } & PROGENIE & 53 & $538,5817^{* *}$ & $762,3444^{* *}$ & $30,3895^{* *}$ \\
\hline & LOCAL & 1 & $45915,8797^{* *}$ & $71523,4578^{* *}$ & $7,2373^{n 18}$ \\
\hline & PROG $\times$ LOC & 53 & $348,9291^{n s}$ & $331,9983^{\mathrm{ns}}$ & $15,8144^{n \mathrm{~ns}}$ \\
\hline & ERRO MÉDIO & 220 & 326,7392 & 411,0800 & 17,4577 \\
\hline \multirow{4}{*}{ C } & PROGÊNIE & 55 & $804,5651^{* *}$ & $1236,0381^{* *}$ & $71,3994^{* *}$ \\
\hline & LOCAL & 1 & $13339,7357^{* *}$ & $11386,4886^{* *}$ & $337,0752^{* *}$ \\
\hline & PROG X LOC & 55 & $347,6378^{n 1 s}$ & $511,9590^{11 \mathrm{~s}}$ & $15,8227^{\mathrm{ns}}$ \\
\hline & ERRO MÉDIO & 220 & 368,4131 & 614,5823 & 17,3822 \\
\hline
\end{tabular}

** , *-Significativo aos niveis de $1 \%$ e $5 \%$ de probabilidade, respectivamente. 
TABELA 15- Quadrados médios obtidos da análise conjunta de experimentos para os caracteres altura de espiga (AE), altura de planta (AP) e número de ramificações do pendão (NR), envolvendo as localidades de Piracicaba-SP e Rio Verde-GO.Subpopulação E-, 1992/93.

\begin{tabular}{|c|c|c|c|c|c|}
\hline EXPERIMENTO & FV & GL & $\mathrm{AE}$ & $\mathbf{A P}$ & NR \\
\hline \multirow{4}{*}{ A } & PROGEENIE & 54 & $552,9349 * *$ & $349,9034^{* *}$ & $38,6561^{* *}$ \\
\hline & LOCAL & 1 & $1721,2528 * *$ & $360,8905^{n s}$ & $404,8688 * *$ \\
\hline & PROG X LOC & 54 & $110,1390^{\mathrm{ns}}$ & $135,4687^{\mathrm{ns}}$ & $11,5738^{* *}$ \\
\hline & ERRO MÉDIO & 216 & 112,2128 & 101,0990 & 6,5531 \\
\hline \multirow{4}{*}{$\mathbf{B}$} & PROGÊNIE & 55 & $486,3051^{* *}$ & $530,0747^{* *}$ & $63,6852^{* *}$ \\
\hline & LOCAL & 1 & $1194,4973 * *$ & $5588,4482^{*}$ & $536,6898^{* *}$ \\
\hline & PROG X LOC & 53 & $75,8901^{\mathrm{ns}}$ & $145,1270^{n s}$ & $16,23230^{\mathrm{ns}}$ \\
\hline & ERRO MÉDIO & 220 & 89,2497 & 124,3223 & 12,6778 \\
\hline \multirow{4}{*}{ C } & PROGÊNIE & 53 & $388,5902^{* *}$ & $732,5647^{* *}$ & $46,3461^{* *}$ \\
\hline & LOCAL & 1 & $7485,8702^{* *}$ & $4010,0280^{* *}$ & $1865,4534^{* *}$ \\
\hline & PROG X LOC & 53 & $150,3784^{\mathrm{ns}}$ & $194,6631^{\mathrm{ns}}$ & $12,7096^{\mathrm{ns}}$ \\
\hline & ERRO MÉDIO & 216 & 152,3642 & 291,5519 & 12,5871 \\
\hline \multirow{4}{*}{ D } & PROGÊNIE & 52 & $293,8863^{* *}$ & $538,3737^{* *}$ & $54,8862^{* *}$ \\
\hline & LOCAL & 1 & $2704,1135 * *$ & $2740,7518^{* *}$ & $2071,3830^{* *}$ \\
\hline & PROG X LOC & 52 & $165,7082^{\mathrm{ns}}$ & $211,2987^{\mathrm{ns}}$ & $15,6649^{\mathrm{ns}}$ \\
\hline & ERRO MÉDIO & 208 & 144,6470 & 202,2328 & 15,0452 \\
\hline
\end{tabular}

** , *-Significativo aos niveis de $1 \%$ e $5 \%$ de probabilidade, respecivamente. 
TABELA 16- Quadrados médios e coeficiente de variação experimental (CVe), obtidos das análises agrupadas conjuntas, para os caracteres altura de espiga (AE), altura de planta (AP) e número de ramificações do pendão (NR), $1992 / 93$.

\begin{tabular}{|c|c|c|c|c|c|}
\hline POPULAÇÃO & FV & GL & $\mathbf{A E}$ & AP & NR \\
\hline \multirow{5}{*}{$\mathbf{R +}$} & LOCAL & 1 & $1238,1972 * *$ & $8878,0827^{* *}$ & $16465,8231^{* *}$ \\
\hline & PROGENIES/EXP & 176 & $596,8141^{* *}$ & $828,8988^{* *}$ & $125,4303^{* *}$ \\
\hline & LOC*PROG/EXP & 176 & $139,3227^{*}$ & $169,6288^{*}$ & $40,8015^{* *}$ \\
\hline & ERRO MÉDIO & 704 & 106,4700 & 114,0451 & 29,3554 \\
\hline & $\mathrm{CVe}(\%)$ & - & 9,32 & 5,35 & 13,86 \\
\hline \multirow{5}{*}{ R- } & LOCAL & 1 & $3302,0707^{* *}$ & $922,8090^{* *}$ & $610,7072^{* *}$ \\
\hline & PROGENIES/EXP & 165 & $479,6403^{* *}$ & $900,8738 * *$ & $21,5067^{* *}$ \\
\hline & LOC*PROG/EXP & 165 & $118,0805^{n s}$ & $132,6092^{\mathrm{ns}}$ & $3,7061^{\mathrm{ns}}$ \\
\hline & ERRO MÉDIO & 660 & 103,5871 & 124,5250 & 3,7996 \\
\hline & $\mathrm{CVe}(\%)$ & - & 11,36 & 5,91 & 23,86 \\
\hline \multirow{5}{*}{$E+$} & LOCAL & 1 & $20124,4882 * *$ & $50292,4060^{* *}$ & $57,2828 * *$ \\
\hline & PROGENIES/EXP & 162 & $698,2977^{* *}$ & $923,5631^{\circ}$ & $60,8767^{* *}$ \\
\hline & LOC*PROG/EXP & 162 & $348,4943^{n s}$ & $484,3159^{\text {ns }}$ & $16,8896^{\mathrm{ns}}$ \\
\hline & ERRO MÉDIO & 486 & 310,7703 & 481,6049 & 17,6587 \\
\hline & $\mathrm{CVe}(\%)$ & - & 13,09 & 9,52 & 18,46 \\
\hline \multirow{5}{*}{ E- } & LOCAL & 1 & $9987,4042 * *$ & $7511,0045^{* *}$ & $4381,6540^{* *}$ \\
\hline & PROGENIES/EXP & 214 & $356,4679^{* *}$ & $559,1657^{* *}$ & $48,7728^{* *}$ \\
\hline & LOC*PROG/EXP & 214 & $122,3120^{\mathrm{ns}}$ & $170,7769^{n s}$ & $14,0464^{*}$ \\
\hline & ERRO MÉDIO & 642 & 113,3444 & 178,8445 & 11,6850 \\
\hline & $\mathrm{CVe}(\%)$ & - & 15,98 & 8,20 & 21,52 \\
\hline
\end{tabular}

** ,*- Significativo a o nivel de $1 \%$ e $5 \%$ de probabilidade, respectivamente. 
TABELA 17- Estimativas de variância fenotípica $\left(\sigma_{F}^{2}\right)$, variância genética entre progênies $\left(\sigma_{G}^{2}\right)$, e variância genética aditiva $\left(\sigma_{A}^{2}\right)$, para os caracteres altura de espiga (AE), altura de planta (AP), número de ramificações do pendão (NR), peso de espigas (PE), comprimento do pendão (CP) e peso do pendão (PP),obtidas ao nível de médias através das análises agrupadas por local . Piracicaba-SP,1992/93.

\begin{tabular}{|c|c|c|c|c|c|c|c|}
\hline POPULAÇÃO & & $\mathrm{AE}$ & AP & NR & $\mathrm{PE}$ & $\mathrm{CP}$ & $\mathbf{P P}$ \\
\hline & $\sigma_{F}^{2}$ & 115,6561 & 176,1547 & 17,3997 & 172,1140 & 5,4715 & 0,0338 \\
\hline \multirow[t]{3}{*}{$R+$} & $\sigma_{G}^{2}$ & 71,7297 & 131,3458 & 8,5763 & 66,5522 & 1,8416 & 0,0103 \\
\hline & $\sigma_{A}^{2}$ & 143,4594 & 262,6917 & $\begin{array}{l}17,1526 \\
\text {. }\end{array}$ & 88,7362 & 3,6326 & 0,0206 \\
\hline & $\sigma_{F}^{2}$ & 107,8787 & 190,2944 & 3,3810 & 150,3214 & 7,5655 & 0,0056 \\
\hline \multirow[t]{3}{*}{ R- } & $\sigma_{G}^{2}$ & 63,0123 & 139,7431 & 1,9916 & 34,6089 & 5,940 & 0,0013 \\
\hline & $\sigma_{A}^{2}$ & 126,0247 & 279,4862 & 3,9832 & 46,1455 & 11,8804 & 0,0026 \\
\hline & $\sigma_{F}^{2}$ & 239,4984 & 304,1447 & 14,8914 & 212,2117 & - & - \\
\hline \multirow[t]{3}{*}{$E+$} & $\sigma_{G}^{2}$ & 115,5358 & 102,0775 & 8,0377 & 20,50339 & - & - \\
\hline & $\sigma_{A}^{2}$ & 231,0716 & 216,1484 & 16,0745 & 27,33775 & - & - \\
\hline & $\sigma_{F}^{2}$ & 101,1757 & 158,4289 & 12,2628 & 121,9087 & - & - \\
\hline \multirow[t]{3}{*}{ E- } & $\sigma_{G}^{2}$ & 53,09950 & 83,3844 & 7,8383 & 30,4262 & - & - \\
\hline & $\sigma_{A}^{2}$ & 106,1990 & 166,7689 & 15,6766 & 40,5683 & - & - \\
\hline & $\sigma_{F}^{2}$ & 245,0966 & 205,4632 & 31,7476 & - & 7,87059 & 0,0383 \\
\hline \multirow[t]{3}{*}{$R+S$} & $\sigma_{G}^{2}$ & 34,7047 & 123,1859 & 21,4675 & - & 5,3787 & 0,0258 \\
\hline & $\sigma_{A}^{2}$ & 34,7047 & 123,1859 & 21,4675 & - & 5,3787 & 0,0258 \\
\hline & $\sigma_{F}^{2}$ & 161,8478 & 301,4283 & 7,3325 & - & 11,0804 & 0,0567 \\
\hline \multirow[t]{2}{*}{$R-S$} & $\sigma_{G}^{2}$ & 103,5438 & 201,8747 & 5,0771 & - & 8,1872 & 0,0255 \\
\hline & $\sigma_{A}^{2}$ & 103,5438 & 201,8747 & 5,0771 & - & 8,1872 & 0,0255 \\
\hline
\end{tabular}


TABELA 18- Estimativas de variâncias fenotípicas $\left(\sigma_{F}^{2}\right)$, variâncias genéticas entre progênies $\left(\sigma_{G}^{2}\right)$, e variâncias genéticas aditivas $\left(\sigma_{A}^{2}\right)$, para os caracteres altura de espiga (AE), altura de planta (AP) e número de ramificações do pendão (NR), obtidas ao nível de médias, através das análises agrupadas por local. Rio Verde-GO,1992/93.

\begin{tabular}{|c|c|c|c|c|}
\hline POPULAÇĀO & & $\mathrm{AE}$ & $A P$ & NR \\
\hline & $\sigma_{k}^{2}$ & 129,7227 & 156,6877 & 38,0108 \\
\hline \multirow[t]{3}{*}{$\mathbf{R +}$} & $\sigma_{G}^{2}$ & 102,6692 & 125,4665 & 27,2774 \\
\hline & $\sigma_{A}^{2}$ & 205,3384 & 250,9330 & 54,5548 \\
\hline & $\sigma_{F}^{2}$ & 91,36157 & $\cdot$ · 142,1997 & 5,0464 \\
\hline \multirow[t]{3}{*}{ R. } & $\sigma_{G}^{2}$ & 67,1698 & 121,7346 & 3,9034 \\
\hline & $\sigma_{A}^{2}$ & 134,3397 & 243,4692 & 7,8068 \\
\hline & $\sigma_{F}^{2}$ & 196,6649 & 228,0771 & 17,5097 \\
\hline \multirow[t]{3}{*}{ E+ } & $\sigma_{G}^{2}$ & 102,3973 & 107,9521 & 11,5872 \\
\hline & $\sigma_{A}^{2}$ & 204,7947 & 215,9043 & 23,174 \\
\hline & $\sigma_{F}^{2}$ & 98,3159 & 127,3278 & 13,9117 \\
\hline \multirow[t]{2}{*}{ E- } & $\sigma_{G}^{2}$ & 72,5270 & 84,1966 & 9,6577 \\
\hline & $\sigma_{A}^{2}$ & 145,0521 & 168,3933 & 19,3155 \\
\hline
\end{tabular}


TABELA 19-Estimativas de herdabilidades $\left(\mathrm{h}^{2} \mathrm{~m}\right)$ ao nivel de médias, obtidas através das análises agrupadas por populações e por local (superior Piracicaba; inferior Rio Verde) para os caracteres altura de espiga (AE), altura de planta (AP), número de ramificações do pendão (NR), peso de espigas (PE), comprimento do pendão (CP) e peso do pendão (PP),1992/93.

\begin{tabular}{lcccccc} 
& AE & AP & NR & PE & CP & PP \\
\hline R+ & 0,6201 & 0,7456 & 0,4928 & 0,3866 & 0,3365 & 0,3047 \\
& 0,7914 & 0,8007 & 0,7157 & -- & - & -- \\
R- & 0,5841 & 0,7343 & 0,5488 & 0,2302 & 0,7851 & 0,2294 \\
& 0,7352 & 0,8560 & 0,7735 & -- & -- & -- \\
& 0,4824 & 0,3356 & 0,5397 & 0,0966 & -- & -- \\
E+ & 0,5206 & 0,4733 & 0,6617 & -- & -- & -- \\
& 0,5248 & 0,5263 & 0,6391 & 0,2495 & -- & -- \\
E- & 0,7370 & 0,6609 & 0,6942 & & -- & - \\
& & & & & & \\
R+S & 0,5290 & 0,6761 & 0,6761 & -- & 0,6834 & 0,6736 \\
R-S & 0,6397 & 0,6905 & 0,6924 & -- & 0,7382 & 0,6684 \\
\hline MÉDIA & 0,5730 & 0,6499 & 0,6434 & 0,2407 & 0,6365 & 0,4690
\end{tabular}


TABELA 20- Estimativas do coeficiente de variação genético ( $\mathrm{CVg} \%)$ e do índice de variação (b), obtidas por população e por local para os caracteres altura de espiga (AE), altura de planta (AP), número de ramificações do pendão (NR), peso de espigas (PE), comprimento do pendão (CP) e peso do pendão (PP),1992/93.

PIRACICABA

\begin{tabular}{|c|c|c|c|c|c|c|c|c|c|c|c|c|}
\hline \multirow[b]{2}{*}{ POP. } & \multicolumn{2}{|c|}{$\mathrm{AE}$} & \multicolumn{2}{|c|}{$\mathrm{AP}$} & \multicolumn{2}{|c|}{ NR } & \multicolumn{2}{|c|}{ PE } & \multicolumn{2}{|c|}{$\mathrm{CP}$} & \multicolumn{2}{|c|}{ PP } \\
\hline & $\mathrm{CVg}$ & b & $\mathrm{CVg}$ & b & $\mathrm{CVg}$ & b & $\mathrm{CVg}$ & b & $\mathrm{CVg}$ & b & $\mathrm{CVg}$ & b \\
\hline $\mathrm{R}+$ & 7,85 & 0,73 & 5,80 & 0,98 & 8,33 & 0,57 & 5,52 & 0,45 & 3,22 & 0,41 & 2,36 & 0,38 \\
\hline $\mathrm{R}-$ & 9,04 & 0,68 & 6,30 & 0,96 & 19,10 & 0,69 & 4,20 & 0,31 & 5,82 & 0,87 & 0,94 & 0,31 \\
\hline $\mathrm{E}+$ & 7,75 & 0,55 & 4,25 & 0,40 & 12,58 & 0,62 & 2,64 & 0,18 & - & - & - & - \\
\hline E- & 11,36 & 0,60 & 5,52 & 0,61 & 19,64 & 0,76 & 4,24 & 0,33 & - & - & - & - \\
\hline $\mathrm{R}+\mathrm{S}$ & 8,21 & 0,61 & 6,70 & 0,70 & 14,44 & 0,83 & - & - & 5,71 & 0,84 & 3,82 & 0,83 \\
\hline $\mathrm{R}-\mathrm{S}$ & 13,31 & 0,76 & 8,90 & 0,82 & 35,76 & 0,86 & - & - & 6,55 & 0,85 & 4,29 & 0,52 \\
\hline
\end{tabular}

RIO VERDE

\begin{tabular}{|c|c|c|c|c|c|c|}
\hline \multirow[b]{2}{*}{ POPULAÇÃO } & \multicolumn{2}{|c|}{$\mathrm{AE}$} & \multicolumn{2}{|c|}{ AP } & \multicolumn{2}{|c|}{ NR } \\
\hline & $\mathrm{CVg}$ & b & $\mathrm{CVg}$ & b & $\mathrm{CVg}$ & b \\
\hline $\mathrm{R}+$ & 7,34 & 0,92 & 5,54 & 1,15 & 14,85 & 1,12 \\
\hline $\mathrm{R}-$ & 8,97 & 0,96 & 5,82 & 1,11 & 22,09 & 1,06 \\
\hline$E+$ & 7,86 & 0,73 & 4,37 & 0,62 & 14,74 & 0,98 \\
\hline E- & 12,11 & 1,18 & 5,55 & 0,56 & 16,97 & 1,06 \\
\hline
\end{tabular}


TABELA 21-Estimativas do coeficiente de variação genético (CVg\%) e do índice de variação (b), obtidas pela média dos dois locais para os caracteres altura de espiga (AE), altura de planta (AP), número de ramificações do pendão (NR) e peso de espigas (PE),1992/1993.

\begin{tabular}{|c|c|c|c|c|c|c|c|c|}
\hline \multirow[b]{2}{*}{ POP. } & \multicolumn{2}{|c|}{$\mathrm{AE}$} & \multicolumn{2}{|c|}{ AP } & \multicolumn{2}{|c|}{ NR } & \multicolumn{2}{|c|}{$\mathrm{PE}^{*}$} \\
\hline & $\mathrm{CVg}$ & b & $\mathrm{CVg}$ & b & $\mathrm{CVg}$ & b & $\mathrm{CVg}$ & b \\
\hline $\mathrm{R}+$ & 7,59 & 0,82 & 5,67 & 1,06 & 11,59 & 0,84 & 5,52 & 0,45 \\
\hline $\mathrm{R}$ - & 9,00 & 0,82 & 6,06 & 1,03 & 20,59 & 0,87 & 4,20 & 0,31 \\
\hline$P 0^{* *}$ & 8,31 & 1,06 & 5,19 & 1,02 & 12,49 & 0,92 & 10,01 & 0,84 \\
\hline $\mathrm{E}+$ & 7,80 & 0,64 & 4,31 & 0,51 & 13,66 & 0,90 & 2,64 & 0,18 \\
\hline E- & 11,73 & 0,79 & 5,64 & 0,58 & 18,30 & 0,91 & 4,24 & 0,33 \\
\hline
\end{tabular}

* Estimativas calculadas através de dados obtidos apenas em Piracicaba

** Estimativas calculadas através de dados obtidos por ANDRADE (1992) 
TABELA 22- Estimativas dos coeficientes de correlações genéticas $\left(r_{g}\right)$ e fenotípicas $\left(r_{f}\right)$ obtidas por população e por local, 1992/93.

\section{Piracicaba}

\begin{tabular}{|c|c|c|c|c|c|c|c|c|c|c|c|c|}
\hline & \multicolumn{2}{|c|}{$\mathbf{R}^{+}$} & \multicolumn{2}{|c|}{ R- } & \multicolumn{2}{|c|}{$\mathrm{E}+$} & \multicolumn{2}{|c|}{ E- } & \multicolumn{2}{|c|}{${ }^{R+s}$} & \multicolumn{2}{|c|}{$R_{-s}$} \\
\hline . & $\mathbf{r}_{\mathbf{q}}$ & $\mathbf{r}_{\mathbf{f}}$ & $\mathbf{r}_{\mathbf{q}}$ & $\mathbf{r}_{\mathbf{f}}$ & $\mathbf{r}_{\mathbf{q}}$ & $\mathbf{r}_{\mathbf{f}}$ & $\mathbf{r}_{\mathbf{g}}$ & $\mathbf{r}_{\mathbf{f}}$ & $\mathbf{r}_{\mathbf{g}}$ & $\mathbf{r}_{\mathbf{f}}$ & $\mathbf{r}_{\mathbf{g}}$ & $\mathbf{r}_{\mathbf{f}}$ \\
\hline $\mathrm{AE} \times \mathrm{AP}$ & 0,7926 & 0,7833 & 0,8091 & 0,7809 & 0,8384 & 0,8218 & 0.7396 & 0,7168 & 0,7894 & 0,7752 & 0,8702 & 0,8199 \\
\hline AE X NR & 0,1924 & 0,2051 & 0,0372 & 0,1576 & 0,1670 & 0,3697 & 0,2409 & 0,2847 & 0,6680 & 0,2095 & 0,3465 & 0,3260 \\
\hline $\mathrm{AE} \times \mathrm{PE}$ & 0,2933 & 0,0332 & 0,1763 & 0,1989 & 0,3882 & 0,3460 & 0,5034 & 0,3883 & - & - & - & - \\
\hline $\mathrm{AE} \times \mathrm{CP}$ & 0,4209 & 0,0821 & - & - & - & - & - & - & - & - & 0,4389 & 0,2808 \\
\hline AP X NR & 0,1345 & 0,1840 & 0,0199 & 0,0529 & 0,0412 & 0,2340 & 0,0880 & 0,2141 & 0,0920 & 0,1012 & 0,1602 & 0,2176 \\
\hline $\mathrm{AP} \times \mathrm{PE}$ & 0,1954 & 0,1742 & 0,0874 & 0,1224 & 0,2310 & 0,3607 & 0,3418 & 0,3145 & - & - & - & - \\
\hline $\mathrm{AP} \times \mathrm{CP}$ & 0,4385 & 0,2525 & - & - & - & - & - & - & 0,1274 & 0,0045 & 0,5805 & 0,4547 \\
\hline NR X PE & $-0,0218$ & 0,0095 & 0,4561 & 0,1179 & 0,2078 & 0,2231 & 0,1373 & 0,2868 & - & - & - & - \\
\hline $\mathrm{NR} \times \mathrm{CP}$ & $-0,0151$ & $-0,0095$ & 0,2321 & 0,0340 & - & - & - & - & - & - & $-0,0140$ & 0,0705 \\
\hline PE X CP & 0,0266 & 0,0076 & - & - & - & - & - & - & - & - & - & - \\
\hline
\end{tabular}

\begin{tabular}{|c|c|c|c|c|c|c|c|c|}
\hline & \multicolumn{8}{|c|}{ Rio Verde } \\
\hline & \multicolumn{2}{|c|}{$\mathbf{R}^{+}$} & \multicolumn{2}{|c|}{$\mathrm{R}$ - } & \multicolumn{2}{|c|}{$E+$} & \multicolumn{2}{|c|}{ E- } \\
\hline & $\mathbf{r}_{\mathbf{q}}$ & $\mathbf{r}_{\mathbf{f}}$ & $\mathbf{r}_{\mathbf{q}}$ & $\mathbf{r}_{\mathbf{f}}$ & $\mathbf{r}_{\mathbf{q}}$ & $\mathbf{r}_{\mathbf{f}}$ & $\mathbf{r}_{\mathbf{q}}$ & $\mathbf{r}_{\mathbf{f}}$ \\
\hline $\mathrm{AE} \times \mathrm{AP}$ & 0,8425 & 0,8118 & 0,7636 & 0,9114 & 0,8046 & 0,6746 & 0,7553 & 0,7035 \\
\hline AE X NR & 0,0648 & 0,1171 & 0,3006 & 0,2722 & 0,1505 & 0,3089 & 0,1319 & 0,1566 \\
\hline AP X NR & 0,1266 & 0,0408 & 0,0766 & 0,0846 & 0,0412 & 0,2340 & 0,0402 & 0,1021 \\
\hline
\end{tabular}


FIGURAS 

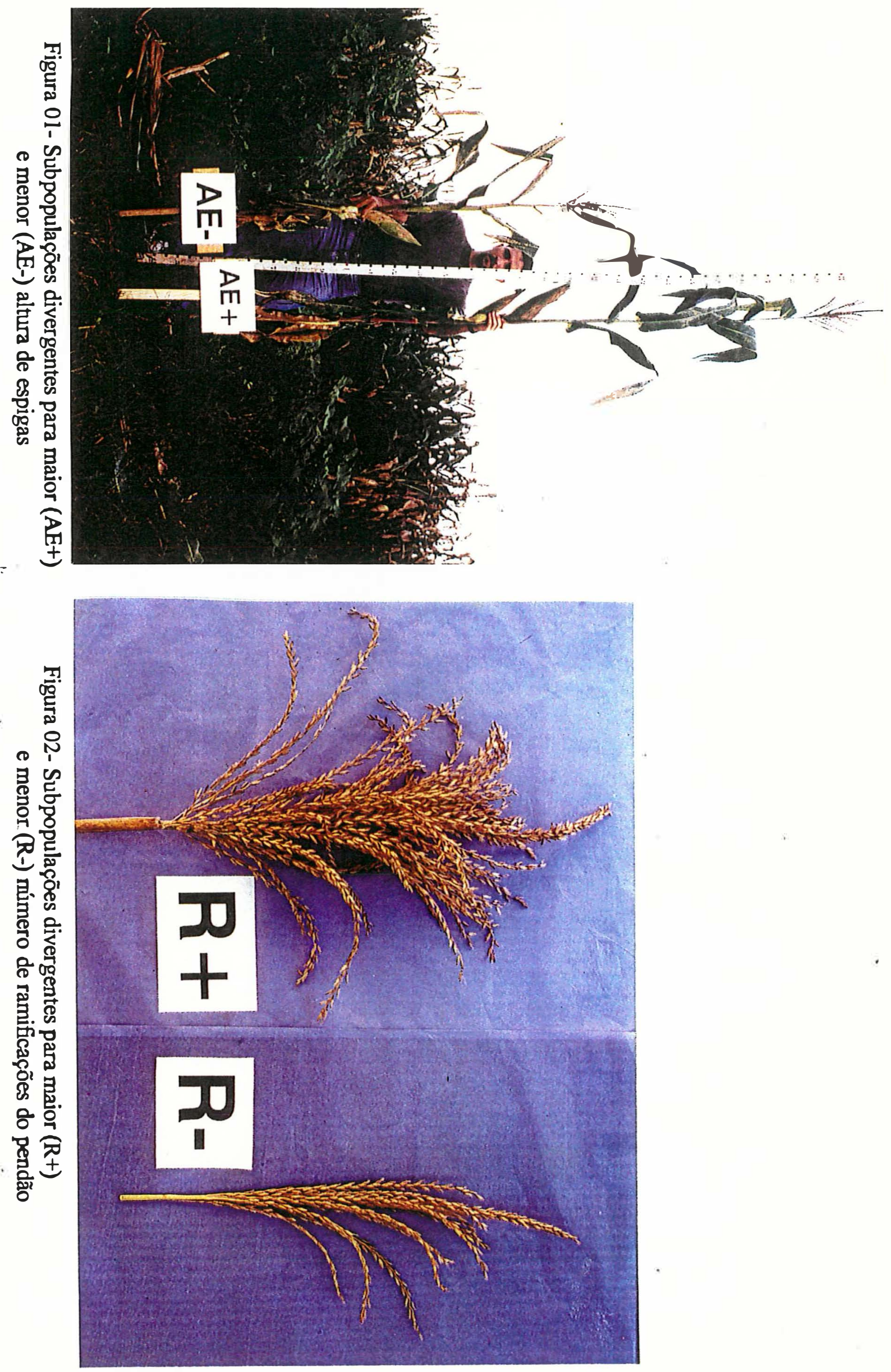

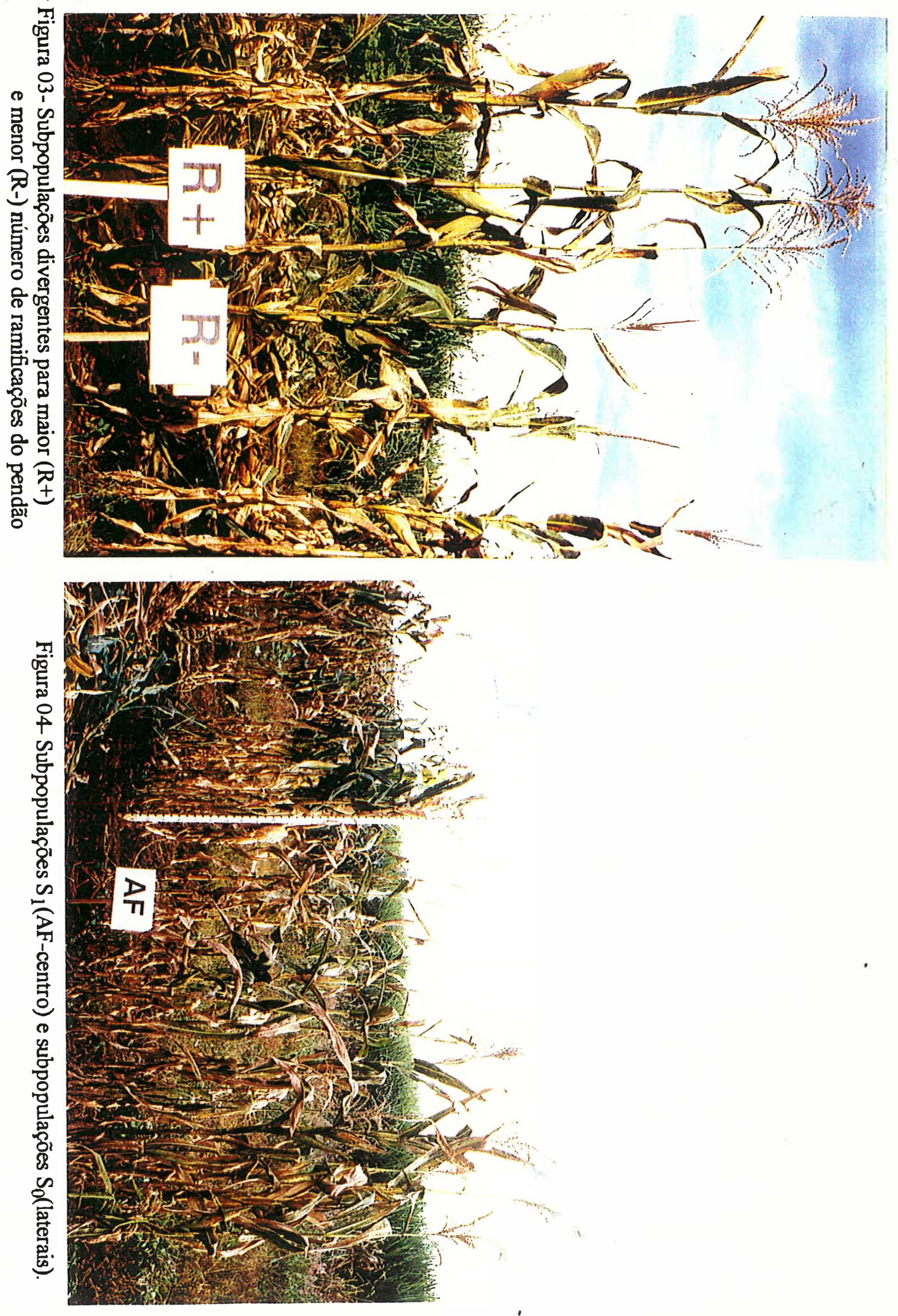
Piracicaba

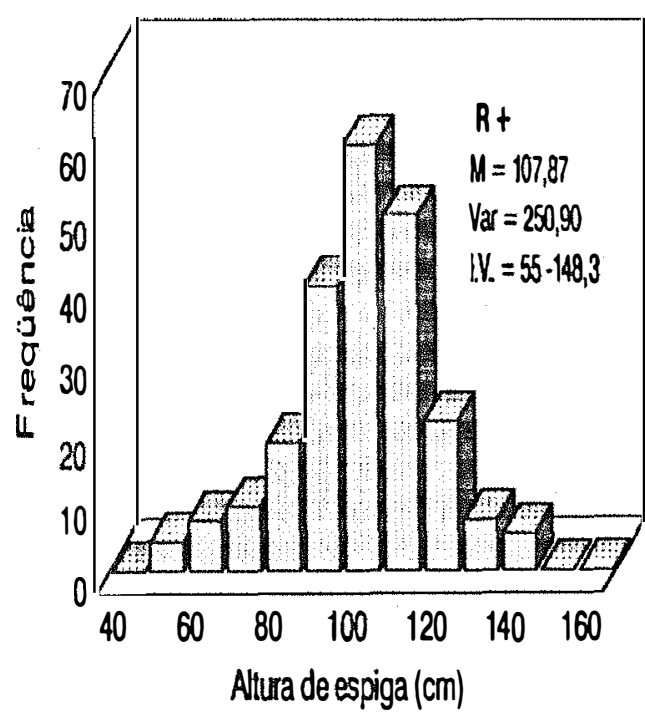

Piracicaba

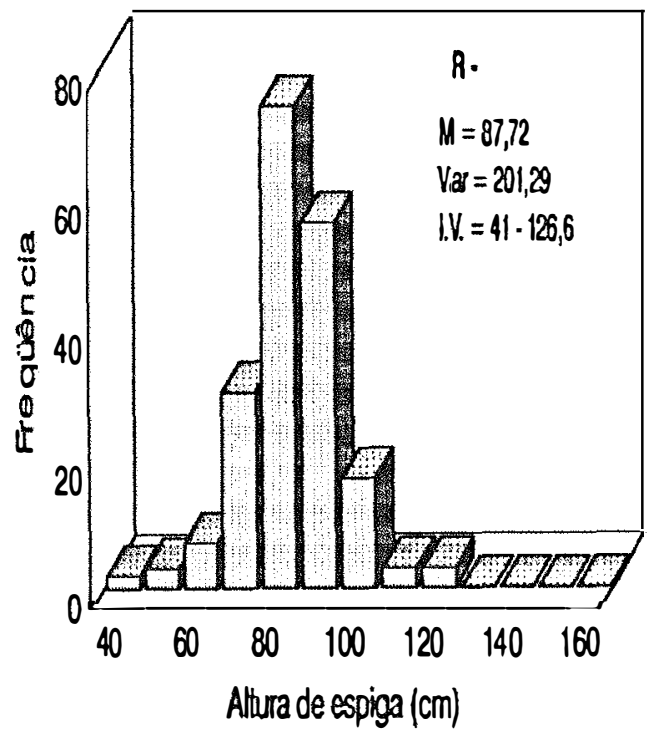

Rio Verde

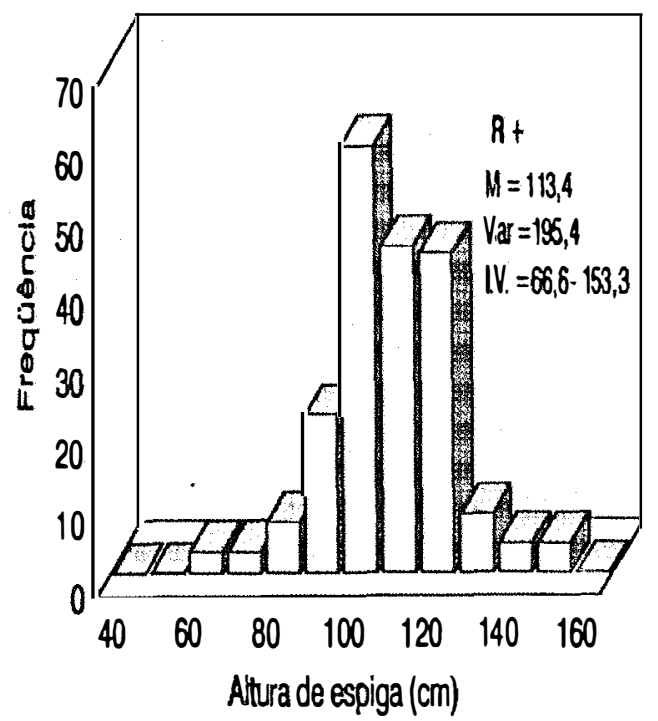

Rio Verde

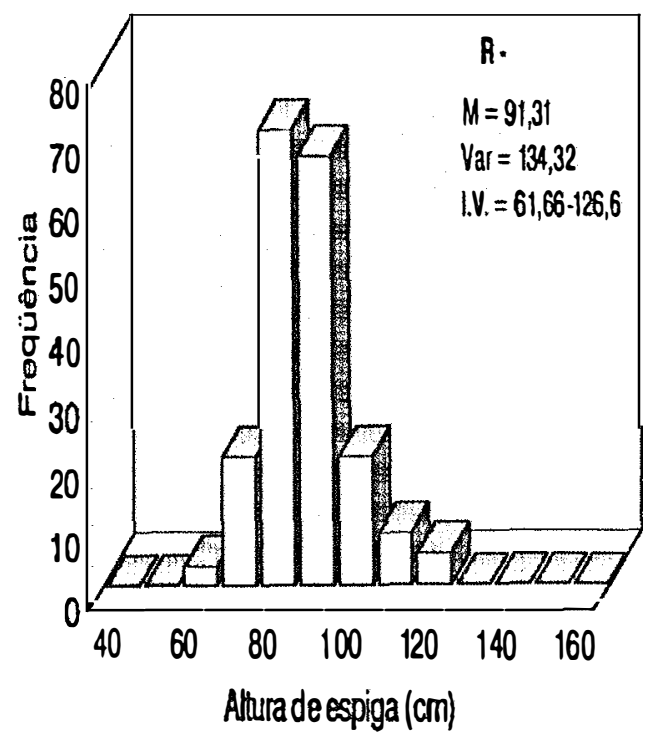

Figura 05 - Distribuiçāo de frequência de médias e valores de média populacional (M), veriância (Var) e intervalo de variação (I.V), para o caráter AE nas subpopulaçöes divergentes para NR. 


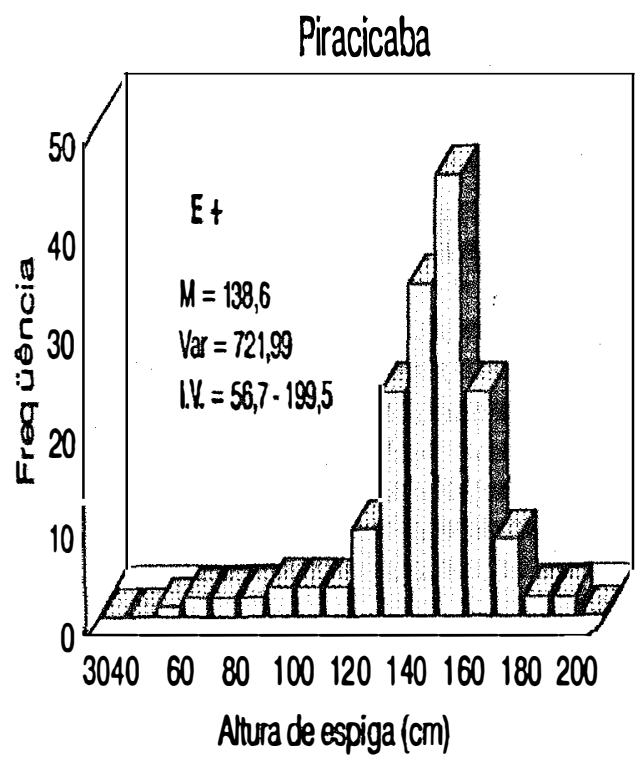

Pracicaba

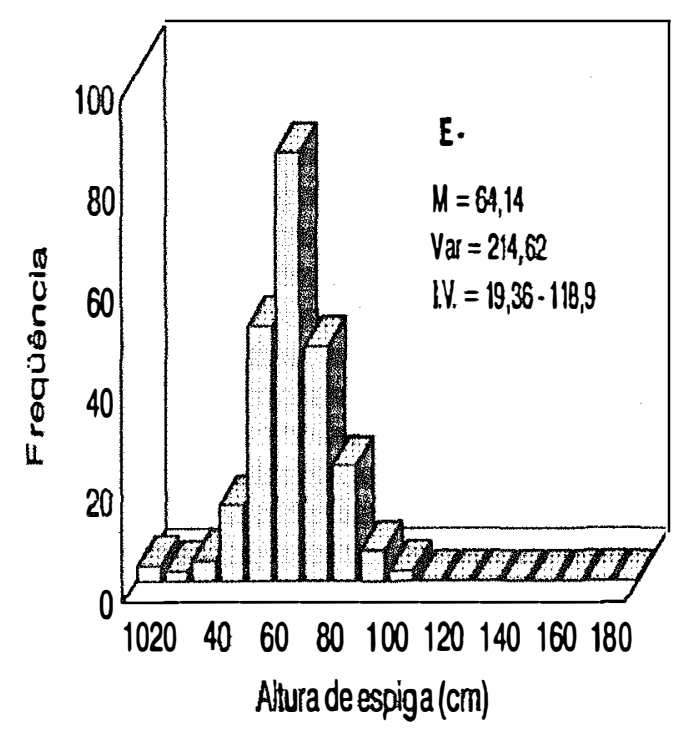

Rio Verde

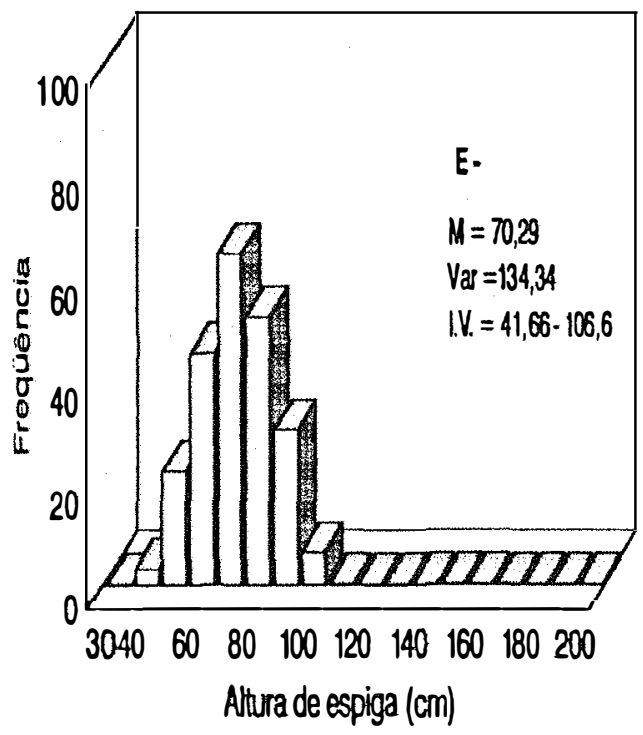

Figura 06 - Distribuiçäo de freqüência de médias e valores de média populacional ( $M$ ), variância (Var) e intervalo de variaçäo (I.V), para o caráter AE nas subpopulaçöes divergentes para AE. 

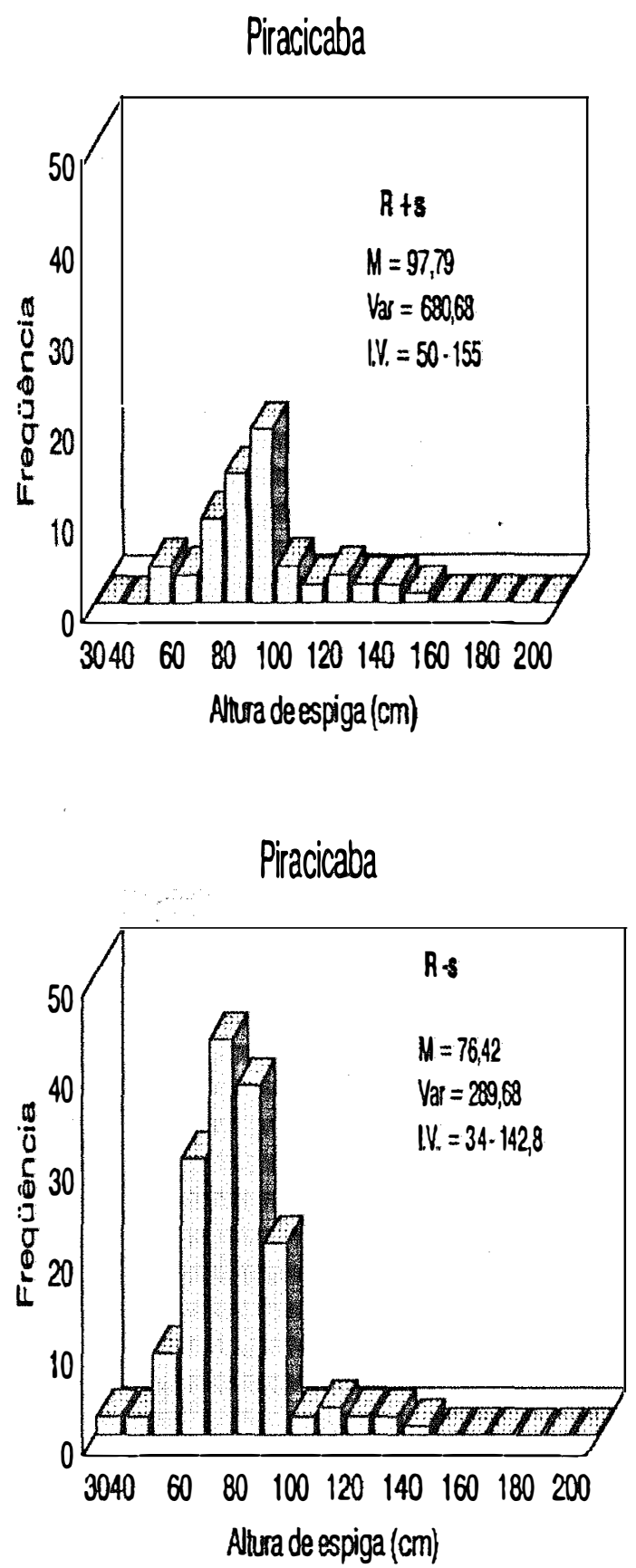

Figura 07 - Distribuiçäo de treqüência de médias e valores de média populacional (M), variância (Var) e intervalo de variação (IV), para o caráter AE nas subpopulaçöes S1 divergentes para NR. 

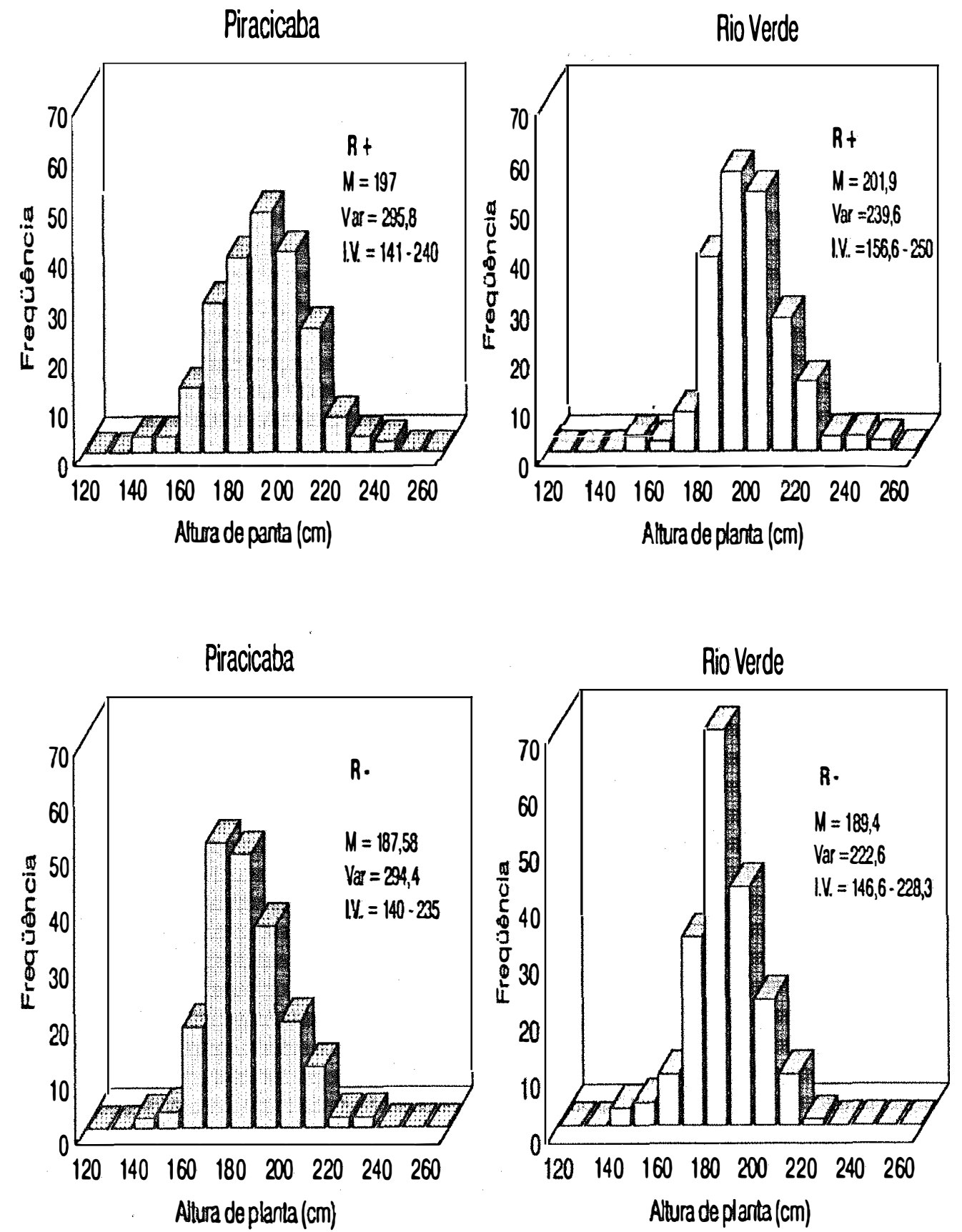

Figura 08 - Distribuiçäo de frequência de médias e valores de média populacional (M), variância ( Var) e intervalo de variaçāo (IV), para o caráter AP nas subpopulaçöes divergentes para NR. 


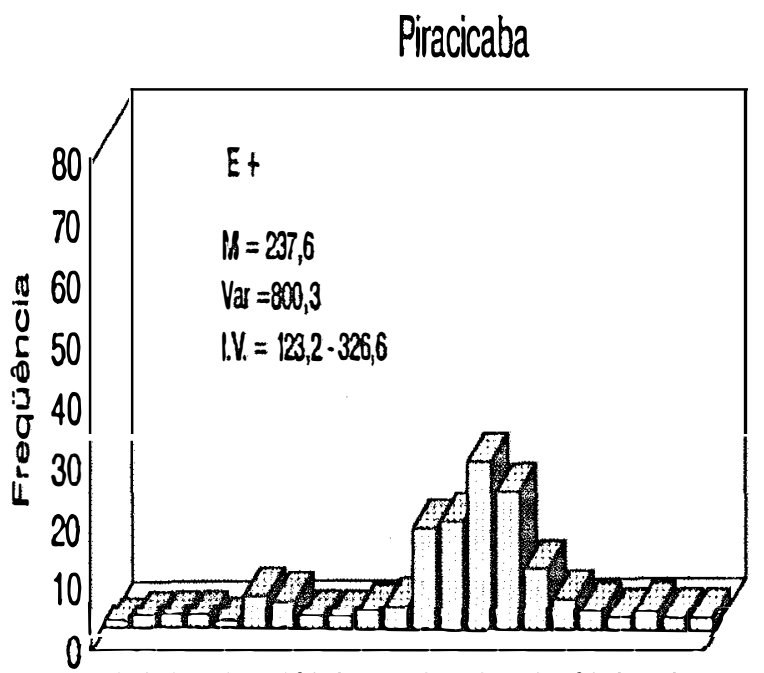

120140160180200220240260280300320

Altura de planta(cm)

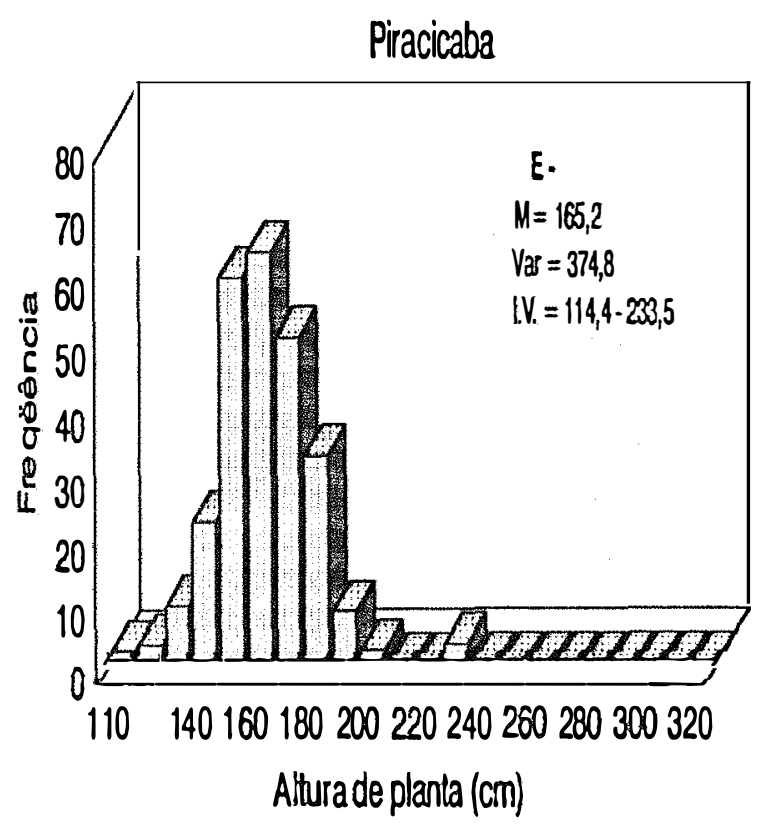

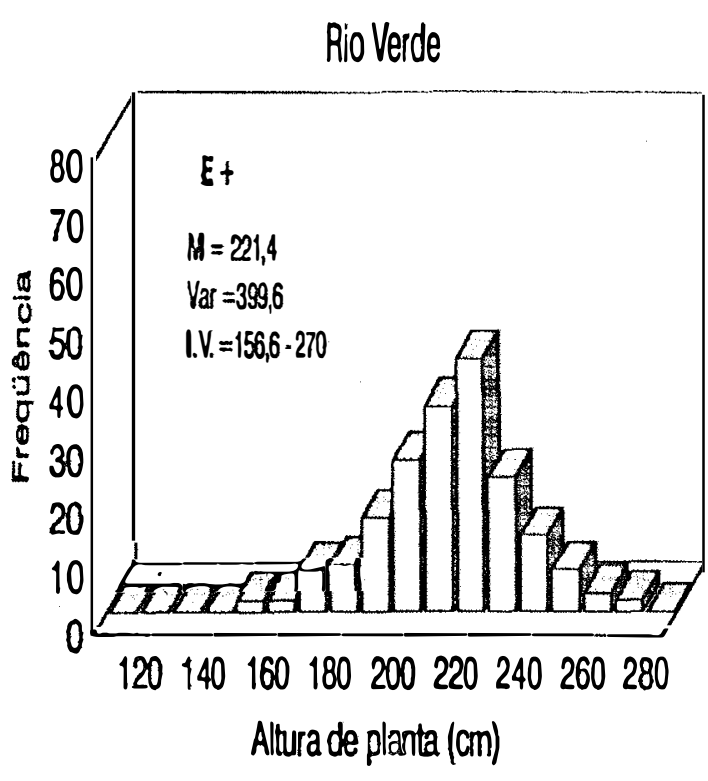

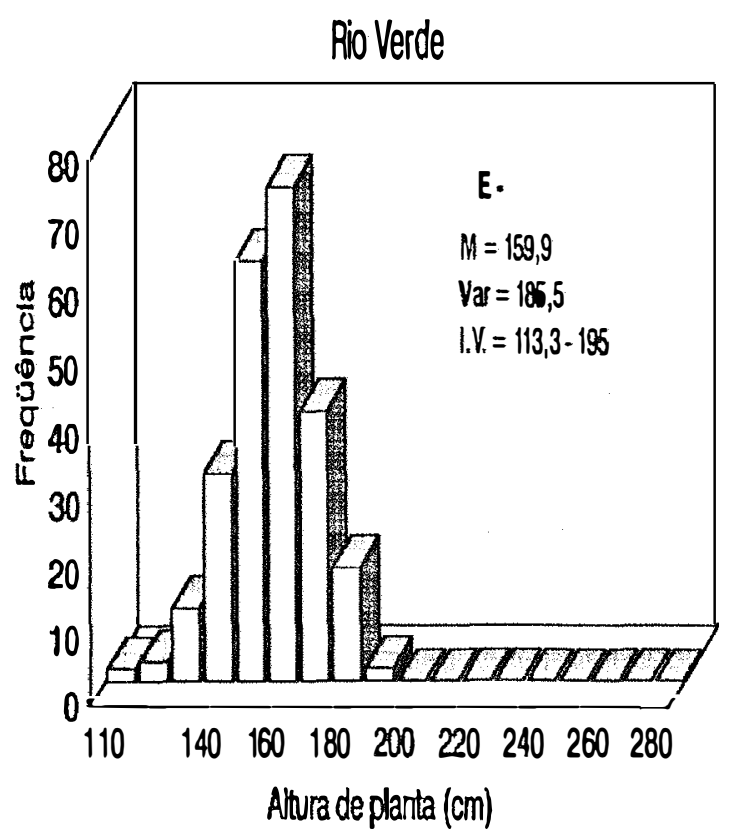

Figura 09-Distribuiçăo de frequêencia de médias e valores de média populacional ( $M$ ), variância (Var) e intevalo de variaçäo (I.V), para o caráter AP nas subpopulaçöes divergentes para AE. 

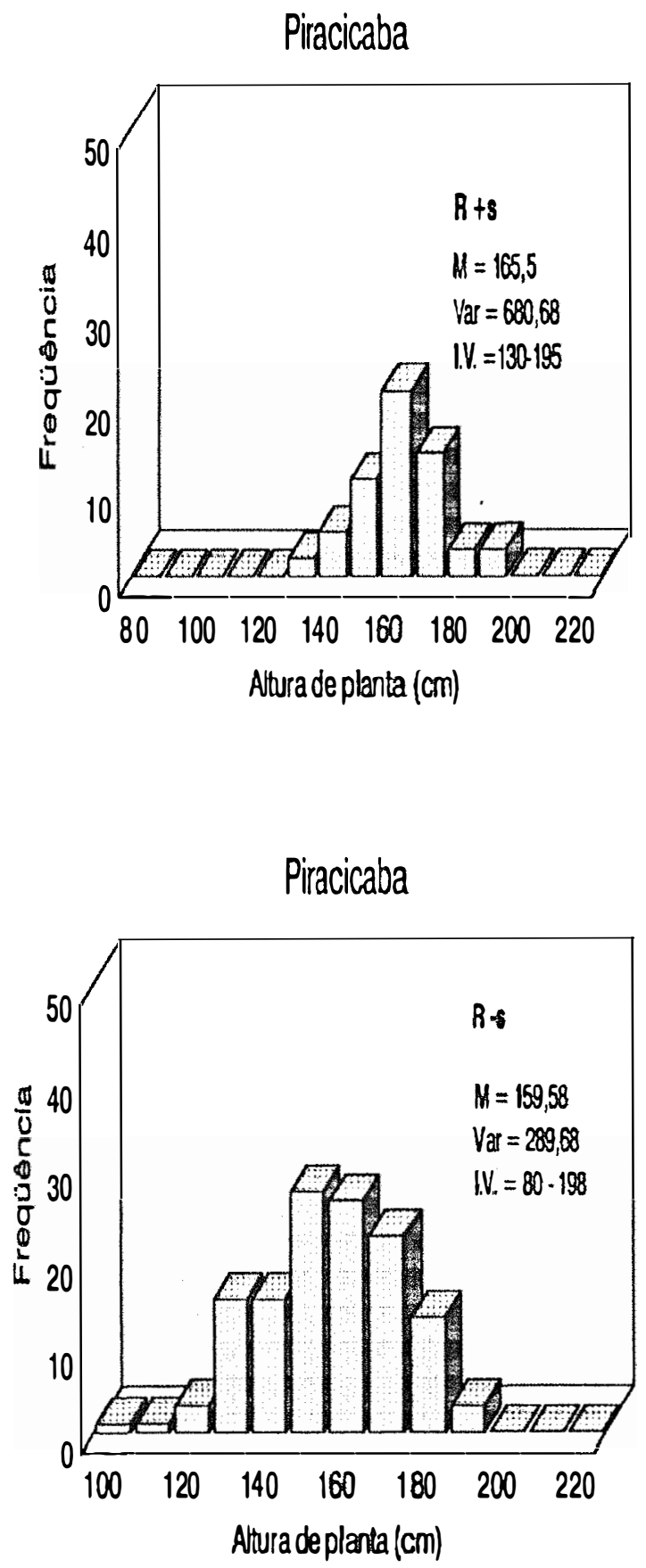

Figura 10 - Distribuição de frequêencia de médias e valores de média populacional ( $M$ ), variância (Var) e intervalo de variação (IV), para o caráter AP nas subpopulaçōes $S 1$ divergentes para NR. 

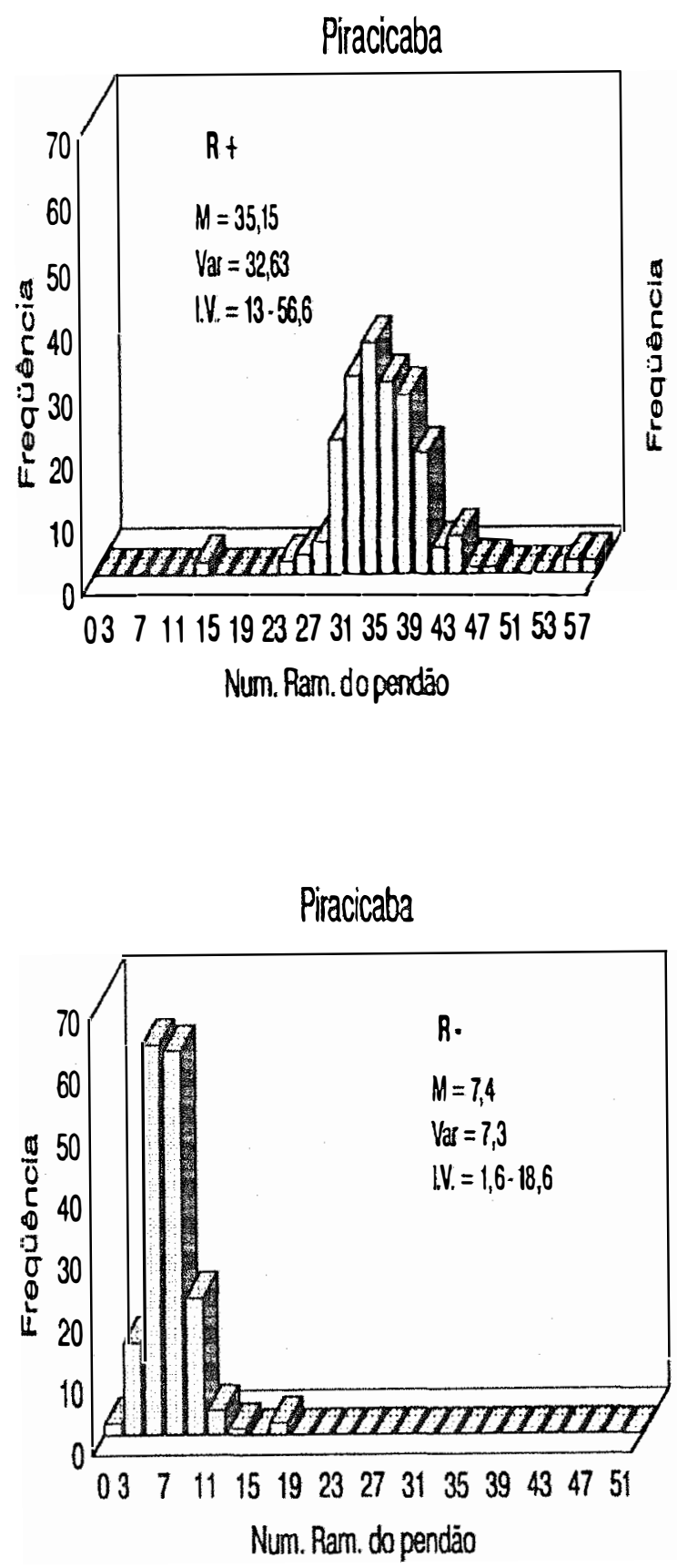
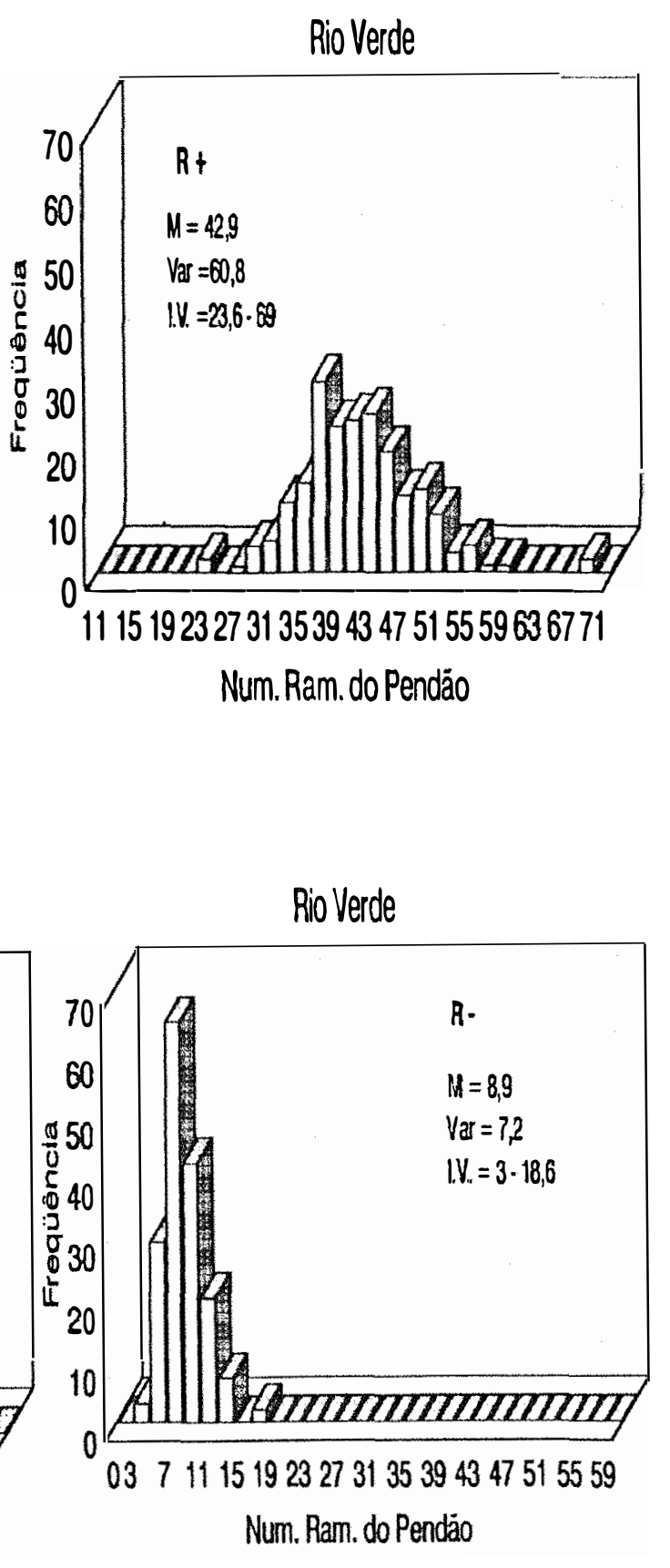

Figura 11 - Dişribuiçāo de frequiência de médias e valores de média populacional ( $M$ ), variância (Var) e intervalo de variaçäo (I.V), para o caráter NR nas subpopulaçöes divergentes paraNR. 

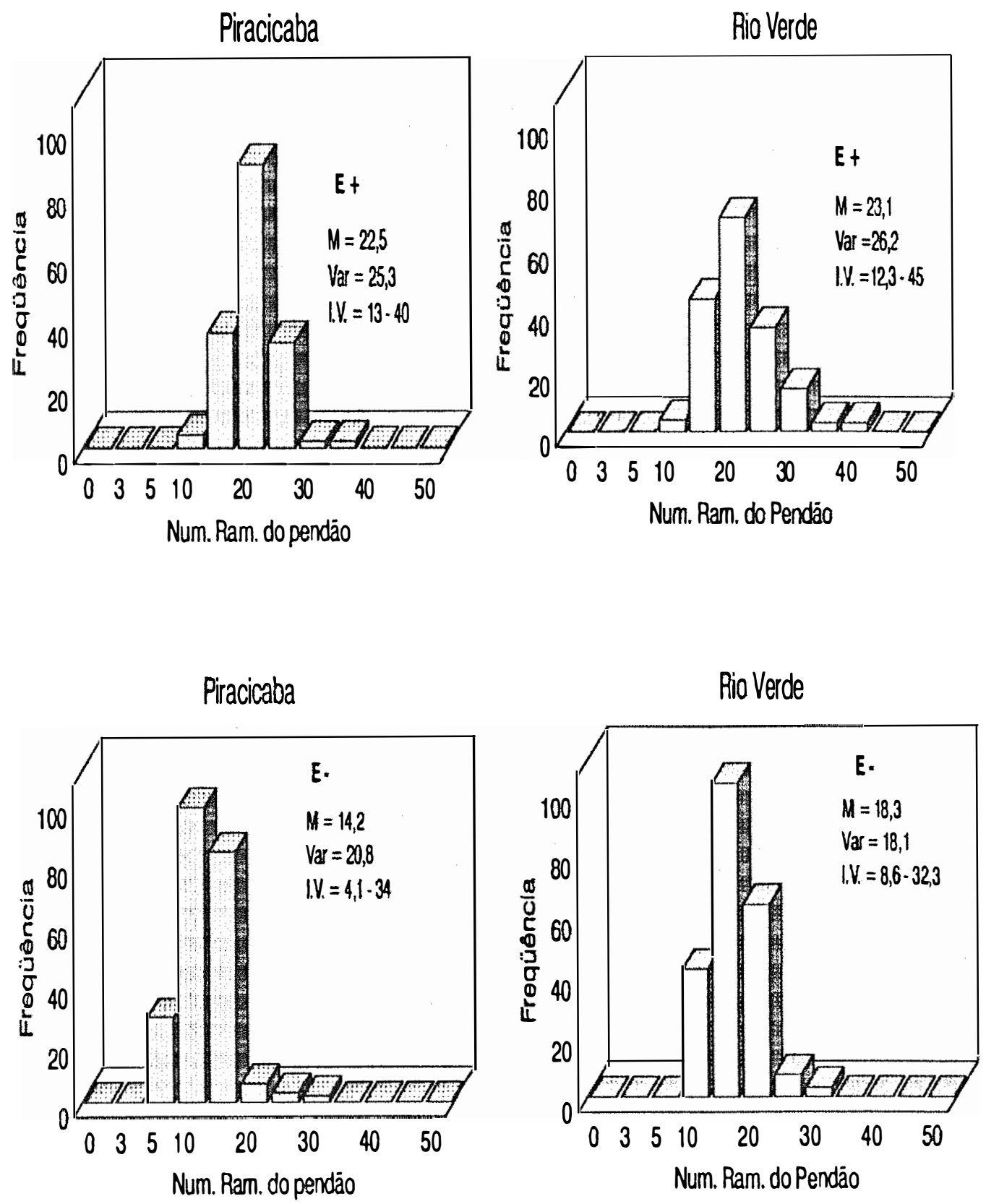

Figura 12 - Distribuição de frequêencia de médias e valores de média populacional ( $M$ ), variância (Var) e intervalo de variação (IIV), para o caráter NR nas subpopulaçōes divergentes para AE. 

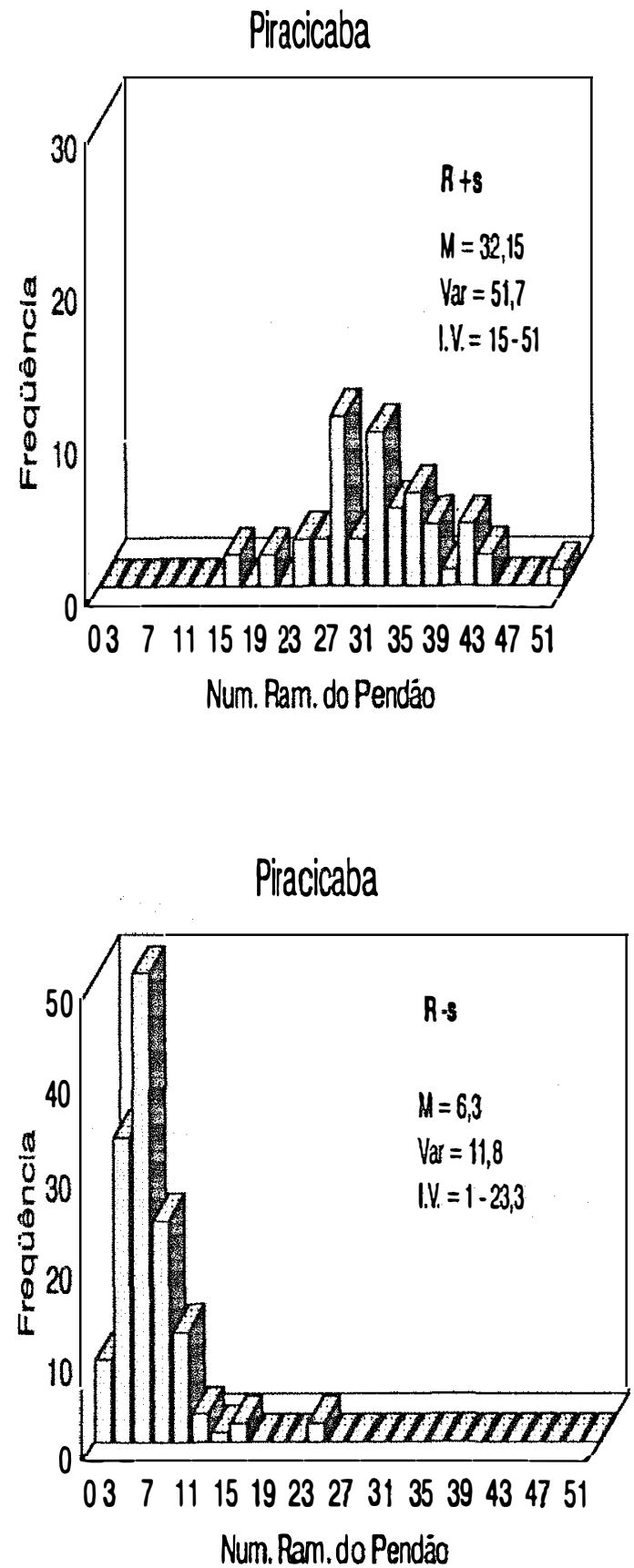

Figura 13 - Distibuiçāo de frequência de médias e valores de média populacional ( $M$ ), variância (Var) e intervalo de variação (IV), para o caráter NR nas subpopulaçöes S1 divergentes para NR. 


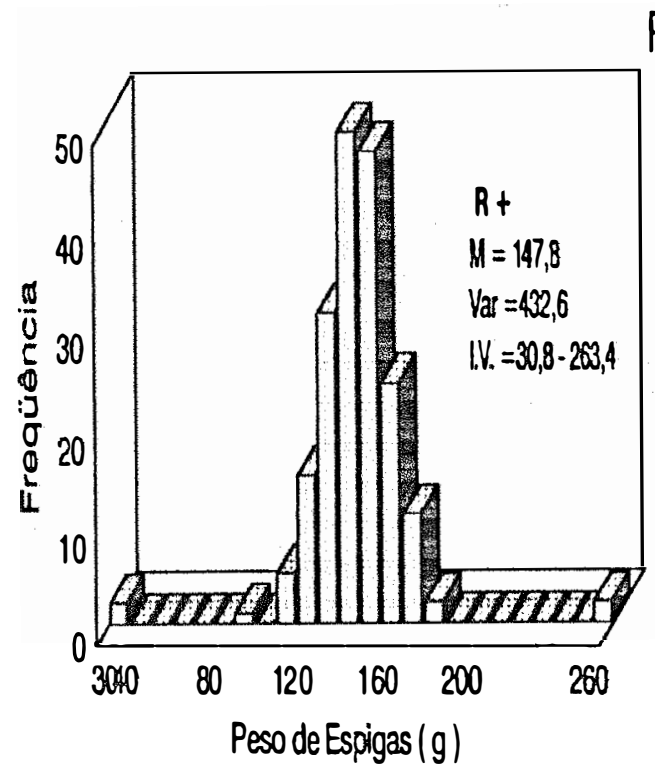

Piracicaba

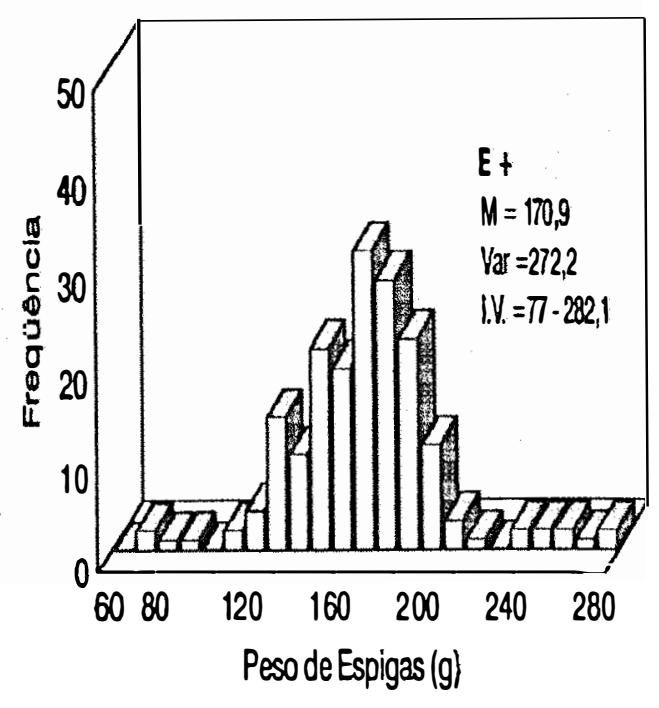

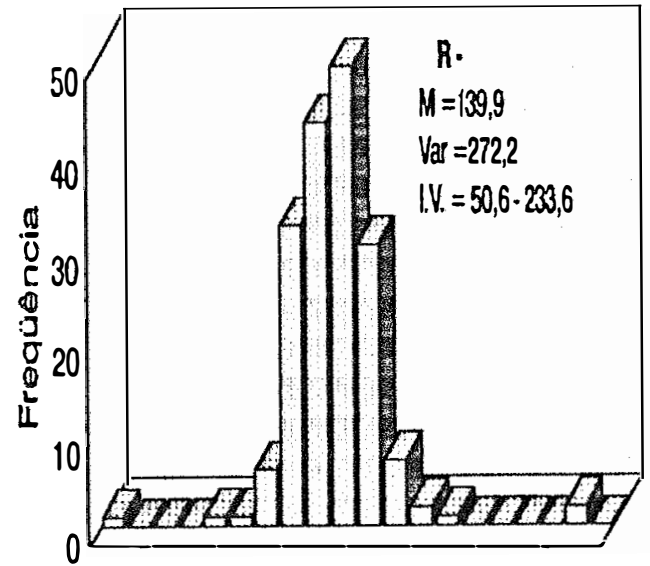

506080100120140160180200220240

Peso de Espigas $(g)$

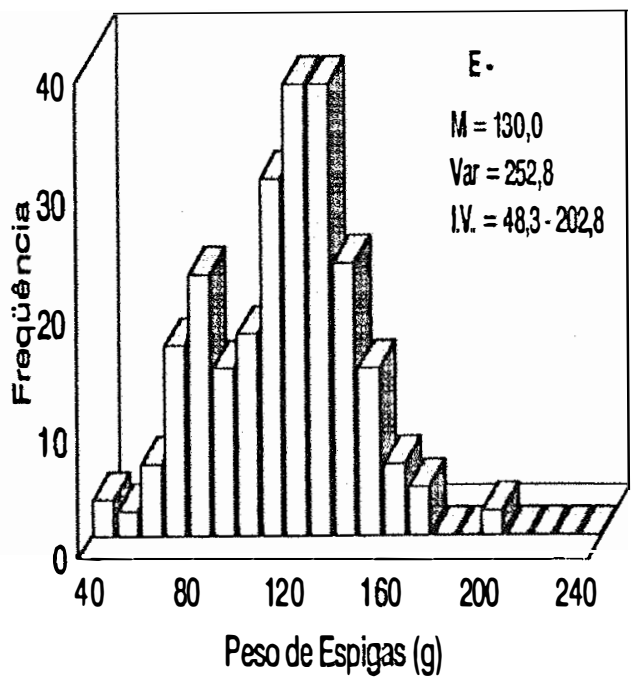

Figura 14 - Distribuiçāo de frequiência de médias evalores de média populacional ( $M$ ), variância (Var) e intervalo de variação (I.V), para o caráter PE nas subpopulaçöes divergentes para NR e AE. 

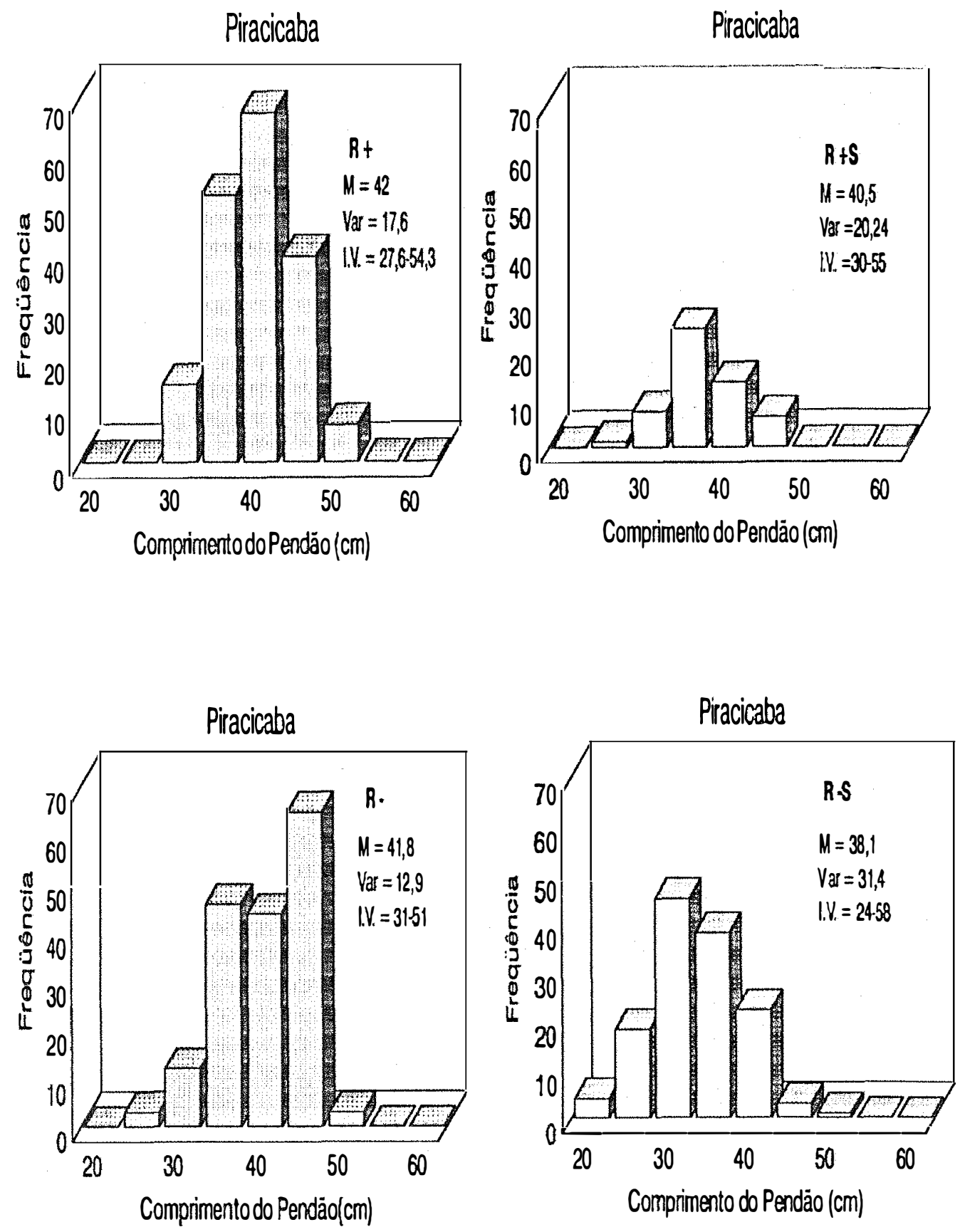

Figura 15 - Distribuição de frequêencia de médias e valores de média populacional (M), variância (Var) e intenvalo de variaçäo (IV), para o caráter CP nas subpopulaçöes divergentes para NR. 


\section{Piracicaba}
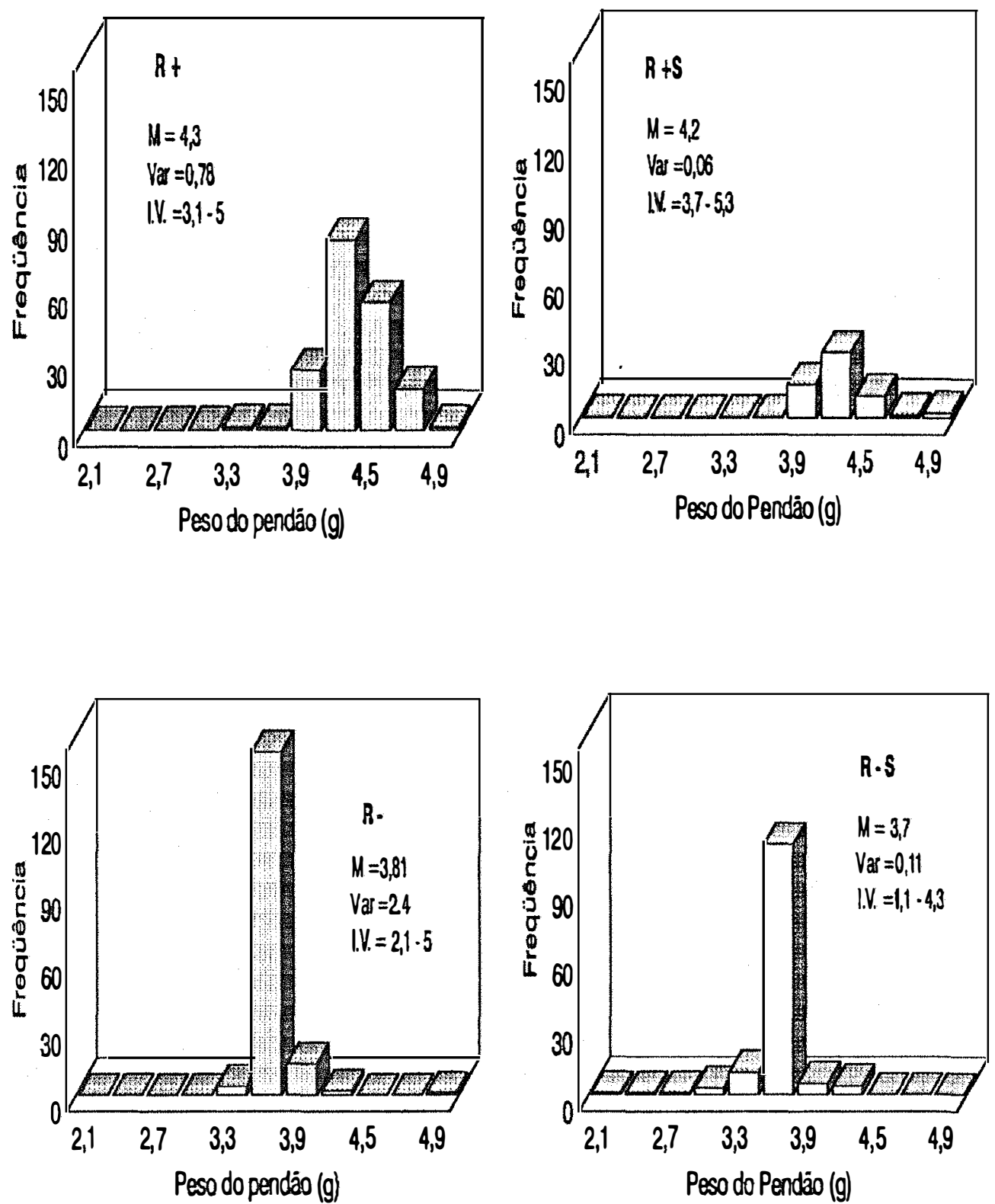

Figura 16 - Distribuiçāo de trequência de médas e valores de média populacional ( $M$ ), variância( Var) e intervalo devariaçäo (IV), para o caráter PP nas subpopulaçöes divergentes para NR. 